\title{
Depressariidae (Lepidoptera) of the Russian Altai Mountains: new species, new records and updated checklist
}

\author{
Peter BUCHNER ${ }^{1)} \&$ Jan ŠUMPICH ${ }^{2)}$ \\ 1) Scheibenstraße 335, A-2625 Schwarzau am Steinfeld, Austria; e-mail: buchner.324@drei.at \\ ${ }^{2)}$ Department of Entomology, National Museum, Cirkusová 1740, CZ-193 00 Praha 9 - Horní Počernice, Czech Republic; \\ e-mail: jansumpich@seznam.cz
}

Accepted:

$20^{\text {th }}$ March 2020

Published online: $30^{\text {th }}$ March 2020

\begin{abstract}
Records of Depressariidae species collected in the Altai Republic (Russia) in 2014-2019 are presented. Agonopterix kyzyltashensis sp. nov., A. ustjuzhanini sp. nov., and Depressaria paraleucocephala sp. nov. are described as new for science. Depressaria leucocephala Snellen, 1884 is deleted from the list of Altaic Depressariidae due its previous confusion with $D$. paraleucocephala sp. nov. Agonopterix rimulella (Caradja, 1920) sp. restit. is removed from synonymy with Agonopterix liturosa (Haworth, 1811). Exaeretia fuscogriseella Hannemann, 1990 syn. nov. is synonymised with E. indubitatella (Hannemann, 1971). Agonopterix feruliphila Millière, 1866 syn. nov. is transferred from synonymy with Agonopterix thapsiella (Zeller, 1847) to synonymy with Agonopterix adspersella (Kollar, 1832). Provisional list of related taxa of the Agonopterix adspersella group is given. Within Russian fauna, Depressaria altaica Zeller, 1854 was presented only from the Altai Republic, namely because the type specimens were recorded in the Altai. However, type locality is the Kazakh Altai, and D. altaica should be removed from checklist of the Altai Republic. At the same time, we present the first reliable records of D. altaica from southern Ural as a new species for Russia. The first reliable record of Agonopterix putridella ([Denis \& Schiffermüller], 1775) for Russia is presented. Exaeretia allisella Stainton, 1849, Agonopterix anticella (Erschoff, 1877), Agonopterix bipunctosa (Curtis, 1850), Agonopterix rimulella, Depressaria sibirella Lvovsky, 1981, D. falkovitshi Lvovsky, 1990, D. libanotidella Schläger, 1848, and D. fuscovirgatella Hannemann, 1967 are new for the Altai Republic. In addition, Exaeretia mongolicella (Christoph, 1882) was found as new for the Tuva Republic. In total, 36 species of the studied family are known from the Altai Republic to date. Figures of all species new for the Altai Republic and the Tuva Republic are presented. Newly described species are figured in detail including their genitalia.
\end{abstract}

Key words. Lepidoptera, Depressariidae, Agonopterix, Depressaria, Exaeretia, Levipalpus, taxonomy, barcoding, cytochrome oxidase I, genetic distances, Ural Mountains, Russia, Palaearctic Region

\section{Introduction}

The family Depressariidae Meyrick, 1883, included in the superfamily Gelechioidea Fracker, 1915, comprises over 550 species in 35 genera distributed worldwide, but the most species occur in the forest zone of the Holarctic Region. In the Palaearctic more than 350 species in 8 genera are known to date (Lvovsky 2016). The study of Russian Depressariidae fauna resulted in 143 recorded species (Lvovsky 2008). Within Russia, Depressariidae fauna of the Altai mountains (formally the Altai Republic) was insufficiently known until recently, namely only 19 species were listed from that area (Lvovsky 2008). Recently, another 10 species were newly recorded, three of them without species level identification (HuEmer et al. 2017). One of these unidentified species, in the paper listed as Depressaria sp., is presented in this paper as Agonopterix 
rimulella (Caradja, 1920). The second one belongs to the Agonopterix putridella/argyrella group and was collected also by us, and the third species, in the mentioned paper listed as Agonopterix sp. 2, is described here as A. ustjuzhanini. In 2019, a new species, Exaeretia lvovskyi Buchner, Junnilainen \& Nupponen, 2019, was described from the Altai (Buchner et al. 2019). This description was based partly on the material collected by the second author in the Altai mountains.

Within Russia, only Agonopterix sinevi Lvovsky, 1984 has been hitherto recorded only in the Altai Republic (Lvovsky 2006) but it cannot be considered endemic for this territory because it was described from Kyrgyzstan (Lvovsky 1984).

The goal of the present paper is to provide new faunistic data for 26 Depressariidae species of which one is new for Russia, eight for the Altai Republic and one for the Tuva Republic, and to describe three new species, one of which seems to be endemic for the Altai Mountains.

\section{Material and methods}

Specimens and photographic documentation. The material presented was collected mainly by the second author using portable light traps (with ultraviolet $8 \mathrm{~W} / 12 \mathrm{~V}$ tubes). Preparations of genitalia slides followed standard techniques (RoBINSON 1976). Male preparations were stained with mercurochrome and females with chlorazol and subsequently examined under a microscope (Wild Heerbrugg) with a $10 \times$ objective and a $2.5 \times$ ocular. Photos of specimens in total view were taken with a Canon EOS 5D Mark III camera and a Canon EF $100 \mathrm{~mm} 2.8$ L IS USM lens at $1: 1$. Specimens were illuminated with two diffused flashes, using a third flash to set the background whiteness. In the descriptions, the terminology for genitalia follows HANNEMANN (1958) and papers of the first author, e.g. Buchner et al. (2019). Most of the photos were edited in Helicon Focus 6.3.5 Pro and Adobe Photoshop CC.The photographs contain the numbers of genitalia preparations or photographed specimens (with prefix "DEEUR") according to which it is possible to find these specimens in the particular collections, various databases or other papers of the first author.

Collections studied for this paper and abbreviations used:

DEEUR "Depressariinae of Europe", prefix for a photo or genitalia slide made by P. Buchner;

gen. prep. genitalia preparation;

ECKU Collection of Ecology-Centre, Kiel University, Kiel, Germany;

IDJC Research collection of Ivo Dvořák, Jihlava, Czech Republic;

LMK Landesmuseum Kärnten, Klagenfurt, Austria;

HNHM Hungarian Natural History Museum, Budapest, Hungary;

MFSN Museo Friulano di Storia Naturale, Udine, Italy;

MGAB "Grigore Antipa" National Museum of Natural History, Bucharest, Romania;

MNHN Muséum National d'Histoire Naturelle, Paris, France;

NHMUK Natural History Museum, London, United Kingdom;

NHMW Naturhistorisches Museum, Wien, Austria;

NMBE Naturhistorisches Museum, Bern, Switzerland;

NMPC National Museum, Prague, Czech Republic;

RCAM Research Collection of Anton Mayr, Feldkirch, Austria;

RCAW Research Collection of Andreas Werno, Nunkirchen, Germany;
RCBZ Research Collection of Boyan Zlatkov, Sofia, Bulgaria;

RCFG Research Collection of Friedmar Graf, Bautzen, Germany;

RCGD Research collection of Georg Derra, Reckendorf, Germany;

RCGF Research Collection of Gyulay Fábián, Budapest, Hungary;

RCHB Research Collection of Hans Blackstein, Germany;

RCHR Research Collection of Hans Retzlaff, Lage, Germany;

RCKL Research Collection of Knud Larsen, Dyssegård, Denmark;

RCKN Research Collection of Kari Nupponen, Espoo, Finland;

RCLK Research Collection of L. P. Kaitila, Finland;

RCLM Research Collection of Lucio Morin, Monfalcone, Italy;

RCLS Research Collection of L'ubomír Srnka, Lehota pod Vtáčnikom, Slovakia;

RCPB Research Collection of Peter Buchner, Schwarzau am Steinfeld, Austria;

RCRD Research Collection of Frédéric Rymarczyk \& Monique Dutheil, Nice, France;

RCRS Research Collection of Rudi Seliger, Schwalmtal, Germany;

RCWS Research Collection of Wolfgang Stark, Trübensee bei Tulln, Austria;

SMNK Staatliches Museum für Naturkunde, Karlsruhe, Germany;

TLMF Tiroler Landesmuseum Ferdinandeum, Innsbruck, Austria;

ZIN Zoological Institute, Russian Academy of Sciences, St. Petersburg, Russia;

ZMHB Museum für Naturkunde der Humboldt-Universität, Berlin, Germany;

ZMUC Zoological Museum, University of Copenhagen, Copenhagen, Denmark;

ZMUH Zoology Museum, University of Helsinki, Helsinki, Finland; ZSM Zoologische Staatssammlung, München, Germany.

DNA barcoding. Selected 69 specimens of all taxa recorded in the Altai Mts. and presented in this study were barcoded at the Canadian Centre for DNA Barcoding (CCDB, Biodiversity Institute of Ontario, University of Guelph). We used dry legs for DNA extraction. Barcode sequences of the mitochondrial COI gene were obtained (a 658 base-pair long segment of the 5' terminus of cytochrome c oxidase I). Details of the sequenced specimens, comprising faunistic data and images, were uploaded to the Barcode of Life Data Systems (BOLD; RATNASINGHAM \& HEBERT 2007) where two public datasets were established. The first one comprises the Altaic records ("DS-DEPRESS2 Depressariidae of Altai", dx.doi. org/10.5883/DS-DEPRESS2), the second one includes the records used for the comparison and assembling of trees ("DS-DEPRESS3 Depressariidae of Altai_Trees 1-4", dx.doi.org/10.5883/DS-DEPRESS3). The newly generated sequences were also submitted to GenBank under the accession numbers MN968402-MN968491 and MN942267-MN942334. Only 400 bp long or longer sequences were downloaded from BOLD using implemented Muscle multiple alignment algorithm (EDGAR 2004) and subsequently edited and analyzed in MEGA X software (KUMAR et al. 2018). Tamura 3-parameter model (TAMURA 1992) with uniform rates was suggested as the best model for the data and it was used during the calculations of genetic distances and phylogenetic trees. Maximum likelihood computation method was used including 1000 bootstrap replications for each tree. For each species we present the Barcode Index Numbers (BIN) (RAtnasingham \& Hebert 2013) and compare the results obtained from the Altaic moths with public and partly private data from other regions stored in the BOLD database. 


\section{Recorded species}

\section{Family Depressariidae Meyrick, 1883}

We follow the conclusions of HEIKKILÄ et al. (2014) and SoHn et al. (2015) concerning the placement of Depressariidae in rank of a separate family.

\section{Levipalpus hepatariella (Lienig \& Zeller, 1846)}

Material examined. RUSSIA: Altai Republic: Belyashi env. (56 km $\mathrm{SE})$, Dzhazator valley, $49^{\circ} 38^{\prime} \mathrm{N}, 88^{\circ} 12^{\prime} \mathrm{E}$, mountain meadows near Tara river, $2300 \mathrm{~m}$, 25.-26.vii.2017, 4 ๙ึฎ (Barcode NMPC-LEP-0148), J. Šumpich leg.; Belyashi (Dzhazator) env. (25 km NW), confluence of Argut and Karagem rivers, $49^{\circ} 51^{\prime} 56^{\prime \prime} \mathrm{N}, 87^{\circ} 10^{\prime} 22^{\prime \prime} \mathrm{E}$, rocky steppe, 1400

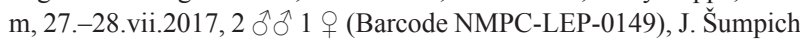
leg. (all NMPC).

Molecular data. BIN BOLD: AAJ2744 ( $\mathrm{n}=21 ; 17$ public, 7 from Altai). The average intraspecific divergence of the barcode region is $0.42 \%$ (maximum $0.96 \%$ ). Barcoded specimens are ordered in two distinct clusters where all Altaic specimens are clustered together with Finnish specimens. Distribution. Palaearctic. From the Altai first published by Huemer et al. (2017).

\section{Exaeretia allisella Stainton, 1849 (Figs 1-7)}

Material examined. RUSSIA: Altai Republic: Belyashi (Dzhazator) env. ( $25 \mathrm{~km} \mathrm{NW}$ ), confluence of Argut and Karagem rivers, 49 $51^{\prime} 56^{\prime \prime} \mathrm{N}$, $87^{\circ} 10^{\prime} 22^{\prime \prime} \mathrm{E}$, rocky steppe, $1400 \mathrm{~m}, 27 .-28 . v i i .2017,1$ (Barcode NMPC-LEP-0166), J. Šumpich leg. (NMPC); Shebalino Distr., Cherga vill. $(8 \mathrm{~km} \mathrm{~W}), 51^{\circ} 34^{\prime} 04^{\prime \prime} \mathrm{N}, 85^{\circ} 28^{\prime} 33^{\prime \prime} \mathrm{E}$, rocky slopes, steppe, $580 \mathrm{~m}, 8 .-9$. vii.2019, 1 ઈ 1 ค , J. Šumpich leg. (NMPC).

Molecular data. BIN BOLD: ABA0482 $(\mathrm{n}=2,2$ public, 1 from Altai); BIN BOLD: AAD3659 $(\mathrm{n}=9,9$ public, 0 from Altai). The distance of the cluster with the specimens from the Altai and Switzerland (BOLD: ABA0482) from the second one with north European specimens is 3.41\%. That is the reason why BOLD automatically created two BINs. However, we did not find any noticeable differences in habitus and genitalia compared with European specimens. Therefore we classify all specimens as one species where the maximum intraspecific divergence of the barcode region reaches $3.56 \%$.

Distribution. Palaearctic, absent in southern Europe. In Russia widely distributed but not previously recorded from the Altai Mountains (Lvovsky 2008, 2013). The first record for the Altai Republic.

Remark. Exaeretia liupanshana Liu \& Wang, 2010 was described from Mt. Liupan, Ningxia Huizu Autonomous Region, in China. This species is indistinguishable in habitus and male genitalia from E. allisella; the main difference was presented primarily in the size of signum in female (LiU \& WANG 2010). However, we examined four females collected at the same place in Switzerland (Ardez, Graubünden) and found high variability in this character (Figs 5-6). The occurrence of two different closely related species in such a small area is highly unlikely. Our provisional conclusion therefore is that the difference in the size of signum falls within the intraspecific variability, and E. liupanshana should be synonymised with E. allisella.
Unfortunately, we have insufficient specimens named $E$. liupanshana and no type material available for detailed comparison. For this reason we do not propose this synonymy in this paper.

\section{Exaeretia indubitatella (Hannemann, 1971)}

(Figs 8-17)

= Exaeretia fuscogriseella Hannemann, 1990 syn. nov.

Material examined. RUSSIA: Altai RePUBLIC: Kosh-Agach Distr., Ukok plateau, 18.vii.2001, 1 ઈิ (photo DEEUR 4538 P. Buchner), (Barcode TLMF Lep 19275), A. Bidzilya leg.; Belyashi (Dzhazator) env. (25 km $\mathrm{NW}$ ), confluence of Argut and Karagem rivers, 49 $51^{\prime} 56^{\prime \prime} \mathrm{N}, 87^{\circ} 10^{\prime} 22^{\prime \prime} \mathrm{E}$, rocky steppe, $1400 \mathrm{~m}, 27 .-28 . v i i .2017,10 \hat{\jmath}$, J. Šumpich leg. (NMPC); Belyashi env. (56 km SE), Dzhazator valley, $49^{\circ} 38^{\prime} \mathrm{N}, 88^{\circ} 12^{\prime} \mathrm{E}$, mountain

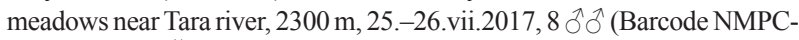
-LEP-0150), J. Šumpich leg. (NMPC); Kosh-Agach Distr., Kurai env. (6.5 $\mathrm{km} \mathrm{SW}), 50^{\circ} 10^{\prime} 35^{\prime \prime} \mathrm{N}, 87^{\circ} 53^{\prime} 55^{\prime \prime} \mathrm{E}$, grassy steppe, $1550 \mathrm{~m}$, 30.vii.2017,

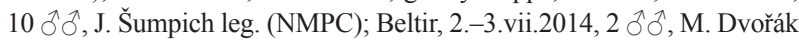
leg. (NMPC); Kosh-Agach Distr., Chagan-Uzun env., Krasnaya Gorka hill, $50^{\circ} 05^{\prime} 00^{\prime \prime} \mathrm{N}, 88^{\circ} 25^{\prime} 15^{\prime \prime} \mathrm{E}$, rocky steppe, $1870 \mathrm{~m}, 23$.vii.2017, $1 \stackrel{\jmath}{\jmath}$, J. Sumpich leg. (NMPC). Tuva: $75 \mathrm{~km}$ NE of Kosh-Agach, Ak-Chol lake, $50^{\circ} 16^{\prime} 43^{\prime \prime} \mathrm{N}, 89^{\circ} 36^{\prime} 44^{\prime \prime} \mathrm{E}$, rocky steppe, meadows, $2230 \mathrm{~m}$, 2.-3.vii.2015, $14 \hat{\jmath} \widehat{\jmath}$ (gen. prep. DEEUR 6228 P. Buchner), (Barcode TLMF Lep 23319), J. Šumpich \& M. Dvořák leg. (NMPC).

Molecular data. BIN BOLD: $\operatorname{ADF} 0702(\mathrm{n}=2,1$ public, 1 from Altai); BIN BOLD: ACS7483 ( $\mathrm{n}=14,1$ public, 5 from Altai, 1 from Tuva). The distance of the only public Altaic specimen in the first cluster (BOLD: ADF0702) (Fig. 10) from the specimens in the second cluster (BOLD: ACS7483) (Fig. 8) is $4.12 \%$ on average (maximum $4.70 \%$ ), and that is why BOLD automatically assigned two BINs. The average intraspecific divergence of the barcode region within the second cluster (BOLD: ACS7483) is only $0.82 \%$ (maximum $1.77 \%$ ). Despite this difference in barcodes we did not find any difference in the genitalia, and therefore we classify all specimens as one species with the maximum intraspecific divergence of the barcode region of $4.70 \%$.

Distribution. Russia, Mongolia, Afghanistan (Lvovsky 2013, LiU \& WANG 2010). In Russia distributed only in southern Siberia. From the Altai first reported (without faunistic details) by Lvovsky (2006) as E. fuscogriseella, and by Lvovsky (2013) as E. indubitatella. The first exact faunistic records from the Altai were subsequently published by Huemer et al. (2017). Records from China (Inner Mongolia) published by LIU \& WANG (2010) most probably belong to Exaeretia kozhantshikovi Lvovsky, 2013, whose characteristic features of the forewings fully fit with the specimen photos presented in this paper. Also, the records from the Far East published as E. indubitatella (LVOVSKY 2008) actually belong to this species (cf. LvOvSKY 2013). Remark. Exaeretia indubitatella was described based on two specimens from Mongolia (12.viii.1965, Z. Kaszab leg., HNHM). In the description, the oblique black streak in $\mathrm{R}-\mathrm{Cu}$ cell is highlighted. Male genitalia are compared with those of E. stramentella (Eversmann, 1844) [=E. culcitella (Herrich-Schäffer, 1854)], which are in fact very similar; female genitalia were unknown to Hannemann.

Exaeretia fuscogriseella was described based on one male from Mongolia (without date, ex coll. C. S. Larsen, ZMUC) (Figs 11, 15). In the description, the presence 


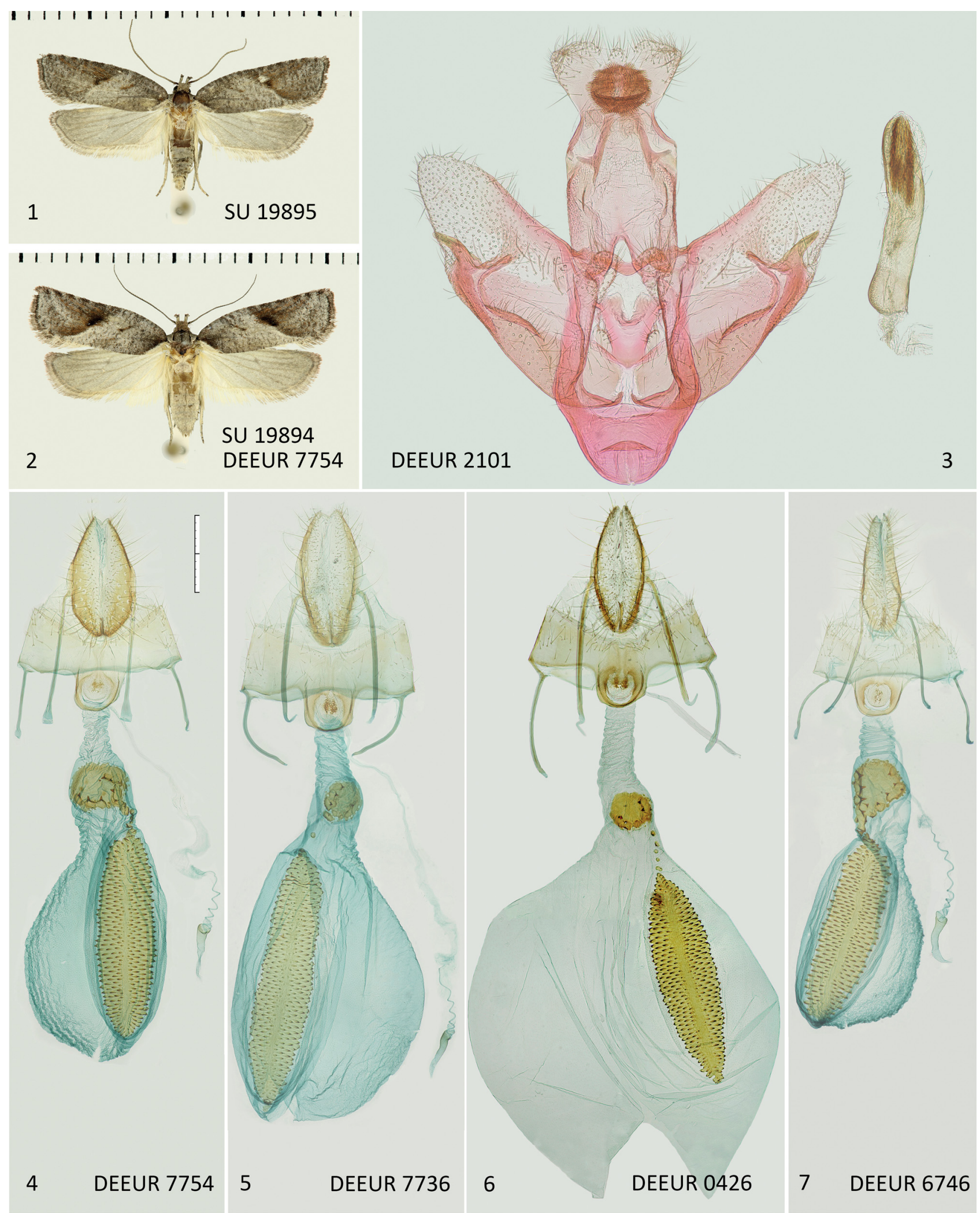

Figs 1-7. Exaeretia allisella Stainton, 1849. 1-2 - Russia, Altai, Cherga, 8.-9.vii.2019, J. Šumpich leg. (NMPC): 1 - male; 2 - female; 3 - male genitalia, Denmark, Jylland, Glatved, 3.viii.1973, E. S. Nielsen leg. (TLMF). 4-7 - female genitalia compared to show intraspecific variability $($ scale bar $=1.0$ mm for all slides): 4 - Russia, Altai, Cherga, 8.-9.vii.2019, J. Šumpich leg. (NMPC); 6-7 - Switzerland, Graubunden, Ardez, 17.viii.2005, P. Sonderegger leg. (NMBE); 7 - Russia, Primorsky krai, Khasanskiy Region, Mramorny, 12.viii.2012, K. Larsen leg. (RCKL). 

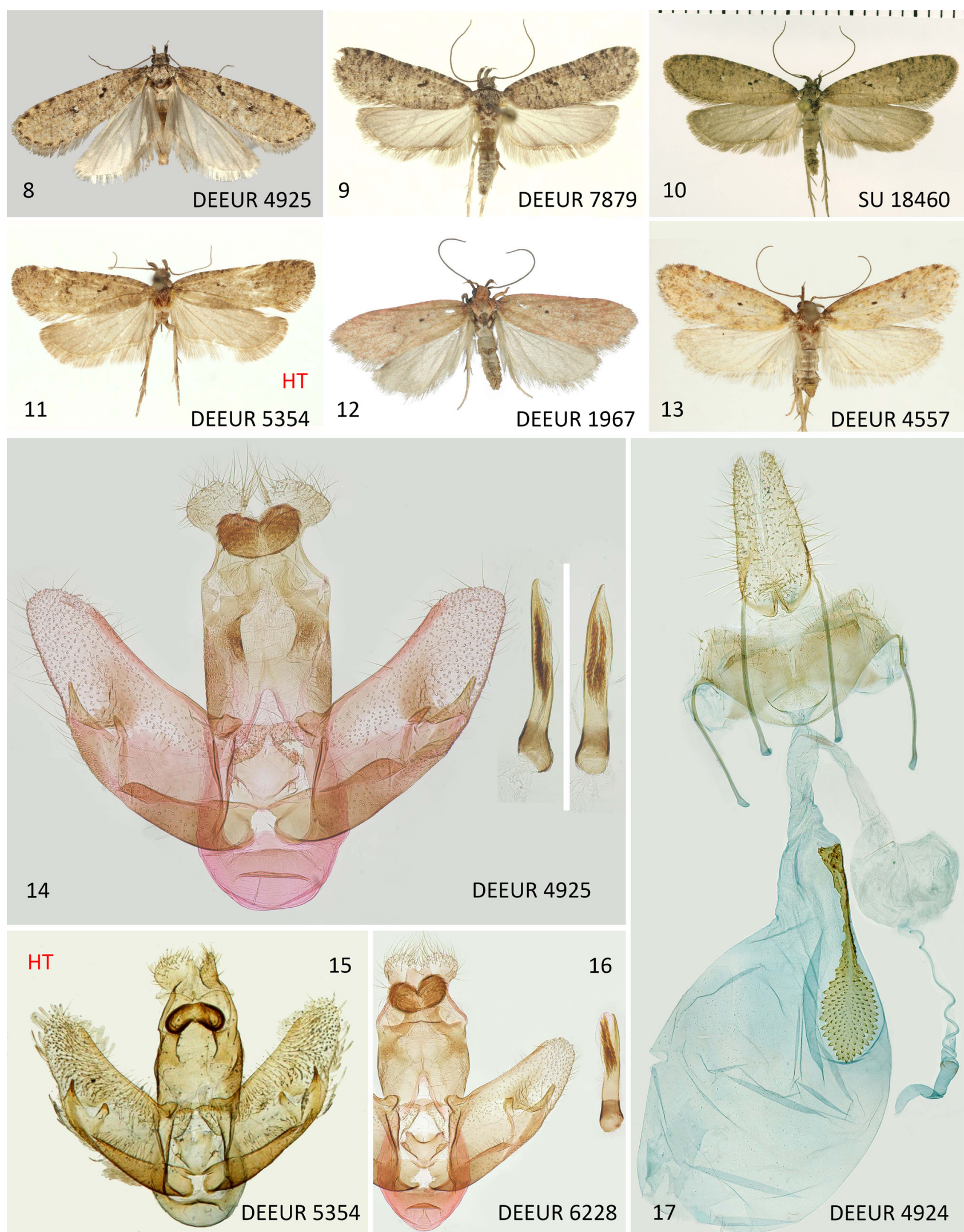

17

DEEUR 4924

Figs 8-17. Exaeretia indubitatella (Hannemann, 1971). 8-13 - variability of males: 8 - Russia, Altai Mts., Tabazhok River, 4.viii.2016, P. Huemer \& B. Wiesmair leg. (TLMF); 9 - Russia, Altai Mts., Dzhazator, the confluence of Argut and Karagem rivers, 27.-28.vii.2017, J. Šumpich leg. (NMPC); 10 Russia, Altai Mts., Dzhazator, Tara River, 25.-26.vii.2017, J. Šumpich leg. (NMPC); 11 - Mongolia, Sayan Mts., Arasagun-gol (ZMUC) (holotype of $E$. fuscogriseella Hannemann, 1990) (museum id. Hannemann Gu4885); 12 - Russia, Altai Mts., Seminskiy Pass, 6.vii.2013, H. Blackstein leg. (RCHB); 13 - Russia, S Ural, Amurskii vill., Arkaim Reserve, K. Nupponen leg. (RCKN). 14-16-male genitalia: 14 - data as fig. 8; 15 - data as fig. 11 (holotype of E. fuscogriseella); 16 - Russia, Tuva, Ak-chol lake, 3.vii.2015, M. Dvořák leg. (NMPC); 17 - female genitalia, data as fig. 8. 


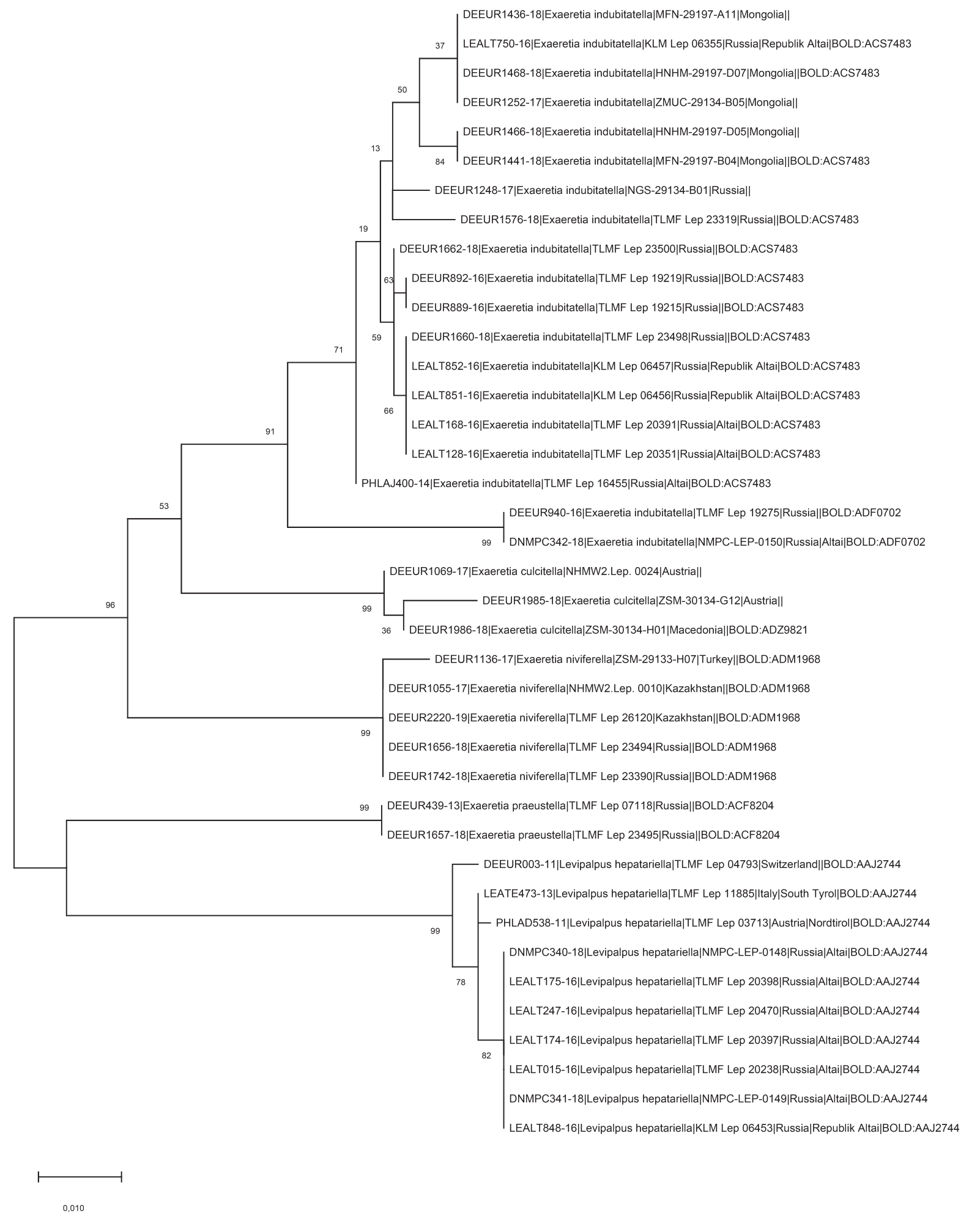

Fig. 18. Maximum likelihood tree of Exaeretia indubitatella (Hannemann, 1971) and the related taxa with Levipalpus hepatariella (Lienig \& Zeller, 1846 ) as an outgroup species (data from BOLD).

of two black dots in $\mathrm{R}-\mathrm{Cu}$ cell is mentioned. There is no comparison of E. fuscogriseella with E. indubitatella, only with E. niviferella (Christoph, 1872), which is difficult to understand, because $E$. indubitatella is much more similar both in genitalia and external appearance. It is likely that when Hannemann was describing E. fuscogriseella, he forgot to compare it with $E$. indubitatella, otherwise the description of $E$. fuscogriseella would never have occurred. Comparison of more specimens of E. indubitatella show distinctly larger variability in external appearance than the differences between the holotypes of $E$. indubitatella and E. fuscogriseella. The same situation was found in male genitalia (Figs 14-16), but without the correlation between the external and genitalia differences, which is a clear indication of conspecifity, and thus we synonymise E. fuscogriseella with E. indubitatella. Barcode results also confirm this conclusion. Holotypes of E. indubitatella and E. fuscogriseella were successfully sequenced according 
to the NGS-protocol, and considering the age of these specimens with relatively good results: the holotype of $E$. indubitatella with 658[89n] bp long sequence, and the more than 100 year old holotype of E. fuscogriseella brought a $325[50 \mathrm{n}]$ bp sequence, both enough to show that at least this part of the barcode region is identical (Fig. 18).

\section{Exaeretia lepidella (Christoph, 1872)}

Material examined. RUSSIA: Altai Republic: Aktash vill., $50^{\circ} 19^{\prime} 12^{\prime \prime} \mathrm{N}, 87^{\circ} 36^{\prime} 00^{\prime \prime} \mathrm{E}$, grassy steppe, rocks, $1400 \mathrm{~m}, 21 . v i .2015,3$

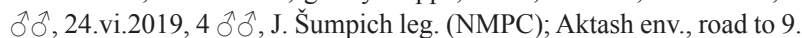
station (below “Zavod"), 50 19'14"N, 8742'57"E, mountain meadows, 2260 m, 22.-23.vi.2015, 1 ô (gen. slide DEEUR 6172 P. Buchner), (Barcode TLMF Lep 23282), J. Šumpich leg. (NMPC); Kosh-Agach Distr., Kurai env. (15 km SW), Dzhangyskol lake, 50¹0'49"N, 8744'19"E, coniferous forest/steppe, $1830 \mathrm{~m}, 24 .-25 . v i .2015,1$ Jै, J. Sumpich leg. (NMPC); Kosh-Agach Distr., Kurai env. (6.5 km SW), $50^{\circ} 10^{\prime} 35^{\prime \prime} \mathrm{N}$,

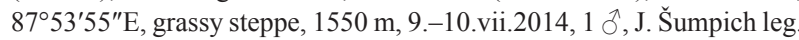
(NMPC); Kosh-Agach Distr., Kurai env. (15 km SW), Dzhangyskol lake, $50^{\circ} 10^{\prime} 49^{\prime \prime} \mathrm{N}, 87^{\circ} 44^{\prime} 19^{\prime \prime} \mathrm{E}$, steppe, $1830 \mathrm{~m}, 7 \jmath^{\jmath} \widehat{\partial}$, J. Šumpich leg. (NMPC).

Molecular data. BIN BOLD: ACX7885 $(\mathrm{n}=5,1$ public, 2 from Altai). E. lepidella and E. nebulosella (Caradja, 1920) are not distinguishable in their barcodes, and therefore BOLD generated only one BIN for both taxa. However, the two species differ highly in habitus. The average intraspecific divergence of the barcode regions of both taxa is $0.27 \%$ (maximum $0.48 \%$ ).
Distribution. Russia, Kazakhstan, Mongolia (LvovsKy 2013).

\section{Exaeretia lvovskyi \\ Buchner, Junnilainen \& Nupponen, 2019}

Material examined. RUSSIA: ALtaI REPUBLIC: Aktash vill., 50 $0^{\circ} 19^{\prime} 12^{\prime \prime} \mathrm{N}$, $87^{\circ} 36^{\prime} 00^{\prime \prime} \mathrm{E}$, grassy steppe, rocks, $1400 \mathrm{~m}$, 24.vi.2019, 1 ô, J. Šumpich leg. (NMPC); Chulyshman valley, $45 \mathrm{~km} \mathrm{~N}$ of Ulagan vill., $51^{\circ} 01^{\prime} 03^{\prime \prime} \mathrm{N}$, $88^{\circ} 00^{\prime} 39^{\prime \prime}$ E, grassy steppe, rocks, $600 \mathrm{~m}, 26 .-27 . v i .2019,1$ đ, J. Šumpich leg. (NMPC); Kosh-Agach Distr., Chagan-Uzun env., Krasnaya Gorka hill, $50^{\circ} 05^{\prime} 00^{\prime \prime} \mathrm{N}, 88^{\circ} 25^{\prime} 15^{\prime \prime} \mathrm{E}$, rocky steppe, $1870 \mathrm{~m}, 1$.-3.vii.2019, 11 ठठ 2 우우, J. Šumpich leg. (NMPC).

Molecular data. BIN BOLD: ADC5991 ( $\mathrm{n}=6$; 3 public, 4 from Altai). The average intraspecific divergence of the barcode region is $0.19 \%$ (maximum $0.32 \%$ ). Distribution. Russia (Southern Ural, Altai Mts., Buryatia) (BuCHNER et al. 2019).

Remark. The species description is partly based on the specimens collected in the Altai Mts. by the second author in 2015.

\section{Exaeretia mongolicella (Christoph, 1882) (Figs 19-22)}

Material examined. RUSSIA: Tuva: Ak-Chol lake, $75 \mathrm{~km}$ NE of Kosh-Agach, $50^{\circ} 16^{\prime} 43^{\prime \prime} \mathrm{N}, 89^{\circ} 36^{\prime} 44^{\prime \prime} \mathrm{E}$, rocky steppe, meadows, $2230 \mathrm{~m}$,

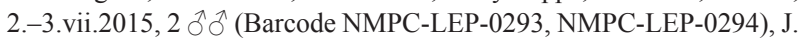
Sumpich leg. (NMPC).
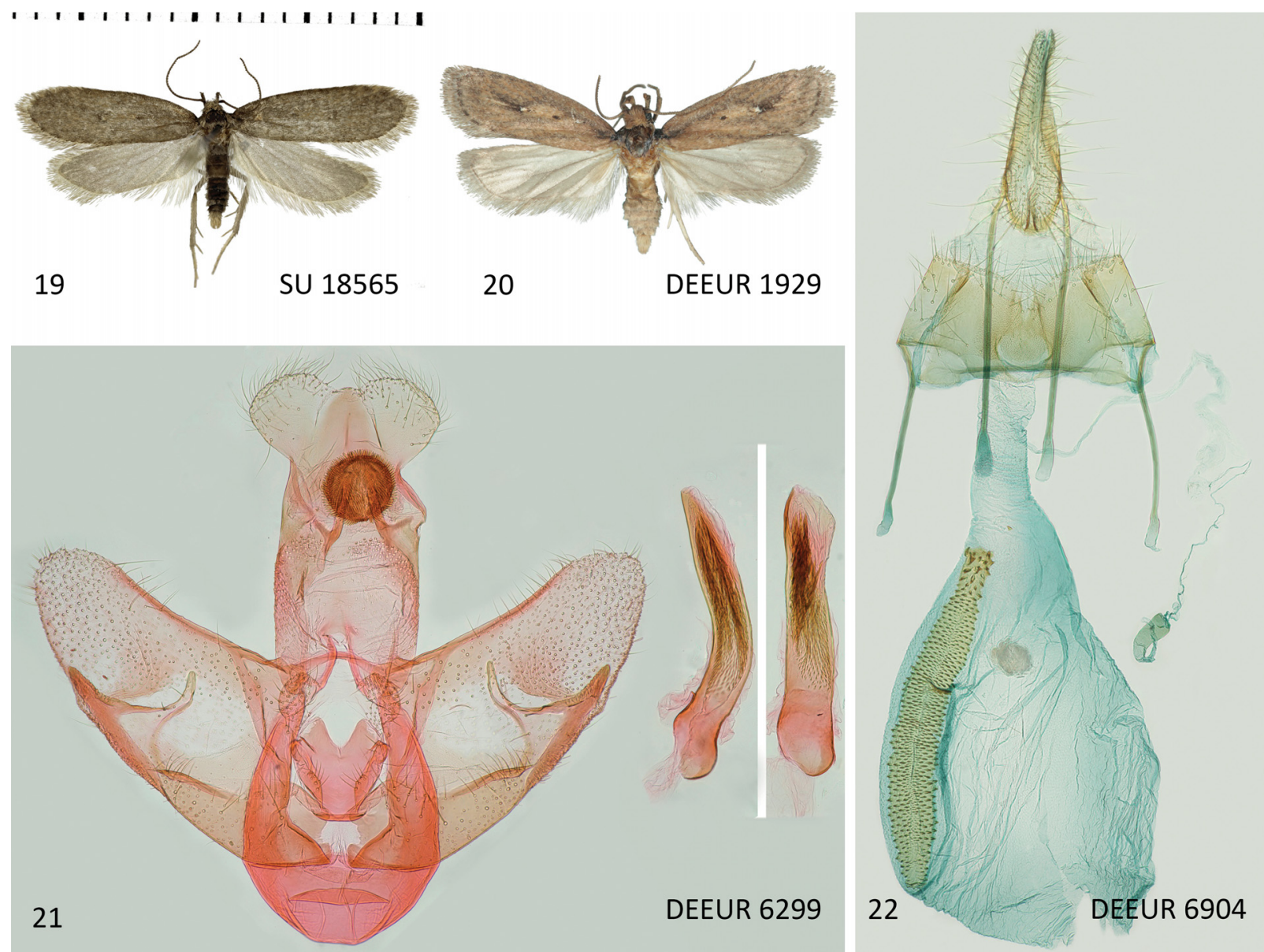

Figs 19-22. Exaeretia mongolicella (Christoph, 1882). 19-20 - habitus: 19- Russia, Tuva, Ak-Chol, Ak-chol lake, 3.vii.2015, J. Šumpich leg. (NMPC); 20 - Russia, Vladivostok, vi.1994, Kuznetsov leg. (RCGD). 21 - male genitalia, Russia, Primorsky krai, Ussuri, Kazakevich, 1908, T. Walsingham leg. (MGAB). 22 - female genitalia, Mongolia, Central Aimak, Kerulen, 24.viii.1965, Z. Kaszab leg. (MNHN) (museum id. EL62902 with slide number MNHN-EL41). 
Molecular data. BIN BOLD: ACX8837 $(n=6 ; 3$ public, 1 from Altai, 2 from Tuva). The average intraspecific divergence of the barcode region is $0.73 \%$ (maximum $1.77 \%$ ). Distribution. Palaearctic. In Europe present in Lithuania and Poland, from where it was described as E. leucostictellus (Rebel, 1917). In Russia it occurs east of the Altai (LvovsKy 2013), the only records from the Altai Republic (Kosh-Agach: Ukok plateau) were published by BIDZILYA et al. (2002). The first record for the Tuva Republic.

\section{Agonopterix abditella Hannemann, 1959 \\ (Figs 23-24)}

Material examined. RUSSIA: Altai Republic: Kosh-Agach Distr., Chagan-Uzun env., Krasnaya Gorka hill, $50^{\circ} 05^{\prime} 00^{\prime \prime} \mathrm{N}, 88^{\circ} 25^{\prime} 15^{\prime \prime} \mathrm{E}$, rocky steppe, 1870 m, 4.vii.2014, 3 $\lesssim$ (Barcodes TLMF Lep 23320, TLMF Lep 23321), M. Dvořák leg. (NMPC); the same locality but 29.vi.2015, 1 đ, M. Dvořák leg. (NMPC); the same locality but 29.vii.2019, 1 o, J. Šumpich leg. (NMPC); Kosh-Agach Distr., Kurai env. (6.5 km SW),

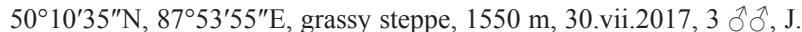
Šumpich leg. (NMPC); Belyashi env. (56 km SE), Dzhazator valley, $49^{\circ} 38^{\prime} \mathrm{N}, 88^{\circ} 12^{\prime} \mathrm{E}$, mountain meadows near Tara river, $2300 \mathrm{~m}, 25 .-26$. vii.2017, $3 \hat{\jmath} \delta$, J. Šumpich leg. (NMPC).

Molecular data. BIN BOLD: ADD9911 $(\mathrm{n}=5$; 4 public, 4 from Altai). The average intraspecific divergence of the barcode region is $0.19 \%$ (maximum $0.49 \%$ ).

Distribution. Russia, Turkey (Lvovsky 2006). In Russia
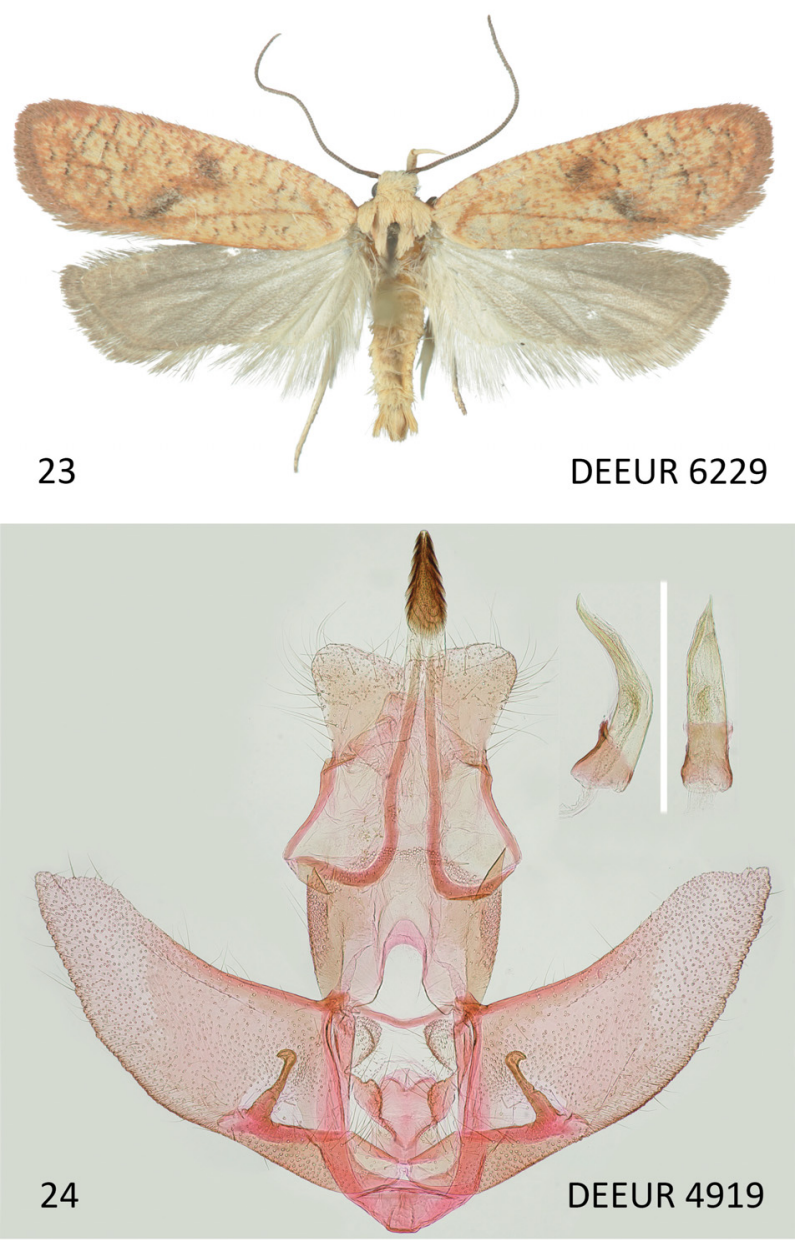

Figs 23-24. Agonopterix abditella Hannemann, 1959. 23 - Russia, Altai Mts., Kosh Agach, Krasnaya Gorka, 4.vii.2014, M. Dvořák leg. (NMPC); 24 - Russia, Altai Mts., Kosh Agach, Tabazhok River, 2100 m, 4.viii.2016, P. Huemer \& B. Wiesmair leg. (TLMF). recently only in the European parts, but in 2016 found in the Altai Mountains as well (HuEmer et al. 2017).

\section{Agonopterix agyrella (Rebel, 1917) (Figs 25-29)}

Material examined. RUSSIA: Altai Republic: Kosh-Agach Distr., Kurai env. (6.5 km SW), $50^{\circ} 10^{\prime} 35^{\prime \prime} \mathrm{N}, 87^{\circ} 53^{\prime} 55^{\prime \prime} \mathrm{E}$, grassy steppe, 1550 m, 30.vii.2017, 1 ठิ (gen. prep. DEEUR 7669 P. Buchner), (Barcode NMPC-LEP-0154), J. Šumpich leg. (NMPC); Belyashi (Dzhazator) env. ( $25 \mathrm{~km} \mathrm{NW})$, confluence of Argut and Karagem rivers, $49^{\circ} 51^{\prime} 56^{\prime \prime} \mathrm{N}$, $87^{\circ} 10^{\prime} 22^{\prime \prime}$ E, rocky steppe, $1400 \mathrm{~m}, 27$. -28.vii.2017, 1 q (Barcode NMPC-LEP-0156), J. Šumpich leg. (NMPC); Katun Valley, $51^{\circ} 40^{\prime} \mathrm{N}, 85^{\circ} 45^{\prime} \mathrm{E}$, 600 m, 1.vii.2001, 1 đ̊ (DEEUR 6456), K. Nupponen leg. (RCKN).

Molecular data. BIN BOLD: AAF7185 ( $n=25$; 10 public, 3 from Altai). The average intraspecific divergence of the barcode region is $0.44 \%$ (maximum $1.29 \%$ ). However, this BIN is shared also with Agonopterix putridella (Denis \& Schiffermuller, 1775), A. septicella Snellen, 1884 and several hitherto unidentified Agonopterix specimens from the $A$. putridella/agyrella group, where all Altaic $A$. agyrella records are clustered with no variability in barcodes. Distribution. Asian part of Russia (Novosibirsk Region, Altai, Primorsky krai), Mongolia, China (Lvovsky 2006). From the Russian Altai this species was also published by Huemer et al. (2017) as Agonopterix sp. 1.

Remarks. Agonopterix agyrella was described based on a single male from eastern Tannu-Ola mountains in southern Siberia in Russia (Figs 27, 29). This holotype was successfully barcoded by the NGS method (sample ID NHMW2.Lep. 0001) where all three Altaic specimens have $100 \%$ match with its barcode. These three specimens also correspond with the type of A. agyrella in genitalia and external appearance, which confirms their conspecificity (Figs 28-29). On the other hand, the intraspecific variability of $A$. agyrella is poorly known, and although it differs in external appearance from the related taxa very well, it is possible to expect taxonomic changes in the $A$. putridella/agyrella species group in the future. Barcoding of the specimen from Katun Valley (DEEUR 6456 P. Buchner) failed, therefore its identification based only on the characters in genitalia must be considered provisional for the moment.

\section{Agonopterix angelicella (Hübner, [1813])}

Material examined. RUSSIA: Altai RePublic: Belyashi (Dzhazator) env. (25 km NW), confluence of Argut and Karagem rivers, 49 $51^{\prime} 56^{\prime \prime} \mathrm{N}$, $87^{\circ} 10^{\prime} 22^{\prime \prime} \mathrm{E}$, rocky steppe, $1400 \mathrm{~m}, 27 .-28 . v i i .2017,1$ 우 1 (Barcode NMPC-LEP-0155, NMPC-LEP-0157), J. Šumpich leg. (NMPC).

Molecular data. BIN BOLD: AAE3381 ( $\mathrm{n}=54 ; 47$ public, 3 from Altai). The average intraspecific divergence of the barcode region is $0.37 \%$ (maximum $1.01 \%)$. For this species, BOLD established also BIN BOLD: ABZ4758 $(\mathrm{n}=5)$ and BIN BOLD: ACZ3339 $(n=1)$, where the average intraspecific divergence of the barcode region between BOLD: AAE3381 and BOLD: ABZ4758 is $2.21 \%$, between BOLD: AAE3381 and BOLD: ACZ3339 2.07\%, and between BOLD: ABZ4758 and BOLD: AAE3381 2.74\%. Based on the study of the morphological characters we consider all 

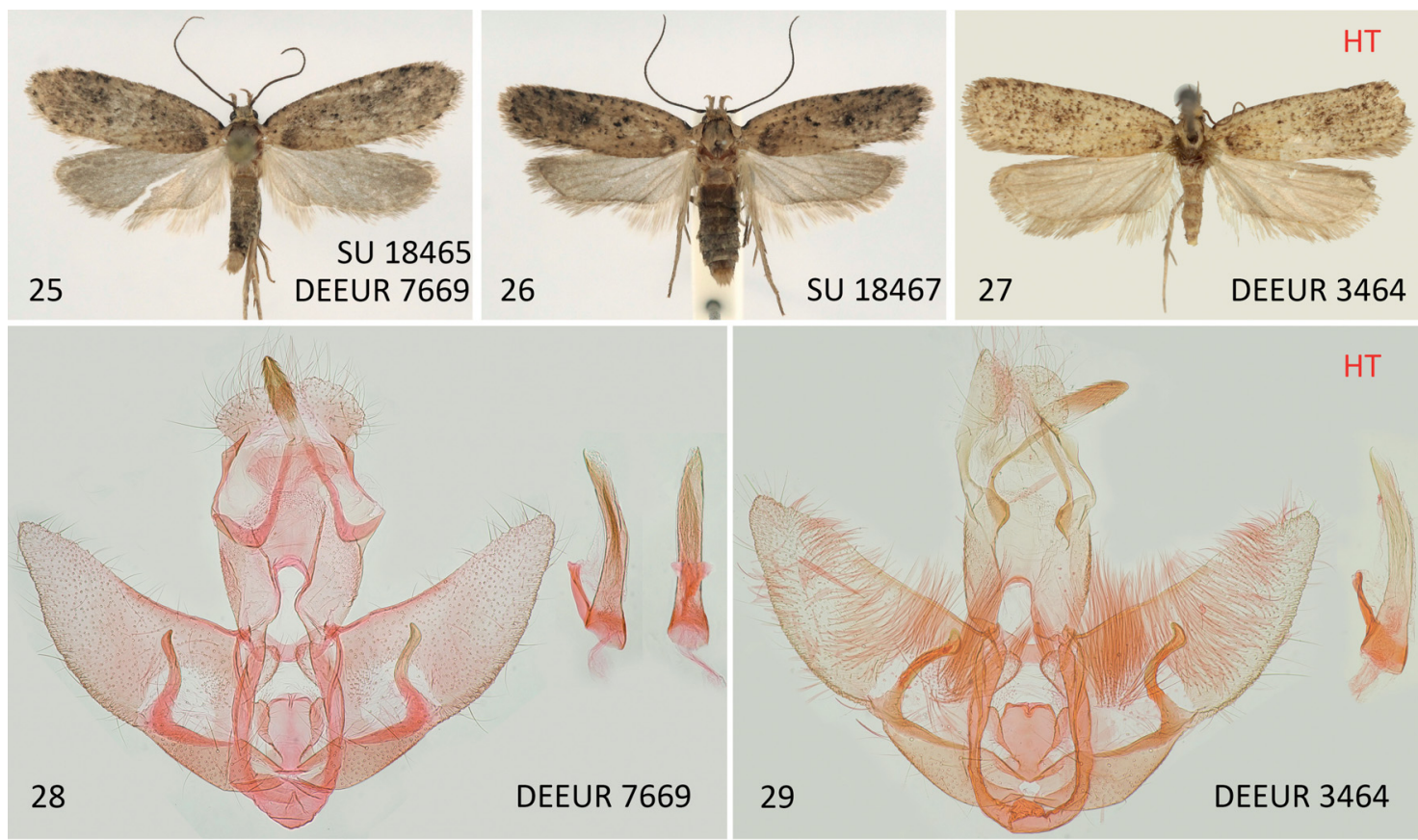

Figs 25-29. Agonopterix agyrella (Rebel, 1917). 25-27 - habitus; 25 - male, Russia, Altai Mts., Kurai, 30.vii.2017, J. Šumpich leg. (NMPC); 26 - female, Russia, Altai Mts., Dzhazator, confluence of Argut and Karagem rivers, 27.-28.vii.2017, J. Šumpich leg. (NMPC); 27 - holotype, Russia, Tannu Ola Mts, Schawyr, 2500 m, 1914, Bang Haas leg. (NHMW) (museum id. Hannemann gen. prep 357). 28 - male genitalia, data as fig. 25. 29 - male genitalia, data as fig. 27 (holotype).
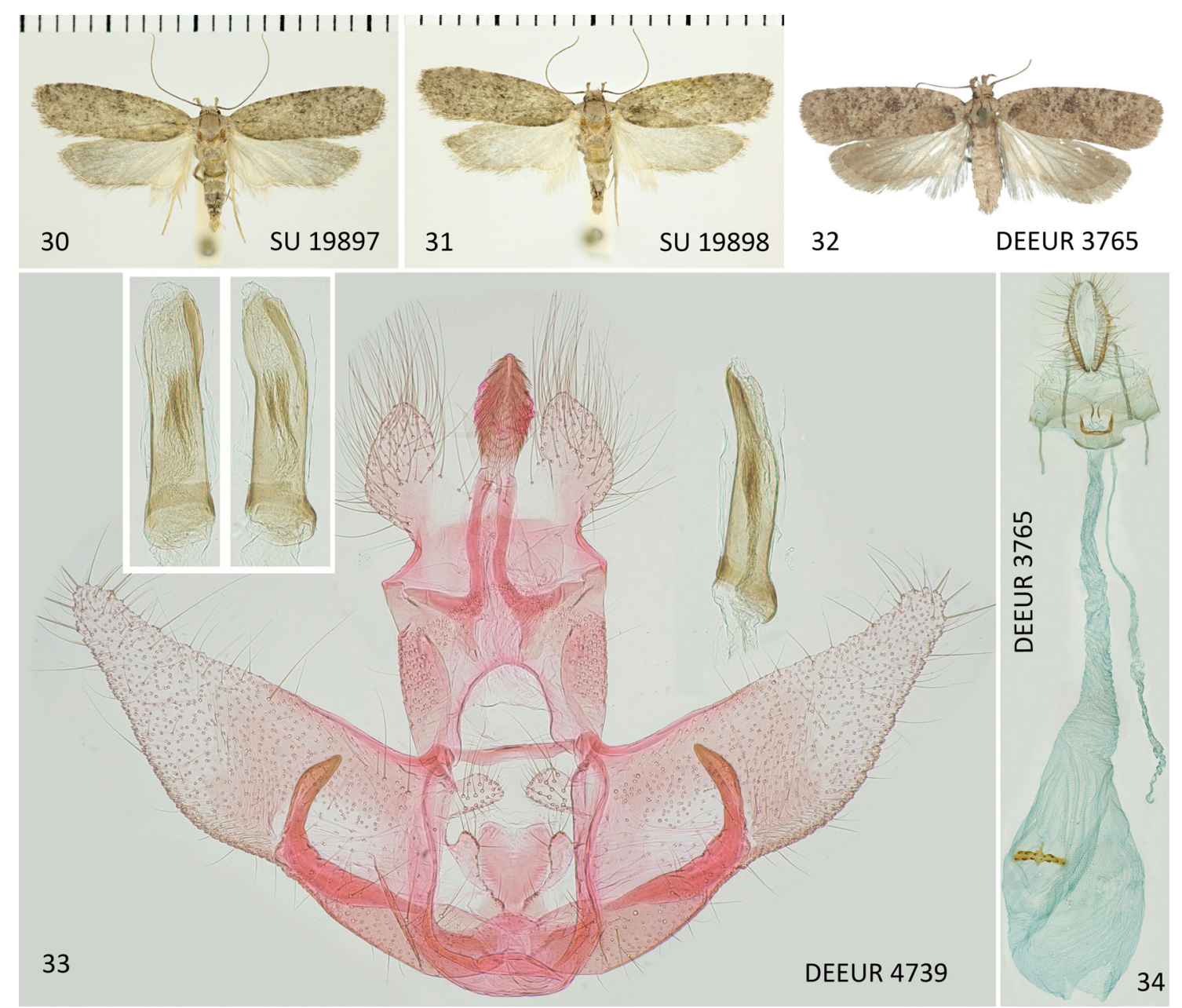

Figs 30-34. Agonopterix anticella (Erschoff, 1877). 30-32 - habitus: 30-31 - Russia, Altai Mts., Chulyshman, 4.-5.vii.2019, J. Šumpich leg. (NMPC); 32 - Russia, Amur region, Radde, without date, ex coll. C. S. Larsen (ZMUC). 33 - male genitalia, Russia, Primorsky krai, Gornotayozhnoe, 3.vi.2015, K. Nupponen \& R. Haverinen leg. (RCKN); 34 - female genitalia, data as fig. 32. 
specimens to belong to $A$. angelicella where the average intraspecific divergence of the barcode region is $0.69 \%$. Distribution. Palaearctic. In Russia widely distributed (Lvovsky 2006, 2008).

\section{Agonopterix anticella (Erschoff, 1877) (Figs 30-34)}

\section{= Agonopterix abjectella Christoph, 1882}

= Agonopterix japonicella Saito, 1980

Material examined. RUSSIA: Altai Republic: Aktash vill., $50^{\circ} 19^{\prime} 12^{\prime \prime} \mathrm{N}, 87^{\circ} 36^{\prime} 00^{\prime \prime} \mathrm{E}$, grassy steppe, rocks, $1400 \mathrm{~m}$, 21.vi.2015, 1 $\delta$ (Barcode NMPC-Lep-0153), J. Šumpich leg. (NMPC); Chulyshman valley, $45 \mathrm{~km} \mathrm{~N}$ of Ulagan vill., $51^{\circ} 01^{\prime} 03^{\prime \prime} \mathrm{N}, 88^{\circ} 00^{\prime} 39^{\prime \prime} \mathrm{E}$, grassy steppe, rocks, $600 \mathrm{~m}, 27 .-28 . v i .2015,3$ 우우 (Barcode TLMF Lep 23278), 26.-27. vi.2019, 14 ô $\widehat{~}$, 4.-5.vii.2019, 1 + , J. Šumpich leg. (NMPC).

Molecular data. BIN BOLD: ADC2511 $(\mathrm{n}=6$; 2 public, 2 from Altai). The average intraspecific divergence of the barcode region is $0.93 \%$ (maximum $2.46 \%$ ).

Distribution. Russia (eastern regions), China, Tibet (LvovSKY 2006). Presented records are the westernmost within its distribution area. The first record for the Altai Republic. Remarks. In these days it is better known under the name A. abjectella (Christoph, 1882). However, the type series of Christoph's species consists of two species: A. propinquella (Treitschke, 1835) and the species which was subsequently published under $A$. abjectella (including genitalia) by HANNEMANN (1953) and Lvovsky (2001). Hannemann had used for his studies a specimen collected by Hugo Theodor Christoph, but not from the type locality and clearly not part of the type series. The only museum, as far as we know, where true syntypes of $A$. abjectella (Christoph, 1882) are present, is the Natural History Museum in London, with two specimens. One had no abdomen, and the second, a male with abdomen, was used by B. V. Ridout in 1974 to fix a lectotype. But unfortunately, this specimen is $A$. propinquella. Although the designation of this lectotype was never published, it was a pending problem for this taxon. Later, A. Lvovsky found $A$. anticella to be an older name for $A$. abjectella and subsequently published it (LvovsKY 2018). The description of this taxon is based on a single male, and it is stored in the Zoological Institute of the Russian Academy of Sciences in St. Petersburg.

\section{Agonopterix arenella \\ (Denis \& Schiffermüller, 1775)}

Material examined. RUSSIA: Altai RePublic: Shebalino Distr., Cherga vill. (8 $\mathrm{km} \mathrm{W}), 51^{\circ} 34^{\prime} 04^{\prime \prime} \mathrm{N}, 85^{\circ} 28^{\prime} 33^{\prime \prime} \mathrm{E}$, rocky slopes, steppe, $580 \mathrm{~m}$, 8.-9.vii.2019, 2 ふふふ, J. Šumpich leg. (NMPC).

Molecular data. BIN BOLD: AAC6982 ( $\mathrm{n}=83 ; 78$ public, 0 from Altai). The average intraspecific divergence of the barcode region is $0.01 \%$ (maximum $0.33 \%$ ). Distribution. Palaearctic. In Russia widely distributed (Lvovsky 2006, 2008).

\section{Agonopterix bipunctosa (Curtis, 1850)} (Figs 35-38)

Material examined. RUSSIA: Altai Republic: Shebalino Distr., Cherga vill. (8 $\mathrm{km} \mathrm{W}), 51^{\circ} 34^{\prime} 04^{\prime \prime} \mathrm{N}, 85^{\circ} 28^{\prime} 33^{\prime \prime} \mathrm{E}$, rocky slopes, steppe, $580 \mathrm{~m}$, 16.vii.2017, 2 ðえ (Barcodes NMPC-LEP-0152, TLMF Lep 26026), J. Sumpich leg. (NMPC).

Molecular data. BIN BOLD: ABA0011 ( $\mathrm{n}=7 ; 6$ public, 2 from Altai). The average intraspecific divergence of the barcode region is $0.08 \%$ (maximum $0.32 \%$ ).

Distribution. Southern England, southern Sweden, France, Italy, Poland, Czech Republic, Hungary, Latvia, Russia (Lvovsky 2006). In Russia first reported by Lvovsky (2006), namely from south Ural and the Novosibirsk Region. New species for the Altai Republic.

\section{Agonopterix broennoeensis (Strand, 1920) (Figs 39-47)}

Material examined. RUSSIA: Altai Republic: Kosh-Agach Distr., Kurai env. (6.5 km SW), 50 $10^{\prime} 35^{\prime \prime} \mathrm{N}, 87^{\circ} 53^{\prime} 55^{\prime \prime} \mathrm{E}$, grassy steppe, 1550 m, 30.vii.2017, 7 đo (Barcode NMPC-LEP-0151), J. Šumpich leg. (NMPC); Kosh-Agach District, Beltir env. (16 km W), Chagan valley, 4957'06"N; 8753'39"E, 2150 m, 4.vii.2015, 1 (Barcode TLMF Lep 23317), M. Dvořák leg. (NMPC); Kosh-Agach Distr., Chagan-Uzun env., Krasnaya Gorka hill, $50^{\circ} 05^{\prime} 00^{\prime \prime} \mathrm{N}, 88^{\circ} 25^{\prime} 15^{\prime \prime} \mathrm{E}$, rocky steppe, $1870 \mathrm{~m}$, 29.vii.2017, 1 ふै, J. Šmpich leg. (NMPC).

Molecular data. BIN BOLD: AAF7537 ( $\mathrm{n}=11 ; 7$ public, 4 from Altai); BIN BOLD: ACF4026 $(\mathrm{n}=4$; 3 public, 1 from Altai). The average intraspecific divergence of the barcode region between both clusters is $1.28 \%$. According to the features of habitus as well as of genitalia characters all specimens belong to the same species with the average intraspecific divergence of the barcode region $0.70 \%$ (maximum $1.59 \%$ ). For comparison, the average intraspecific divergence of the barcode region of all Altaic specimens is $0.73 \%$ (maximum $1.10 \%$ ).

Distribution. Northern Europe, Russia (Altai Mts.) (Lvovsky 2006, HuEmer et al. 2017). In the Russian Altai it was recorded for the first time in the surroundings of Kosh-Agach village in the valley of Tabazhok river in 2016 (Huemer et al. 2017).

Remark. Two specimens (Figs 42, 43) from the surroundings of Beltir and Chagan-Uzun, both males, differ from the typically coloured specimens (Figs 39-41) in greater size and absence of reddish markings, but without distinct difference in the barcode. One specimen of the same appearance was collected also near Kosh-Agach (Tabazhok valley) in 2016 and subsequently published by HUEMER et al. (2017). Its dissection by the first author confirmed conspecifity with the two mentioned aberrant specimens (DEEUR 7742). At first it seemed possible that they might represent an undescribed species, so further differences were looked for in the genitalia. In fact, in the specimen from Beltir (Fig. 42) such a feature could be found in the shape of anellus lobes (Fig. 46c) (semi-elliptic, not semi-cordate as in typical A. broennoeensis, Fig. 45c). But in the second specimen from Chagan-Uzun (Fig. 43) the anellus lobes were typical for $A$. broennoeensis (Fig. 47c). This examination also brought to light a further feature, present in both the typical and untypical $A$. broennoeensis: cornuti are much stouter than in other species of the $A$. pallorella group. From this point it can only be concluded at the moment that the external differences are part of the intraspecific variability. 


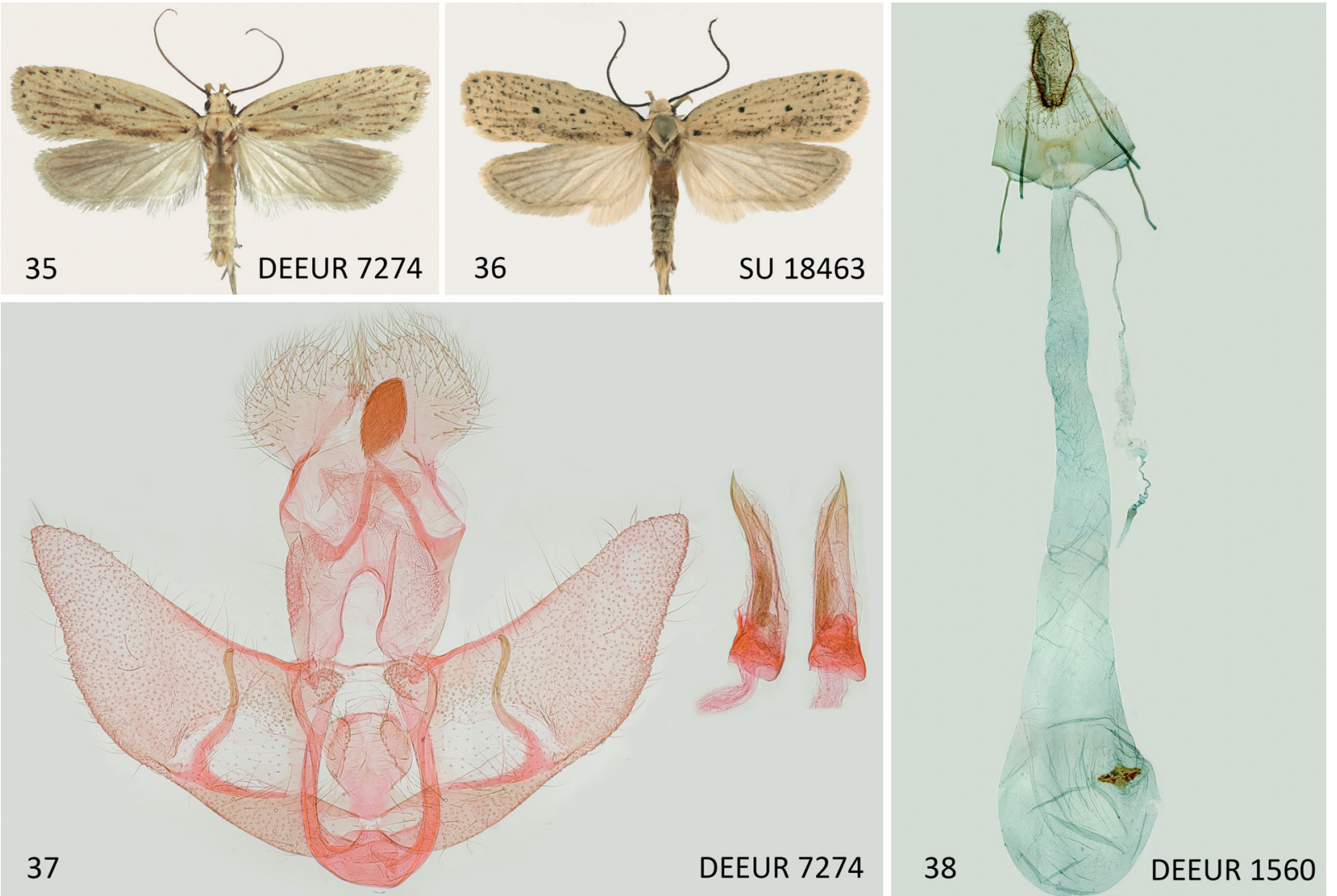

Figs 35-38. Agonopterix bipunctosa (Curtis, 1850). 35-36 - habitus, Russia, Altai Mts., Cherga, 16.vii.2017, J. Šumpich leg. (NMPC); 37 - male genitalia, data as fig. 35; 38 - female genitalia, Italy, Friuli, Carso Triestino., 24.viii.1999, L. Morin leg. (RCLM).

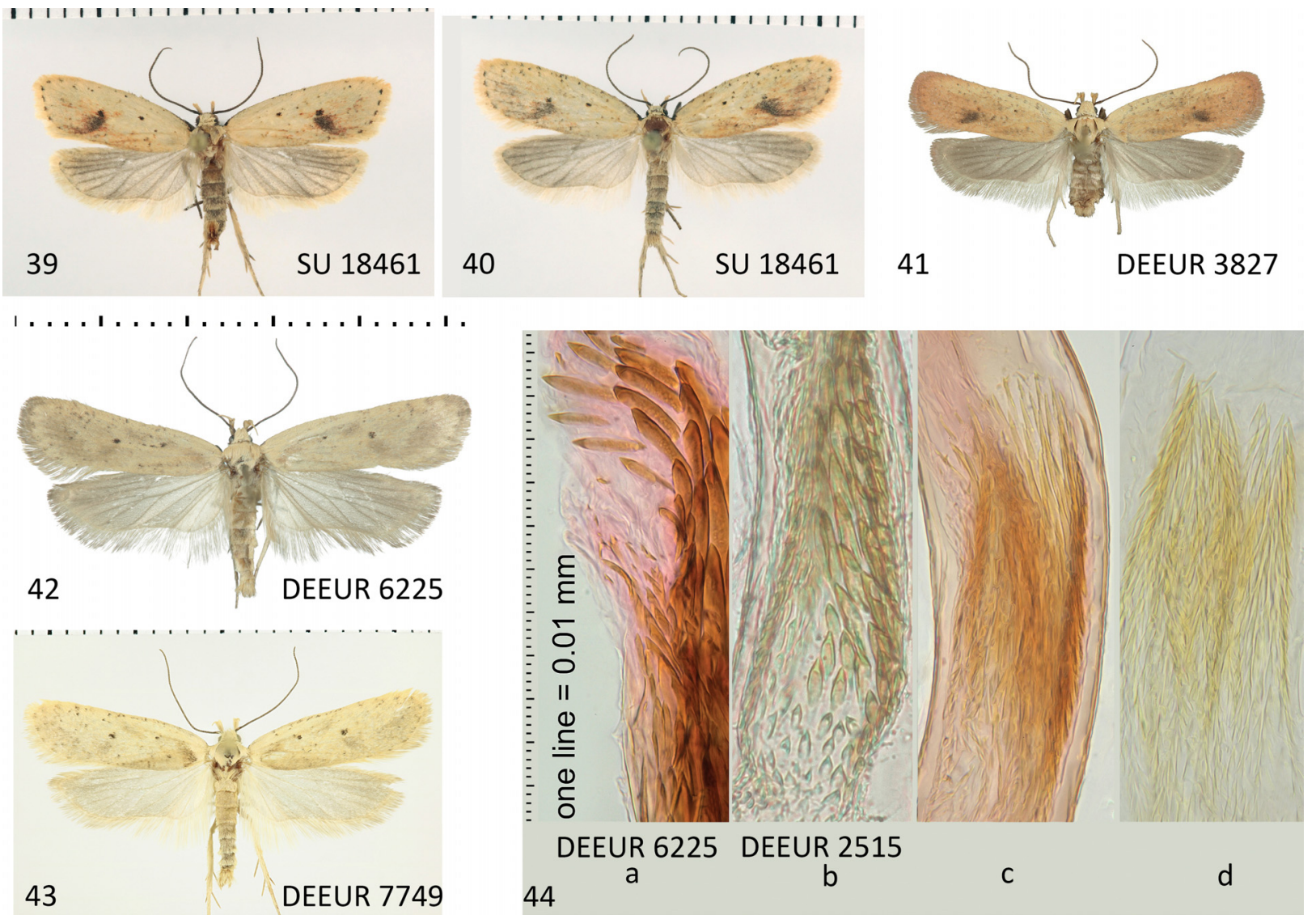

Figs 39-44. Agonopterix broennoeensis (Strand, 1920). 39-43 - habitus: 39-40 - Russia, Altai Mts., Kurai, 30.vii.2017, J. Šumpich leg. (NMPC); 41 - Norway, Kongsvold, 1000 m, O. Karsholt leg. (ZMUC); 42 - Russia, Altai Mts., Beltir, 4.vii.2015, M. Dvořák leg. (NMPC); 43 - Russia, Altai Mts., Krasnaya Gorka, 29.vii.2017, J. Šumpich leg. (NMPC). 44 - structure of cornuti in aedeagi of most similar taxa (a-b $-A$. broennoeensis, $\mathrm{c}-A$. kaekeritziana (Linnaeus, 1767), d-A. pallorella (Zeller, 1839)). 

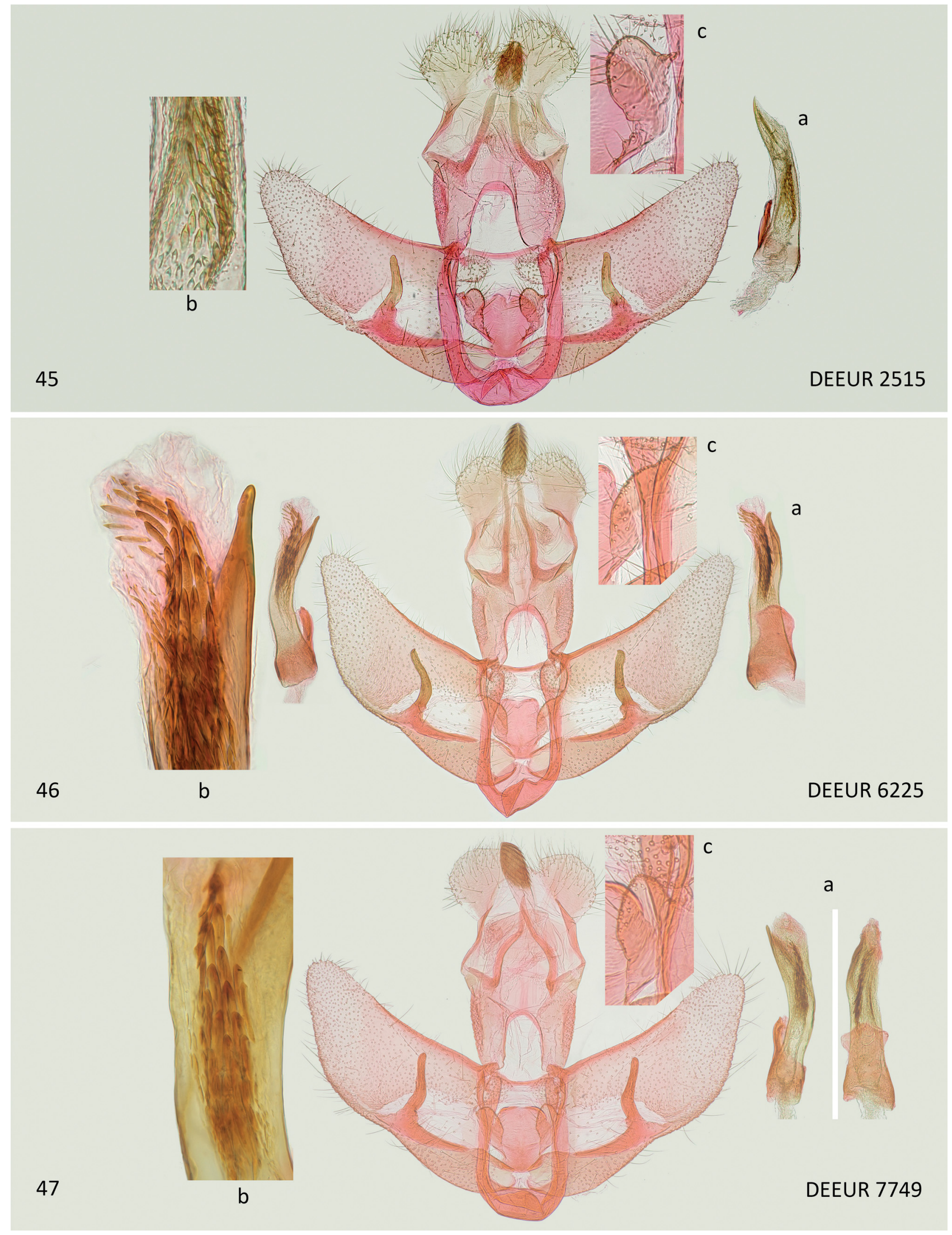

Figs 45-47. Male genitalia of Agonopterix broennoeensis (Strand, 1920). 45 - Russia, Kola peninsula, Apatity, 16.viii.2001, M. Kozlov leg. (ZMUC); 46 - data as fig. 42; 47 - data as fig. 43 (a - aedeagus; b - detail of cornuti in aedeagus; $\mathrm{c}$ - detail of anellus lobes). 


\section{Agonopterix kyzyltashensis sp. nov. \\ (Figs 48-55, 61-63)}

Type material. Holotype: $\lesssim$ (NMPC), RUSSiA: Altai Republic:

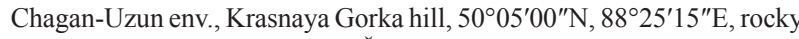
steppe, 1870 m, 29.vii.2017, J. Šumpich leg., gen. prep. DEEUR 7751. PARATYPES: RUSSIA: ChelyabinsKaya DISTRICT: Nikolaevka, $52.23^{\circ} \mathrm{N}$, 57.16 E, 3.vii.1997, 1 o (barcode TLMF Lep 19231), gen. prep. DEEUR 4587, L. P. Kaitila leg. (RCLK). Orenburg District: Malaja Hobda river, Shkunovka, $50.77^{\circ} \mathrm{N}, 55.37^{\circ} \mathrm{E}, 1 . i x .2000,1$ (B) (Barcode TLMF Lep 19250), 1 , gen. prep. DEEUR 4596 (ㅇ) and DEEUR 4597 (ठ̋), K. Nupponen leg. (RCKN); Schibendy valley, $20 \mathrm{~km}$ south Prokrovka, $50.67^{\circ} \mathrm{N}, 54.45^{\circ} \mathrm{E}, 2 . v i i .2003,1$ đ , photo DEEUR 6477, K. Nupponen leg. (RCKN); Verbljushka Mt. near Donskoe village, $51.38^{\circ} \mathrm{N}, 56.82^{\circ} \mathrm{E}$, 30.viii.2011, 1 ๙ (Barcode TLMF Lep 07116), gen. prep. DEEUR

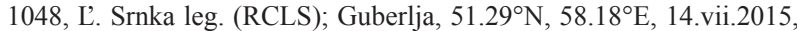
1 , photo DEEUR 4296, H. Roweck \& N. Savenkov leg. (ECKU).
KYRGYZSTAN: Tien-Shan mts., Baydulu range, Dolon pass, $2835 \mathrm{~m}$, $41.83^{\circ} \mathrm{N}, 75.79^{\circ} \mathrm{E}, 5 . v i i i .2010,1 \hat{\jmath}$ (barcode TLMF Lep 19339), gen. prep. DEEUR 4661, K. Nupponen \& R. Haverinen leg. (RCKN).

Description. Adult (Figs 48-53). Wingspan 20-24 mm. Head warm medium brown, face light greyish brown. Segment 2 of labial palp pale yellowish brown on inner side, speckled dark brownish grey ventrally and on outer side, segment 3 pale yellowish with fleshy tinge, completely without dark scales or a few at very tip. Antenna blackish. Thorax medium yellowish brown with diffuse darker longitudinal line in middle in anterior half, becoming generally darker towards anterior and lateral edges, with orange tinge at anterior edge, posterior crest absent, colour of tegulae similar to head and thorax. Forewing
48
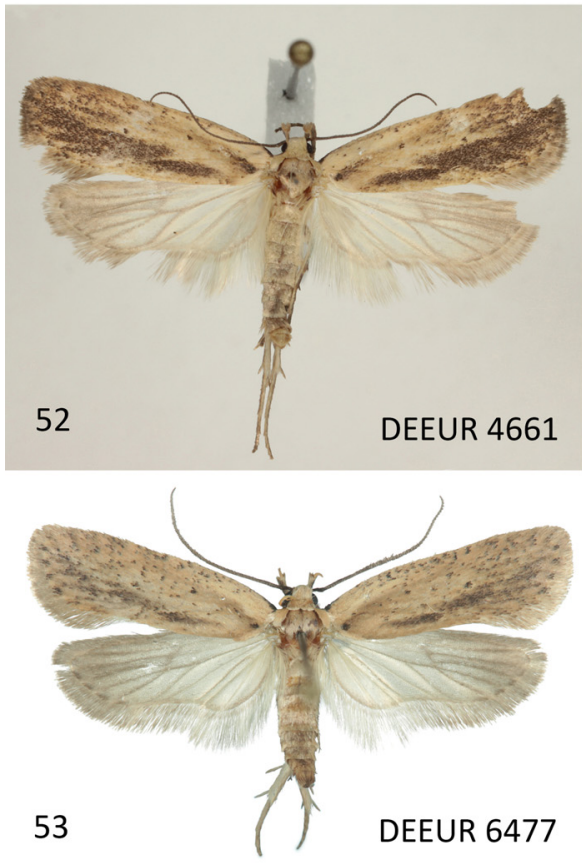
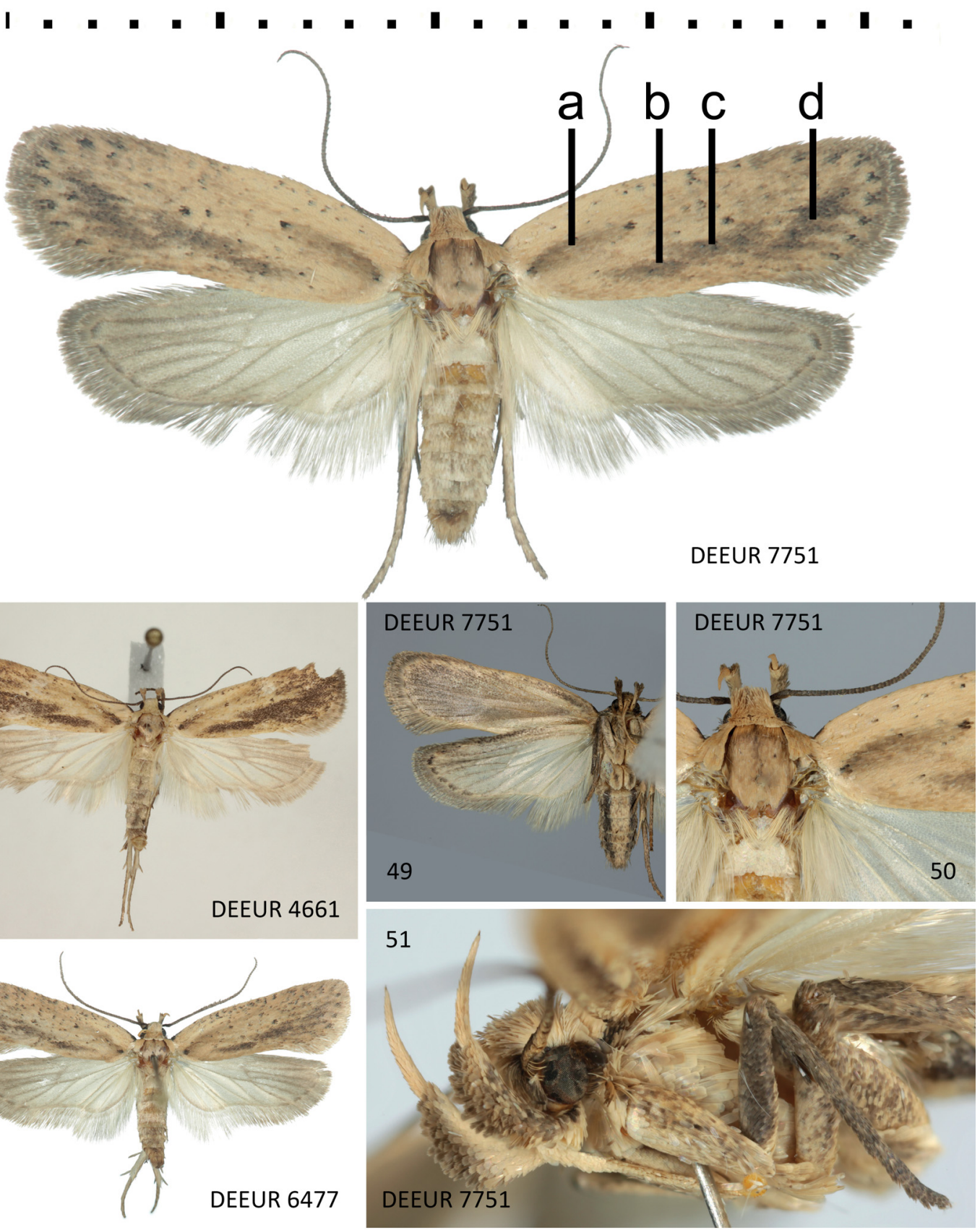

Figs 48-53. Agonopterix kyzyltashensis sp. nov. 48-51 - holotype, Russia, Altai Mts., details in text: 48 - habitus (dorsal view); 49 - habitus (ventral view); 50 - details of thorax and base of wings; 51 - details of labial palpi and legs. 52-53 - paratypes, data in the text: 52 - Kyrgyzstan; 53 - Russia, S Ural, Schibendy. 
medium warm brown, with scattering of dark fuscous scales in low numbers, becoming more numerous distally. Basal field similar to ground colour; costa with blackish dot at base; costal spots indistinct or absent; terminal spots blackish; blackish dot in cell at $1 / 3$, another at end of cell at about $3 / 5$, both small with diameter of about 0.20-0.25 mm, without white elements; dark fuscous to blackish stripe from close to base of dorsum to first cell spot gradually fading along its length, forming distinct stripe parallel to costa with width of about $1 / 5$ of forewing width (Fig. 48a); another longitudinal stripe is developed in dorsal third, originating at $1 / 4$ with width of about $1 / 5$ of forewing width, it extends to $2 / 5$, here it becomes a little weaker or even interrupted (Fig. 48b), then it extends by becoming slightly broader to $3 / 5-2 / 3$ where it again becomes weaker or even interrupted (Fig. $48 \mathrm{c}$ ), and it continues by becoming distinctly broader and reaches half of forewing width before it ends subterminally, only along veins dark elements nearly reach termen (Fig. 48d); fringe dark greyish brown, basal row of fringe scales with paler tips, forming distinct fringe line; underside brownish grey, with concentration of darker brown scales near basal half of costa, termen with small blackish interneural dots. Hindwing greyish brown, little darker towards termen, veins contrasting by being darker; fringe similar to ground colour, rather dark grey in distal
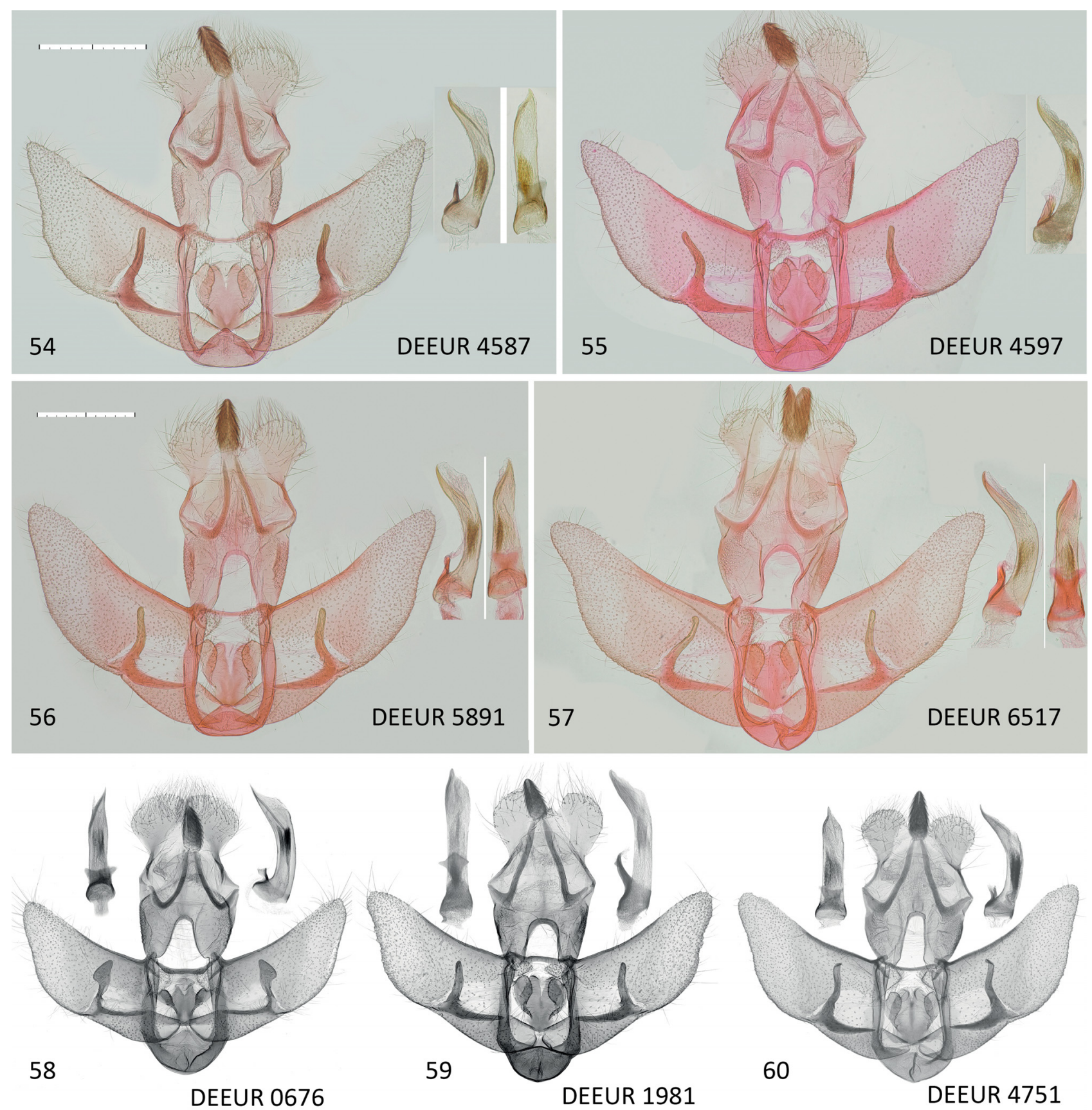

Figs 54-60. Male genitalia. 54-55 - Agonopterix kyzyltashensis sp. nov., paratypes, Russia, S Ural, details in text; 56-57 - A. pullella Hannemann, 1971: 56 - Mongolia, Cojbalsan Aimak, 15 km north of Somon Galuut, 17.viii.1965, Z. Kaszab leg. (HNHM); 57 - Russia, Buryatia, 35 km south W of Ulan Ude, 17.vii.1996, Kullberg \& Jalava leg. (ZMUH); 58 - A. pallorella (Zeller, 1839), Lower Austria, Perchtodsdorf, 3.vi.2010, P. Buchner leg. (RCPB); 59 - A. straminella (Staudinger, 1870), Tunisia, Jebel Chambi, 23.x.2009, L. Lehmann leg. (RCGD); 60 - A. kaekeritziana (Linnaeus, 1767), Lower Austria, Fischawiesen, 22.vi.2011, W. Stark leg. (RCWS). Scale bar for figs 54-57 = $1 \mathrm{~mm}$. 
half of hindwing, with one distinct fringe line. Underside medium greyish, darker along costa, with distinct blackish interneural dots. Abdomen light yellowish grey on upperside, light brown with 2 distinct dark lateral lines on underside. Legs covered with mix of pale yellowish and dark grey scales, but tibia and tarsus of fore- and midlegs predominantly dark grey.

Variation. The dark fuscous to blackish fascia from basal field to basal dot and the longitudinal stripe in dorsal third show some variation in width and intensity; also the number of fuscous scales scattered through the pale ground colour varies (Fig. 52).
Male genitalia (Figs 54-55). Socii medium-sized, broadly elliptic, $0.5-0.6 \mathrm{~mm}$ wide and $0.6 \mathrm{~mm}$ long, uncus triangular, indistinct, gnathos narrowly elliptic, medium-sized, $0.2 \mathrm{~mm}$ wide and $0.5 \mathrm{~mm}$ long, overtopping socii in standard preparation by about third of its length. Transtilla narrow, not widened medially with width of about $0.05-0.06 \mathrm{~mm}$, transtilla lobes semi-elliptic, $0.3 \mathrm{~mm}$ wide and $0.2-0.3 \mathrm{~mm}$ long, gap between them $0.15-0.20$ $\mathrm{mm}$. Anellus medium-sized, round, length/width $0.6 / 0.6$ $\mathrm{mm}$, gap to transtilla $0.2 \mathrm{~mm}$, caudal margin with distinct elliptic bulge towards transtilla on either side and $0.20-0.25$ mm deep V-shaped central incision in between, filled with

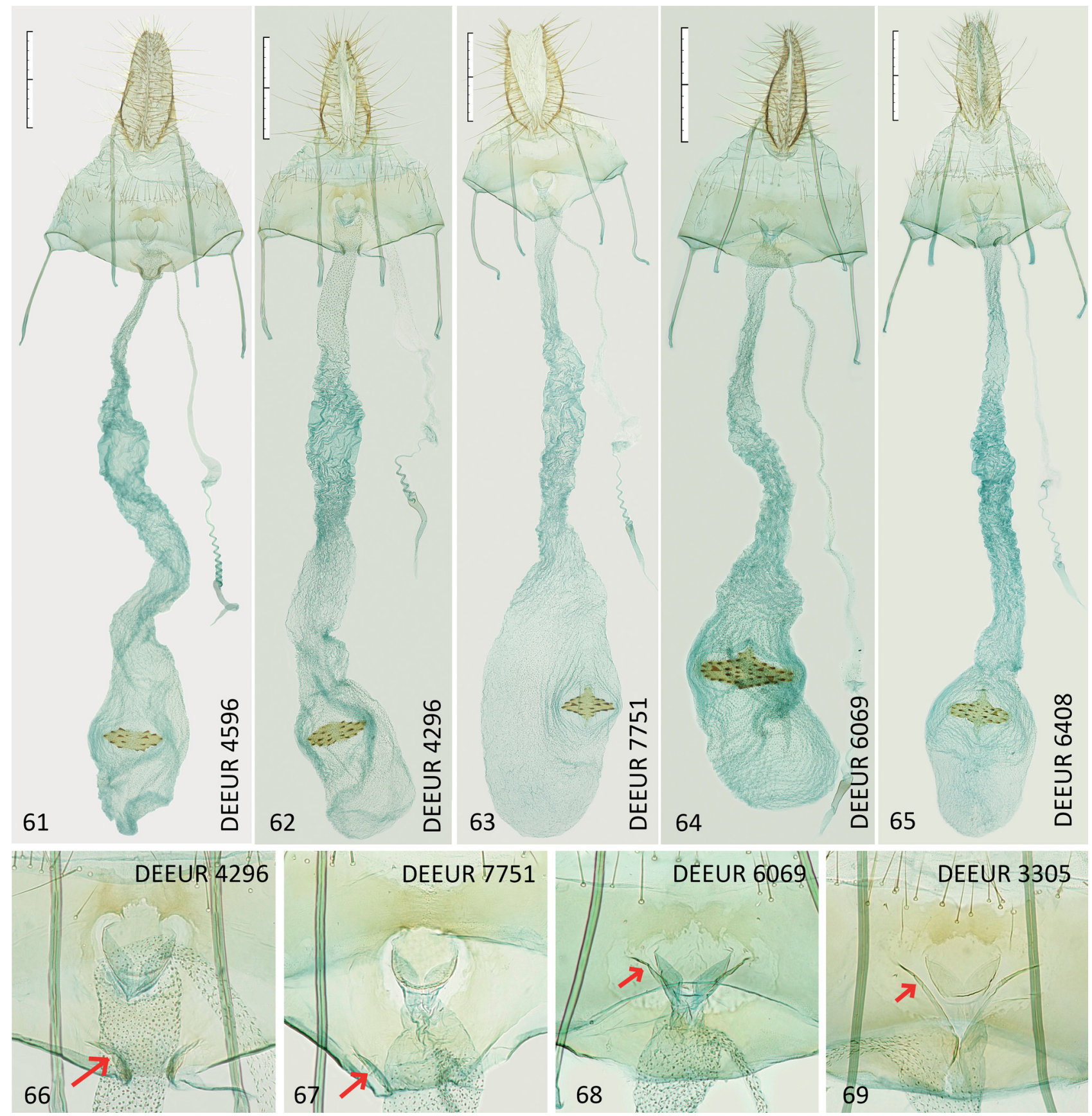

Figs 61-69. Female genitalia. 61-65 - general view: 61-63 - Agonopterix kyzyltashensis sp. nov., paratypes, Russia, S Ural, details in the text: 61-62 Russia, S Ural; 63 - Russia, Altai; 64 - A. pallorella (Zeller, 1839), Turkey, Tuz Gölü, 20.vii.1970, Friedel leg. (SMNK); 65 -A. kaekeritziana (Linnaeus, 1767), Italy, Toscana, Badia della Valle, 15.vi.1982, A. Usvelli leg. (MFSN). 66-69 - details of antrum: 66-67 - A. kyzyltashensis sp. nov., paratypes, details in the text: 66 - Russia, S Ural; 67 - Russia, Altai; 68-69 - A. pallorella: 68 - Turkey, Tuz Gölü, 20.vii.1970, Friedel leg. (SMNK); 69 - Turkey, Sivas, Gök Pınar, 1.viii.1997, K. Larsen leg. (RCKL). Scale bar for figs 61-65=1 mm. 

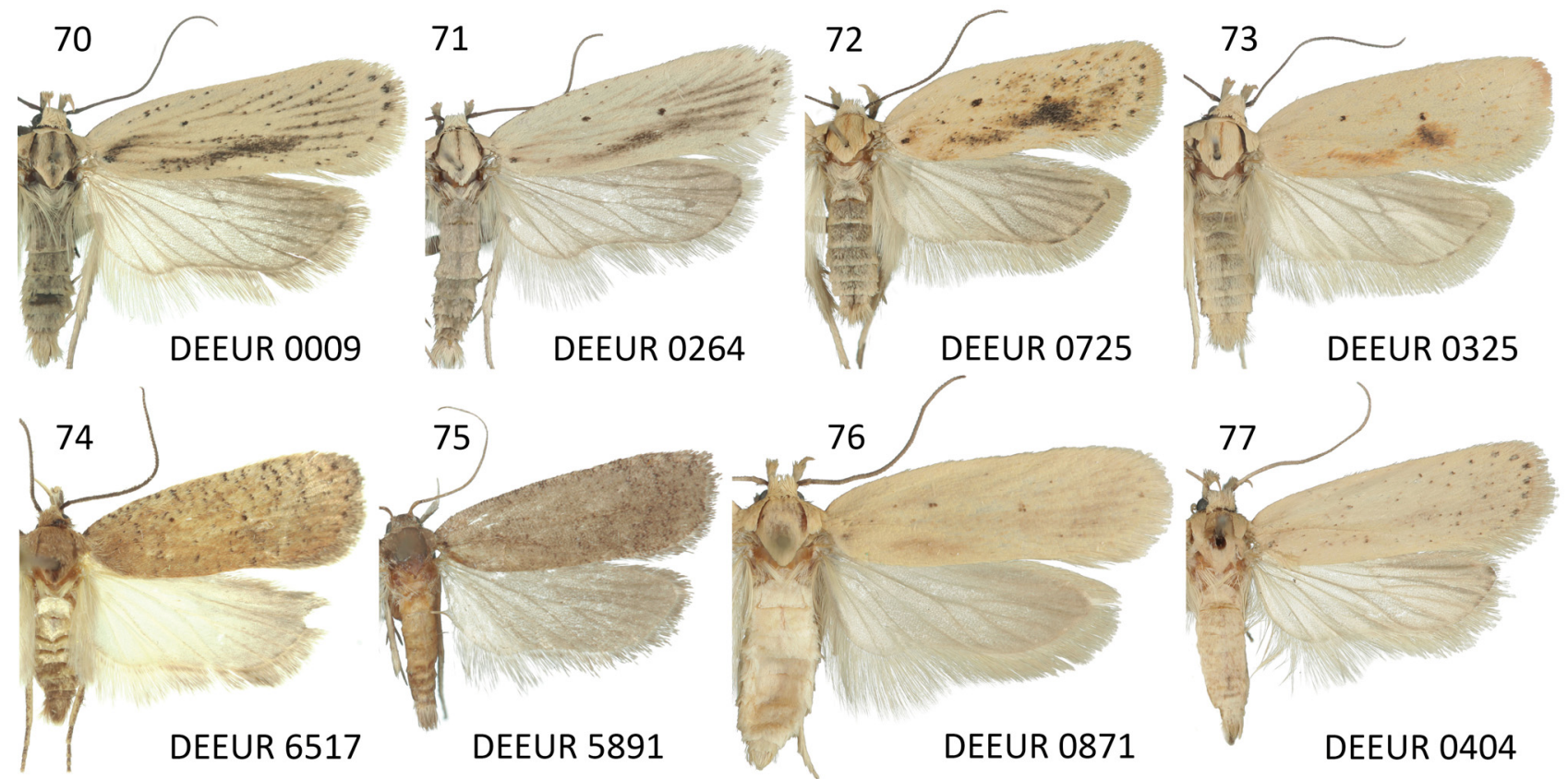

Figs 70-77. Comparison of related Agonopterix taxa based on habitus features. 70-71 - Agonopterix pallorella (Zeller, 1839): 70 - Lower Austria, Perchtodsdorf, 3.vi.2010, P. Buchner leg. (RCPB); 71 - Lower Austria, Waschberg, 8.iv.2010, W. Stark leg. (RCWS); 72-73 - A. kaekeritziana (Linnaeus, 1767): 72 - Lower Austria, Fischawiesen, 22.vi.2011, W. Stark leg. (RCWS); 73 - Lower Austria, Perchtodsdorf, 25.vi.2010, P. Buchner leg. (RCPB); 74-75 - A. pullella Hannemann, 1971: 74 - Russia, Buryatia, 35 km south W of Ulan Ude, 17.vii.1996, Kullberg \& Jalava leg. (ZMUH); 75 - Mongolia, Cojbalsan Aimak, 15 km north of Somon Galuut, 17.viii.1965, Z. Kaszab leg. (HNHM); 76-77 - A. straminella (Staudinger, 1870 ): 76 - Syria, 60 km NE of Ladikije, 7.vi.1961, Kasy \& Vartian leg. (ZSM); 77 - Morocco, Ifrane, 22.x.1973, Friedel leg. (TLMF).

thin membrane, anellus lobes medium-sized, elliptic, with distinct bulge towards transtilla which gives them semicordate appearance, length $0.4-0.5 \mathrm{~mm}$, width $0.20-0.25$ $\mathrm{mm}$. Valva about $2.3 \mathrm{~mm}$ long, $1.0-1.1 \mathrm{~mm}$ broad at base, tapering to about $0.9 \mathrm{~mm}$ at origin of cuiller, then widening a little before evenly tapering to its tip. Cuiller of medium width with about $0.1 \mathrm{~mm}$ diameter in its middle, slightly tapering in distal half, slightly to moderately outcurved in its middle $\left(15-40^{\circ}\right)$, distal half straight, ending about 0.2 $\mathrm{mm}$ before costa of valva. Aedeagus $1.3-1.4 \mathrm{~mm}$ long, in lateral view bent $\left(50-55^{\circ}\right)$, diameter $0.2 \mathrm{~mm}$ except for somewhat swollen basal part, where it reaches $0.3 \mathrm{~mm}$, sclerotised basal parts with total length of about $0.5 \mathrm{~mm}$, free section about $0.2 \mathrm{~mm}$, in ventral view about as wide as in lateral view, tapering to sharp tip in its terminal 1/4, free part of basal sclerotisation $0.2 \mathrm{~mm}$ wide at its base, expanding to $0.3 \mathrm{~mm}$ and terminating with shallow $\mathrm{V}$-shaped excavation. Vesica (uneverted) with numerous tiny cornuti in group of about $1 / 3$ of aedeagus length.

Female genitalia (Figs 61-63). Papilla analis about 1.1-1.2 mm long and $0.6 \mathrm{~mm}$ broad in lateral view, posterior apophysis $1.6-1.7 \mathrm{~mm}$. Sternite VIII $0.7 \mathrm{~mm}$ long, maximum width $1.8-2.0 \mathrm{~mm}$ in standard preparation, anterior apophysis $1.0-1.1 \mathrm{~mm}$. Proximal edge of sternite VIII evenly concave, with $0.20-0.25 \mathrm{~mm}$ long fold on either side, may be rather thick in its middle with width up to $0.05 \mathrm{~mm}$, but appearance also depends on preparation details, distance between inner ends of folds $0.15-0.20 \mathrm{~mm}$. Ostium slightly distal to middle of sternite VIII, round with diameter of about $0.3 \mathrm{~mm}$, area of stronger sclerotisation between ostium and distal edge of sternite VIII. Ductus bursae starting with width of about $0.1-0.3 \mathrm{~mm}$ without distinct structures apart from numerous tiny dots, after about $1.0 \mathrm{~mm}$ the tiny dots disappear and ductus widens up to $0.5 \mathrm{~mm}$, showing rather rough irregular folds, after another about $1.0 \mathrm{~mm}$ it slightly constricts and irregular folds get tighter, and again after about $1.0-1.5 \mathrm{~mm}$ it widens to corpus bursa with length/width ratio of about $2 / 1$ and length up to $3 \mathrm{~mm}$, signum elliptic with longitudinal/transverse expansion of $0.2 / 0.6 \mathrm{~mm}$ with about 15-20 triangular teeth, in longitudinal axis narrow process on either side can be developed or not. Origin of ductus spermathecae very close to ostium and ending with about 6-8 turns. Although width and details of structure of ductus and corpus bursae reflect life history, especially whether the specimen has mated or not, the division of ductus bursae into 3 different sections is distinct, but it is not an exclusive feature of this species as it is found in most species of the Agonopterix pallorella group, further details see in Differential diagnosis.

Differential diagnosis. Externally, the new species is very distinct due to the dark longitudinal stripe in rear half of forewing, which tends to be divided in 3 sections and with width increasing from base to termen (Figs 48, 52-53). Only some forms of $A$. pallorella (Zeller, 1839) may be similar with a risk of confusion if the specimens are not in good condition, but here the dark longitudinal stripe is restricted to basal 2/3 of forewing (Figs 70-71) and genitalia of both sexes are clearly different. In $A$. kaekeritziana (Linnaeus, 1767) the dark elements are mixed with rusty brown and more or less restricted to a spot distal to the dot at the end of cell (Fig. 73), rarely the dark elements are extended, but always with a clear 
concentration distal to the cell dot (Fig. 72); genitalia are similar in males and barely separable in females. In A. pullella Hannemann, 1971 (Figs 74-75), forewings show warm medium brown to dark brown ground colour with groups of darker scales forming irregular narrow transverse bands but longitudinal dark stripes are absent, so external appearance is very different from $A$. kyzyltashensis but genitalia are not separable. Agonopterix straminella (Staudinger, 1870) is a further species with nearly inseparable genitalia but its forewing appearance is clearly different with yellowish ground colour without longitudinal dark elements (Figs 76-77).

Male genitalia of the new species are inseparable from those of $A$. pullella (Figs 56-57). In cases of doubt diagnosis must be based on external appearance. Agonopterix straminella (Fig. 59) also shows very similar male genitalia, in the specimens that could be compared only the shape of the basal process of aedeagus is clearly different in being much longer and its ending not convex in A. straminella, but it is not known whether this feature is reliable in all cases. Agonopterix kaekeritziana (Fig. 60) usually differs in cuiller being slightly S-curved, although the shape of cuiller is variable within this species and specimens where it is only outcurved can be found, but they are rare and in combination with external appearance a safe determination should be possible. Agonopterix pallorella, where some forms can be rather similar to A. kyzyltashensis externally, has cuiller with triangular swelling in the apical half (Fig. 58), which separates it clearly from all the other species of the A. pallorella group.
Female genitalia of $A$. pallorella, which is externally the most similar species within this group, are safely separable by the absence of folds on the proximal edge of sternite VIII and the presence of an oblique fold on either side of ostium (Figs 64, 68-69 [red arrows]), while in A. kyzyltashensis the folds lateral to the ostium are absent, but a pair of folds is developed near the middle of the proximal edge of sternite VIII (Figs 61-63, 66-67 [red arrows]). If these structures are used for determination it should be kept in mind that they are not distinct sclerotisations, and also the term "fold" is not strictly correct, it would be better to call them gullies, ditches or pits. When compressed, these structures may become folds and therefore more distinct than before, but sometimes they become smooth and then they may be nearly invisible. Despite this disadvantage, these structures are very helpful features to distinguish Agonopterix species by female genitalia, because sometimes this area is the only one with clear differences between the species.

Molecular data. BIN BOLD: ACF7591 ( $\mathrm{n}=3$, 1 public, 0 from Altai). The average intraspecific divergence of the barcode region is $0.51 \%$ (maximum $0.76 \%$ ).

Etymology. The species name is derived from the Altaic name of the collecting place (Kyzyltash = Krasnaya Gorka in Russian = Red Mountain in English); adjective.

Biology. Food plant unknown so far, but with all species of the A. pallorella group feeding on Asteraceae, it is likely this is also the case with A. kyzyltashensis.

Distribution. Russia (southern Ural: Chelyabinskaya and Orenburg districts; the Altai Republic), Kyrgyzstan (Tien-Shan Mts.).
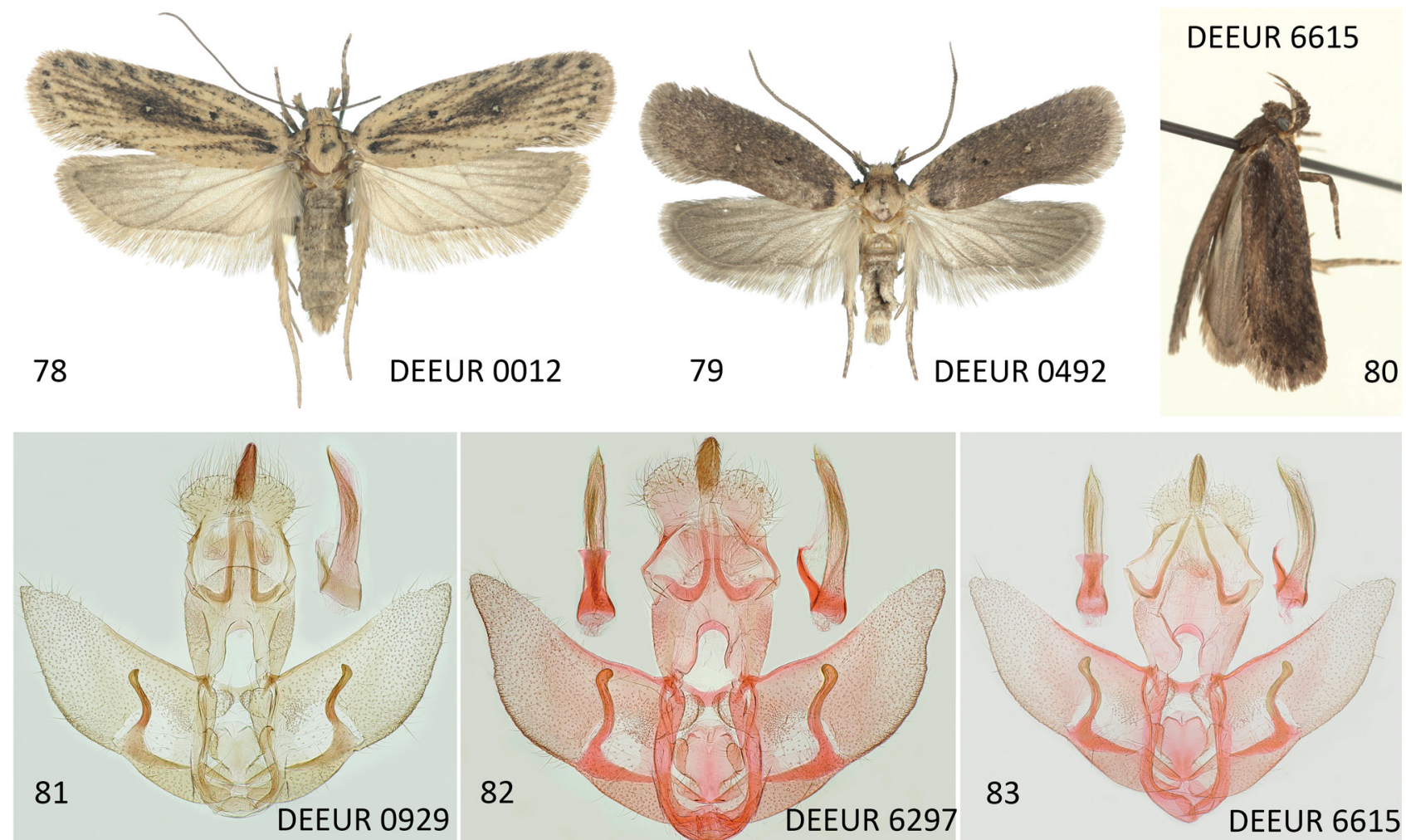

Figs 78-83. Agonopterix putridella ([Denis \& Schiffermüller], 1775). 78-80 - habitus: 78 - Austria, Eichkogel, 16.viii.2009, P. Buchner leg. (RCPB); 79 - France, Var, Le Muy, 15.v.2011, e. 1. Peucedanum officinale, P. Sonderegger leg. (NMBE); 80 - Russia, Altai Mts., Krasnostchekovo, Tigirek Vill, 9.vii.2014, S. Sinev leg. (ZIN). 81-83 - male genitalia: 81 - Austria, Eichkogel, 1.v.-15.vi.2012, e. 1. Peucedanum alsaticum, P. Buchner leg. (RCPB); 82 - France, Golfe Juan, without date, Constant leg. (MGAB); 83 - data as fig. 80. 


\section{Agonopterix putridella \\ (Denis \& Schiffermüller, 1775) \\ (Figs 78-83)}

Material examined. RUSSIA: Altai Region: Krasnostchekovo, Tigirek

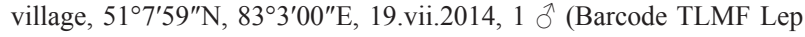
23527, gen. prep. DEEUR 6615), 1 q (Barcode TLMF Lep 26030), S. Sinev leg. (ZIN).

Molecular data. ( $\mathrm{n}=14 ; 2$ from Altai). The average intraspecific divergence of the barcode region is $1.46 \%$ (maximum 2.96\%). However, in this species a closer look at the puzzling barcode situation is needed. It is split into 2 clusters. The first has BIN BOLD ABA0436 ( $\mathrm{n}=10$, 2 from Altai); the average divergence within this cluster is $0.64 \%$ (maximum $1.62 \%$ ). Here only $A$. putridella is found, with distribution range from France to Greece, Turkey and Russia (east to the Altai). The second has BIN BOLD AAF7185 ( $\mathrm{n}=15,0$ from Altai), it includes A. putridella from Austria and Scandinavia, but also $A$. agyrella, A. septicella, A. archangelicella (Caradja, 1920), and A. buryatica Lvovsky \& Knyazev, 2016. Although it consists of 5 species, distances are small throughout; the average divergence within this cluster is $0.61 \%$ (maximum $1.23 \%$ ). Maybe this is caused by introgression; however, the barcodes in this species group are of limited use.

Distribution. Europe, Caucasus (Armenia), Afghanistan (Lvovsky 2006). From Russia it is mentioned by CARADJA (1920: 128), namely from „Symonowsk“ (= Сеймоновск, a city district of Miass, Chelyabinsk Region) but this record was accepted by LvOvSKY (2006: 75) with doubts. Confirmed occurrence in Russia.

Remarks. Agonopterix putridella was described from Austria near Vienna, where forms with distinct black vein-associated streaks on forewings are typical (Fig. 78). But there are also forms with forewings more or less completely blackish (Fig. 79). Neither of these forms are known in any closely related species and therefore they are safely determinable. Pale forms with poor markings also occur, and in areas where A. agyrella is found, determination based on external features can be impossible. Male genitalia of A. putridella and A. agyrella are generally similar, cuiller tends to be longer and in some specimens nearly reaching costa of valva in A. putridella, but forms with cuiller not longer than 3/4 of valva width can be found in both species. Barcode sharing of some populations of $A$. putridella with A. agyrella further complicates the distinction.

The specimens from the Altai are not influenced by this problem. Both belong to the blackish form (Fig. 80); the male has a cuiller with a length clearly indicative of $A$. putridella, and their barcodes are found in the first cluster where no further species are located.

\section{Agonopterix rimulella (Caradja, 1920) stat. restit. (Figs 84-85, 88-89, 92-94) \\ = Agonopterix liturosa rimulella Caradja, 1920 sensu LvovsKy \& STA- NESCU (2019)}

Material examined. RUSSIA: Altai Republic: Chemal vill. (2 km $\mathrm{SW}$ ), $51.383^{\circ} \mathrm{N}, 85.983^{\circ} \mathrm{E}, 450 \mathrm{~m}, 8$.viii.2016, 1 ơ (Barcode KLM Lep 06358), Ch. Wieser leg. (LMK).

Molecular data. BIN BOLD: ADE5615 $(n=3,0$ public, 1 from Altai). The average intraspecific divergence of the barcode region is $0.43 \%$ (maximum $0.48 \%$ ).

Distribution. Russia (the Far East), northern China (LvovSKY 2006). The first record for the Altai Republic.

Remarks. Lvovsky \& StAnescu (2019) classify this taxon as a subspecies of $A$. liturosa (Haworth, 1811) and give the following reasons: " $A$. liturosa rimulella is very similar in external appearance with the nominative subspecies, from which it differs only through its dark brown head and thorax and the absence of short black stroke in the middle of the cell. The specimens from nominotypical subspecies have usually light head and thorax and the short black stroke in the middle of the cell. The genitalia structures are identical (Fig. 14), as well as the food plants of larvae (Hypericum L.)." Molecular data were not included in this decision. However, looking at the barcode situation in the Agonopterix hypericella species group, no indication for the placement of $A$. rimulella as a subspecies of $A$. liturosa can be found as presented below.

Molecular data, food plants and genitalia indicate that this is a natural group, well separated from the rest of

Table 1. Comparison of species most similar to A. rimulella (Caradja, 1920) based on genitalia.

\begin{tabular}{|c|c|c|c|}
\hline Character & A. liturosa & A. rimulella & A. conterminella \\
\hline \multicolumn{4}{|l|}{ Male } \\
\hline $\begin{array}{l}\text { gnathos (especially uncompressed, } \\
\text { in lateral view) }\end{array}$ & $\begin{array}{l}\text { smallest gnathos of the } 3 \text { compared } \\
\text { species }\end{array}$ & $\begin{array}{l}\text { largest gnathos of the } 3 \text { compared } \\
\text { species }\end{array}$ & $\begin{array}{l}\text { gnathos of medium size, rather } \\
\text { short, comparatively broad }\end{array}$ \\
\hline upper margin of anellus & $\begin{array}{l}\text { bulges at either side of central inci- } \\
\text { sion nearly triangular, inner edges } \\
\text { nearly straight }\end{array}$ & $\begin{array}{l}\text { bulges at either side of central } \\
\text { incision semicircular, inner edges } \\
\text { evenly rounded }\end{array}$ & $\begin{array}{l}\text { bulges at either side of central } \\
\text { incision semicircular, inner edges } \\
\text { evenly rounded }\end{array}$ \\
\hline base of anellus & $\begin{array}{l}\text { constricted to a base broader than } \\
\text { half of maximal width of anellus }\end{array}$ & $\begin{array}{l}\text { constricted to a base narrower than } \\
\text { half of maximal width of anellus }\end{array}$ & $\begin{array}{l}\text { constricted to a base broader than } \\
\text { half of maximal width of anellus }\end{array}$ \\
\hline cuiller & $\begin{array}{l}\text { rather stout, broadest in distal } \\
\text { half, of moderate length (ending } \\
25-32 \% \text { of valva width before } \\
\text { costa) }\end{array}$ & $\begin{array}{l}\text { rather slim, nearly of the same } \\
\text { width throughout its whole length } \\
\text { or slightly broader in its middle, } \\
\text { long (ending } 16-22 \% \text { of valva } \\
\text { width before costa) }\end{array}$ & $\begin{array}{l}\text { moderately stout in basal } 2 / 3-3 / 4 \text {, } \\
\text { slightly to moderately swollen at } \\
\text { its tip }\end{array}$ \\
\hline \multicolumn{4}{|l|}{ Female } \\
\hline position of ostium in sternite VIII & distinctly proximal to centre & in or slightly proximal to centre & in or slightly proximal to centre \\
\hline $\begin{array}{l}\text { outline of papilla analis in lateral } \\
\text { view (uncompressed) }\end{array}$ & $\begin{array}{l}\text { parallel-sided in basal half, slightly } \\
\text { tapering in distal half }\end{array}$ & $\begin{array}{l}\text { parallel-sided in basal } 2 / 3 \text {, slightly } \\
\text { tapering in distal } 1 / 3\end{array}$ & $\begin{array}{l}\text { parallel-sided in basal } 3 / 4 \text {, slightly } \\
\text { tapering in distal } 1 / 4\end{array}$ \\
\hline
\end{tabular}



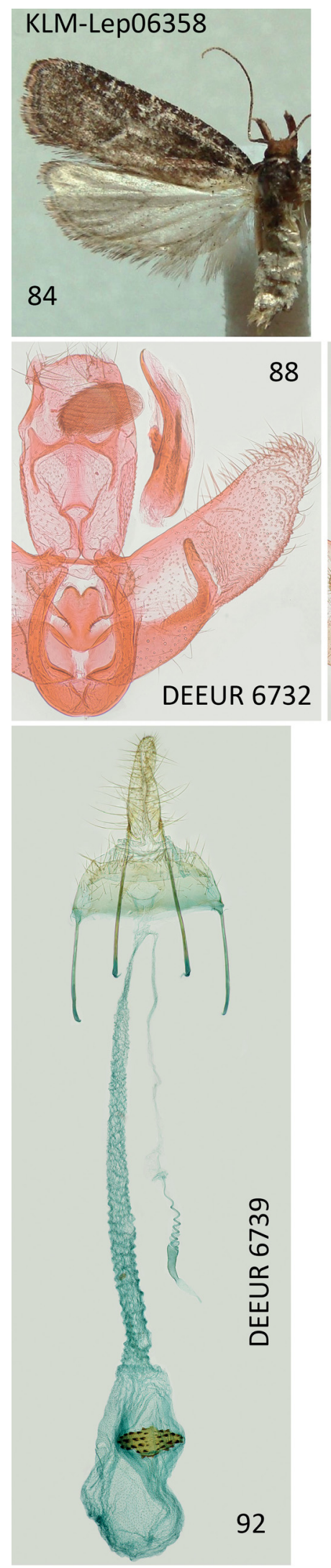

95
DEEUR 5896

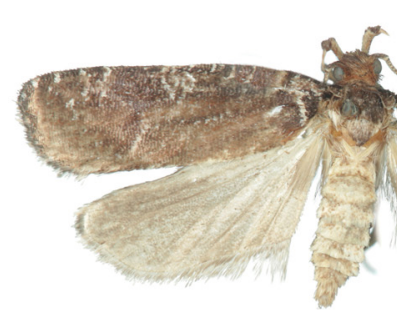

85

\section{DEEUR 6875}

86
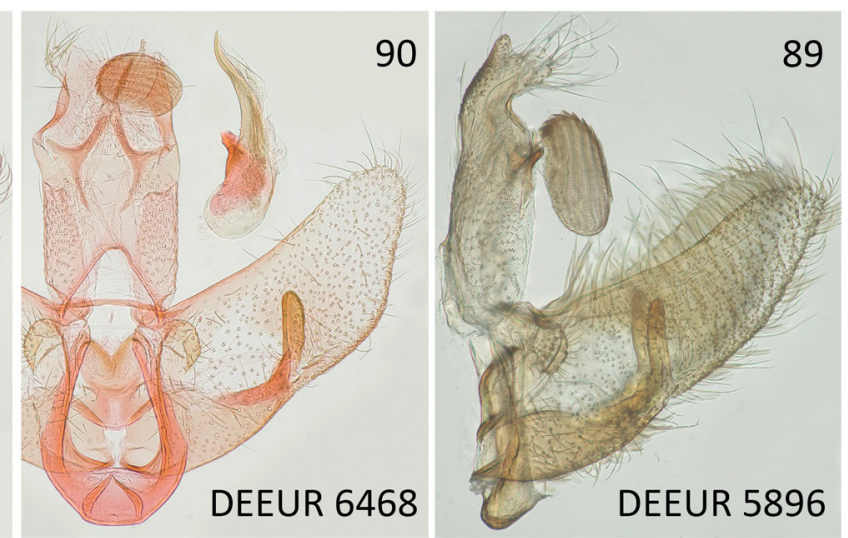

DEEUR 0910

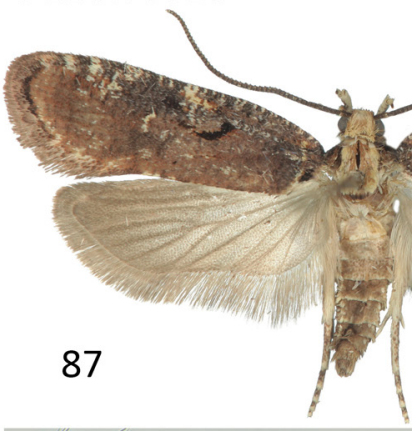

91
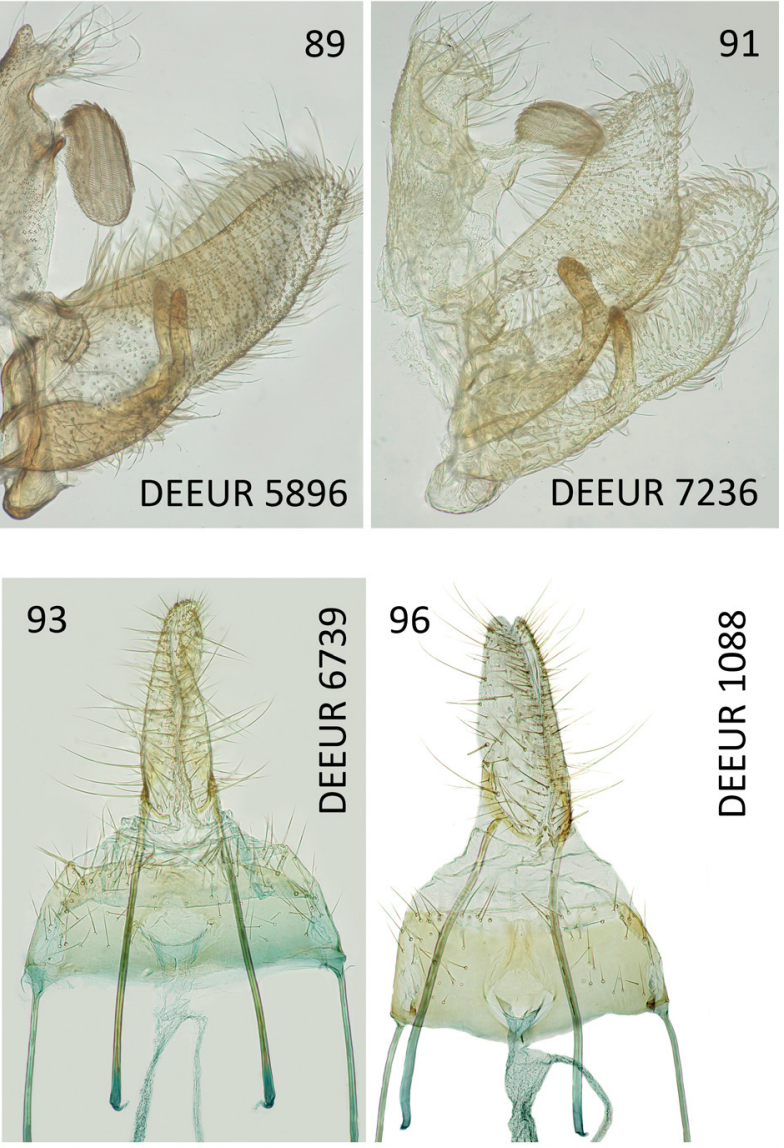

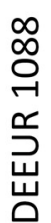

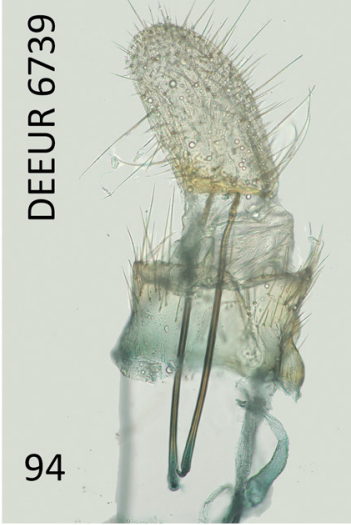

$\infty$
$\infty$
0
$\ddots$
$\stackrel{口}{\supset}$
岀
○े

97

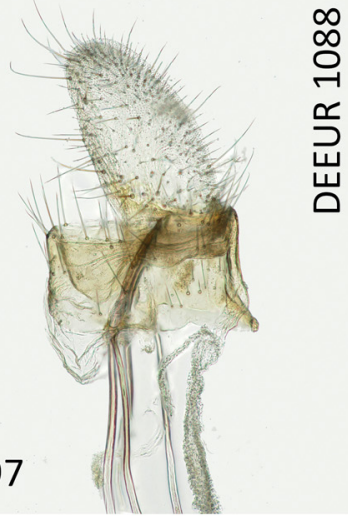

Figs 84-97. Comparison of Agonopterix rimulella (Caradja, 1920) and A. liturosa (Haworth, 1811). 84-85 - habitus of A. rimulella: 84 - Russia, Altai Mts., Chemal, 8.viii.2016, Ch. Wieser leg. (LMK); 85 - Russia, Primorje, Gorno-Taezhnoye, 2.ix.1973, Kuznetzov leg. (HNHM); 86-87- habitus of $A$. liturosa: 86 -Austria, Schwarzau am Steinfeld, 5.v.-4.vi.2011, e. 1. Hypericum perforatum, P. Buchner leg. (RCPB); 87 - Austria, Wegscheid, 16.vi.1931, J. Klimesch leg. (ZSM); 88-89 - male genitalia of A.rimulella: 88 - Russia, Gorno-Taezhnoye, 18 km SE Ussurijsk, 31.vii.2004, K. Larsen leg. (RCKL); 89 - Russia, Gorno-Taezhnoye, 2.ix.1973, Kuznetzov leg. (HNHM); 90-91 - male genitalia of A. liturosa: 90 - Russia, Cheliabinsk District, Moskovo, 2.vi.2004, K. Nupponen leg. (RCKN); 91 - Austria, Duerrenstein-Eisenstadthuette, 1480 m, 26.ix.2017, W. Stark leg. (RCWS); 92-94-female genitalia of A. rimulella: Russia, Gorno-Taezhnoye, Ussurijsk, 31.vii.2002, K. Larsen leg. (RCKL); 95-97-female genitalia of A. liturosa, Bulgaria, Stara Planina, Zlatica, 24.vii.2011, L. Srnka leg. (RCLS). (88, 90, 92-93, 95-96 - standard preparation; 89, 91, 94, 97 - free floating, lateral view). 

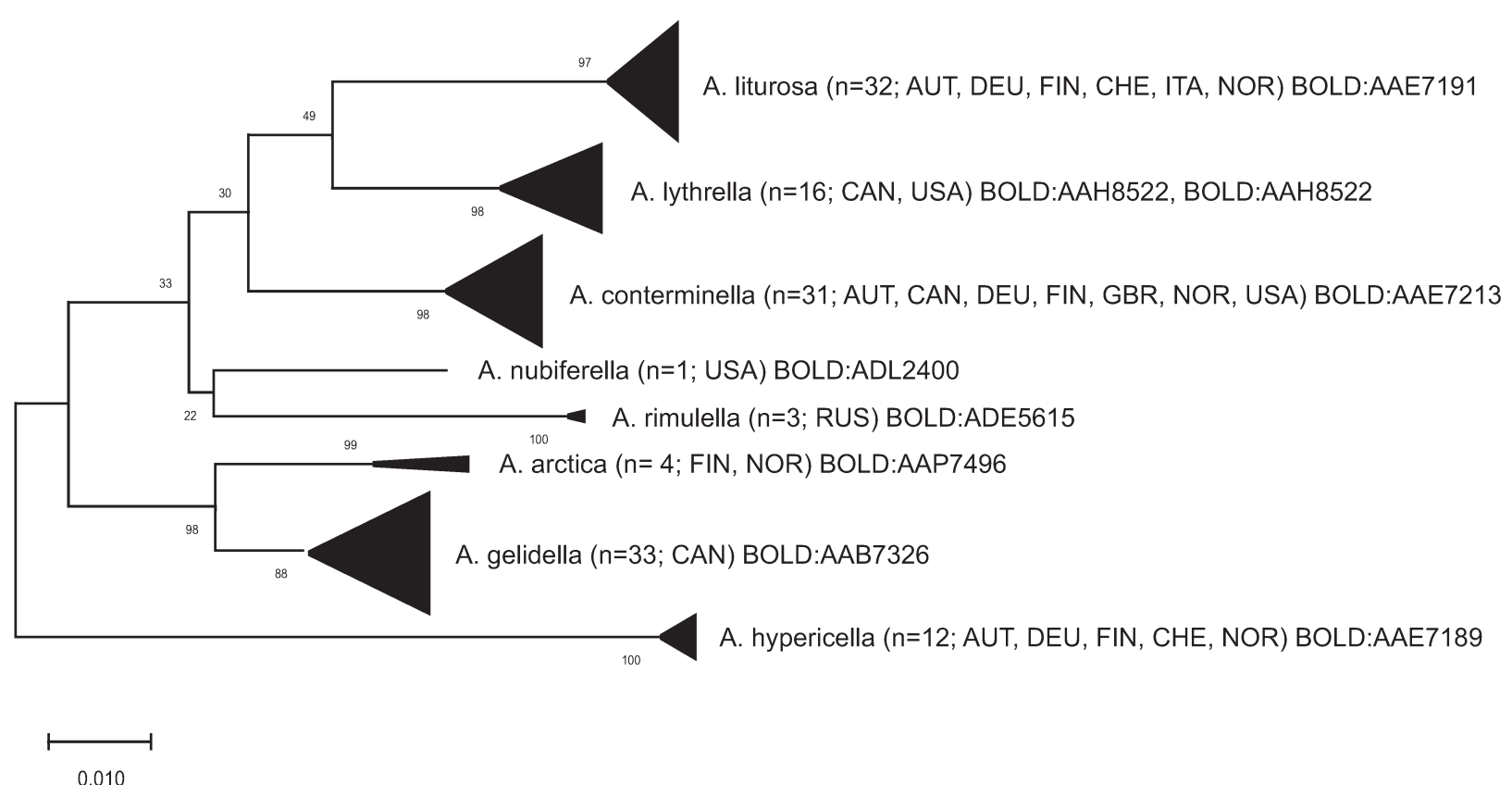

Fig. 98. Maximum likelihood tree of the A. hypericella species group (data from BOLD).

Agonopterix species. Intraspecific barcode distances are low throughout, interspecific distances are above average of the rest of this genus. Based on the p-distance of the sequences, the following species have been found to be closest to $A$. rimulella: $A$. nubiferella (Walsingham, 1881) $5.2 \%$, A. conterminella (Zeller, 1839) 5.8\%, A. gelidella (Busck, 1908) 6.1\%, A. lythrella (Walsingham, 1889) $6.15 \%$, A. arctica (Strand, 1902) 6.4\%, and A. liturosa $7.2 \%$ (see Fig. 98). At least based on molecular data, $A$. liturosa is far from being the closest related species to $A$. rimulella or even conspecific with it. With this background, genitalia have been re-examined and they clearly show that A. rimulella and A. liturosa are not identical.

In male genitalia at least four features show differences, as compared in Table 1 (see also Figs 88-91). Agonopterix conterminella is the closest Palaearctic species in p-distance but feeding on Salix L. (and therefore clearly not conspecific with the Hypericum-feeders) and included to show that genitalia differences are in general small and delicate in this group, so the small differences cannot serve as an argument for conspecificity. Finally, the fact that both $A$. liturosa and A. rimulella feed on Hypericum sp., also cannot serve as an argument for conspecificity. There are further species in this group which are definitely not conspecific, but also feed on species of this plant genus. To highlight this situation, a list of species of $A$. hypericella group with information about food plants is presented below.

Based on all indications presented above, and also in accordance with the general analysis and conclusions published by Mutanen et al. (2012), our conclusion is that A. liturosa rimulella (Caradja, 1920) has to be treated as a separate species $A$. rimulella (Caradja, 1920) stat. restit.

In the paper of HUEMER et al. (2017) it is presented as Depressaria sp.
List of Agonopterix species related to A. rimulella feeding predominantly on Hypericum and Salix:

Agonopterix arctica (Strand, 1902) (Salix, Palaearctic) A. conterminella (Zeller, 1839) (Salix, Holarctic)

A. gelidella (Busck, 1908) (Salix, Nearctic)

A. hyperella (Ely, 1910) (Hypericum, Nearctic)

A. hypericella (Hübner, [1817]) (Hypericum, Palaearctic)

A. liturosa (Haworth, [1811]) (Hypericum, Palaearctic)

A. lythrella (Walsingham, 1889) (Hypericum, Lythrum, Nearctic)

A. nubiferella (Walsingham, 1881) (Hypericum, Nearctic)

A. rhododrosa (Meyrick, 1934) (Hypericum, e.g. H. erectum, Palaearctic)

A. rimulella (Caradja, 1920) (Hypericum, Palaearctic)

\section{Agonopterix ustjuzhanini sp. nov. (Figs 99-112)}

Type material. Holotype: $\widehat{\delta}$ (NMPC): RUSSIA: Altai Republic: Aktash vill., $50^{\circ} 19^{\prime} 12^{\prime \prime} \mathrm{N} ; 87^{\circ} 36^{\prime} 00^{\prime \prime} \mathrm{E}$, grassy steppe, rocks, $1400 \mathrm{~m}$, 11.vii.2014, Barcode TLMF Lep 23279, gen. prep. DEEUR 6168, J. Šmpich leg. PARATYPES: $20 \hat{d}$ (NMPC, PBSA): the same locality as holotype but M. Dvořák leg.; 1 ( (NMPC): the same locality as holotype but 29.vi.2014, M. Dvořák leg.; 1 \& (NMPC): the same locality as holotype but 21.vi.2015, M. Dvořák leg. (gen. prep. DEEUR 6226 P. Buchner) (Barcode TLMF Lep 23318); Chulyshman valley, $45 \mathrm{~km} \mathrm{~N}$ of Ulagan vill., $51^{\circ} 01^{\prime} 03^{\prime \prime} \mathrm{N} ; 88^{\circ} 00^{\prime} 39^{\prime \prime} \mathrm{E}$, grassy steppe, rocks, $600 \mathrm{~m}, 27 .-28$. vi.2015, 1 (Barcode NMPC-LEP-0159), J. Šumpich leg. (NMPC); 1 $\hat{\jmath}$, the same locality but 4.-5.vii.2019, J. Šumpich leg. (NMPC); Belyashi (Dzhazator) env. (56 km SE), rocky steppe and mountain meadows near Tara river, $2400 \mathrm{~m}, 49^{\circ} 39^{\prime} 45^{\prime \prime} \mathrm{N}, 88^{\circ} 14^{\prime} 28^{\prime \prime} \mathrm{E}, 25 .-26 . v i i .2017,4$ o $^{\jmath}$ (Barcode NMPC-LEP-0158), J. Šumpich leg. (NMPC); Shebalino environs, $8 \mathrm{~km} \mathrm{~W}$ of Cherga village, $51.56^{\circ} \mathrm{N}, 85.48^{\circ} \mathrm{E}, 8 .-9$.vii.2019, 1 , J. Šumpich leg. (NMPC); Tabozhok valley, 10 km NE Kosh-Agach vill., Kurai Mts. Range, $2400 \mathrm{~m}, 50^{\circ} 05^{\prime} \mathrm{N}, 88^{\circ} 45^{\prime} \mathrm{E}$, 2.viii.2016, $1 \delta^{\widehat{\lambda}}$ (TLMF Lep 21240), P. Huemer \& B. Wiesmair leg. (TLMF); Kosh-Agach distr., Ukok Plateau, northern part, $2400 \mathrm{~m}, 49^{\circ} 30^{\prime} \mathrm{N}, 88^{\circ} 06^{\prime} \mathrm{E}$, 5.viii.2016, 1 $\widehat{o}$ (KLM Lep 06357), Ch. Wieser leg. (LMK). BuRYatia: Hamar Daban 

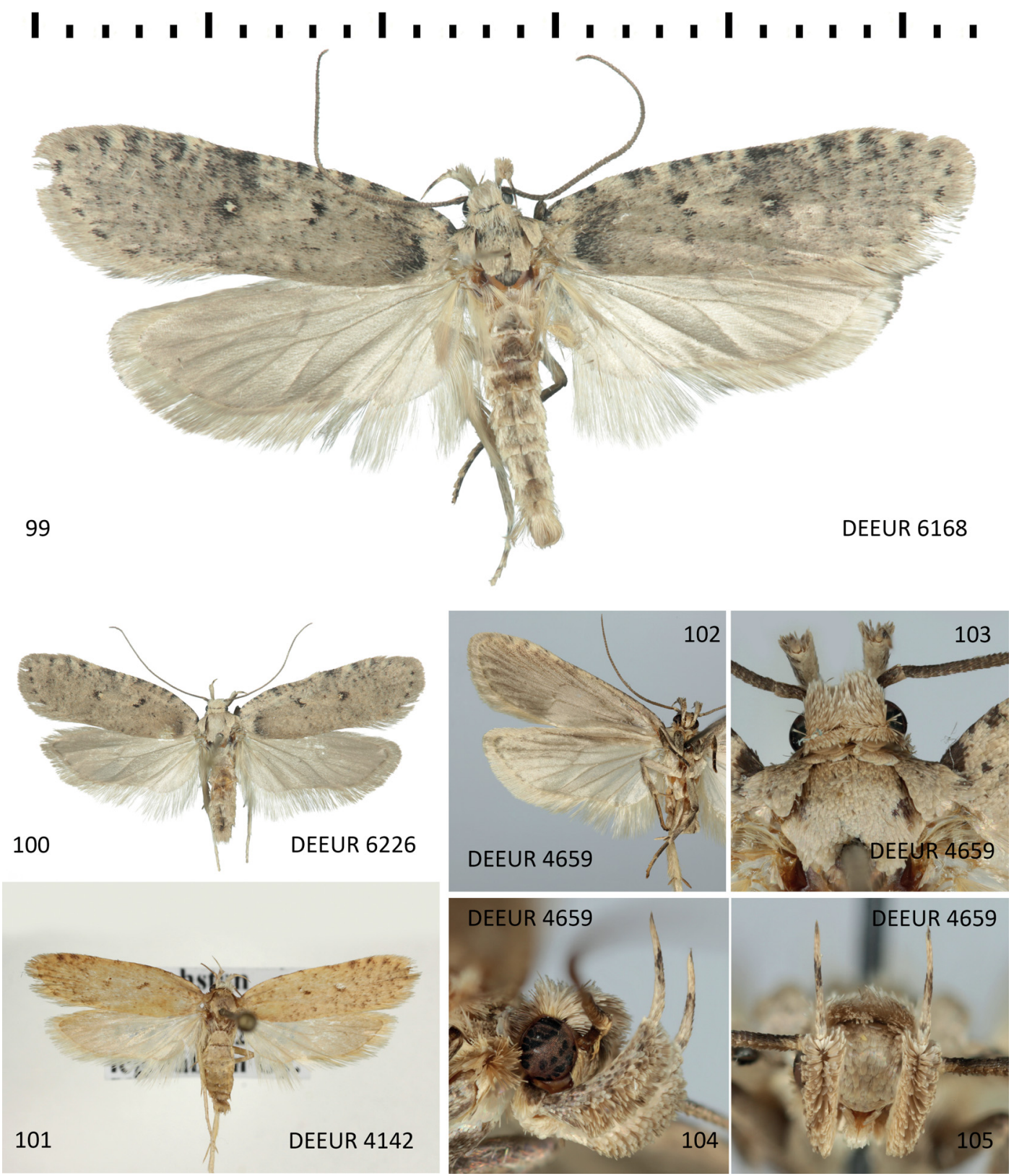

Figs 99-105. Agonopterix ustjuzhanini sp. nov. 99 - holotype, Russia, Altai Mts., details in the text; 100-105 - paratypes, details in the text: 100-101 habitus: 100 - Russia, Altai Mts., Aktash; 101 - Kazakhstan, Kokpek; 102-105 - Russia, Buryatia, Hamar Daban Mts., Murtoy River, Gusinoe Ozero vill., 19.vi.2002, K. Nupponen leg. (TLMF): 102 - underside; 103 - detail of head and thorax; 104-105 - labial palpi: 104 - lateral view; 105 - frontal view.

Mts., Murtoy River near Gusinoe Ozero village, $51.2^{\circ} \mathrm{N}, 106.18^{\circ} \mathrm{E}$, 19.vi.2002, 1 đै (TLMF Lep 19213), gen. prep. DEEUR 4659, K. Nupponen leg. (RCKN). KAZAKHSTAN: Kokpek, $43.45^{\circ} \mathrm{N}, 78.66^{\circ} \mathrm{E}$, 1.x 1994, 1 ㅇ (Barcode NGS-29197-E01), gen. prep. DEEUR 4142, Gy. Fabian leg. (RCGF); Katutau Mts., Konyrolen River, $44.21^{\circ}$ N, $79.33^{\circ}$ E, 2.x.2015, 1 ठै (Barcode TLMF Lep 19326), gen. prep. DEEUR 4680, K. Nupponen leg. (RCKN).

Description. Adult (Figs 99-105). Wingspan 24.0-27.5 $\mathrm{mm}$. Head grey with brownish tinge, scales tipped whitish, face grey. Labial palp grey, segment 2 paler on inner side, with brownish tinge ventrally and speckled dark grey on outer side, segment 3 with partial dark grey ring at two-thirds and tip. Antenna fuscous. Thorax pale grey, becoming grey-brown in anterior third, tegulae pale grey. Forewing grey with brown tinge, with scattering of dark fuscous scales; basal field pale grey, edged by broad dark fuscous fascia in dorsal two-thirds, costa with blackish dot at base, costal spots blackish, extending along whole length of costa with tendency to be smaller and more clearly contrasting against ground colour in basal half; terminal spots blackish; oblique dots blackish, another at end of cell, consisting of white centre with blackish scales entirely surrounding it or these blackish scales weaker to absent on proximal side; diffuse spot on costal margin of cell dark grey, of variable size, sometimes indistinct and confluent with costal spots; plical dot indistinct; fringes pale greyish brown, with two fringe lines, distal one indistinct. Hindwing greyish brown, a little darker towards termen, with a few dark grey spots between veins, fringes similar to ground colour with two or three indistinct fringe lines. Abdomen grey. 

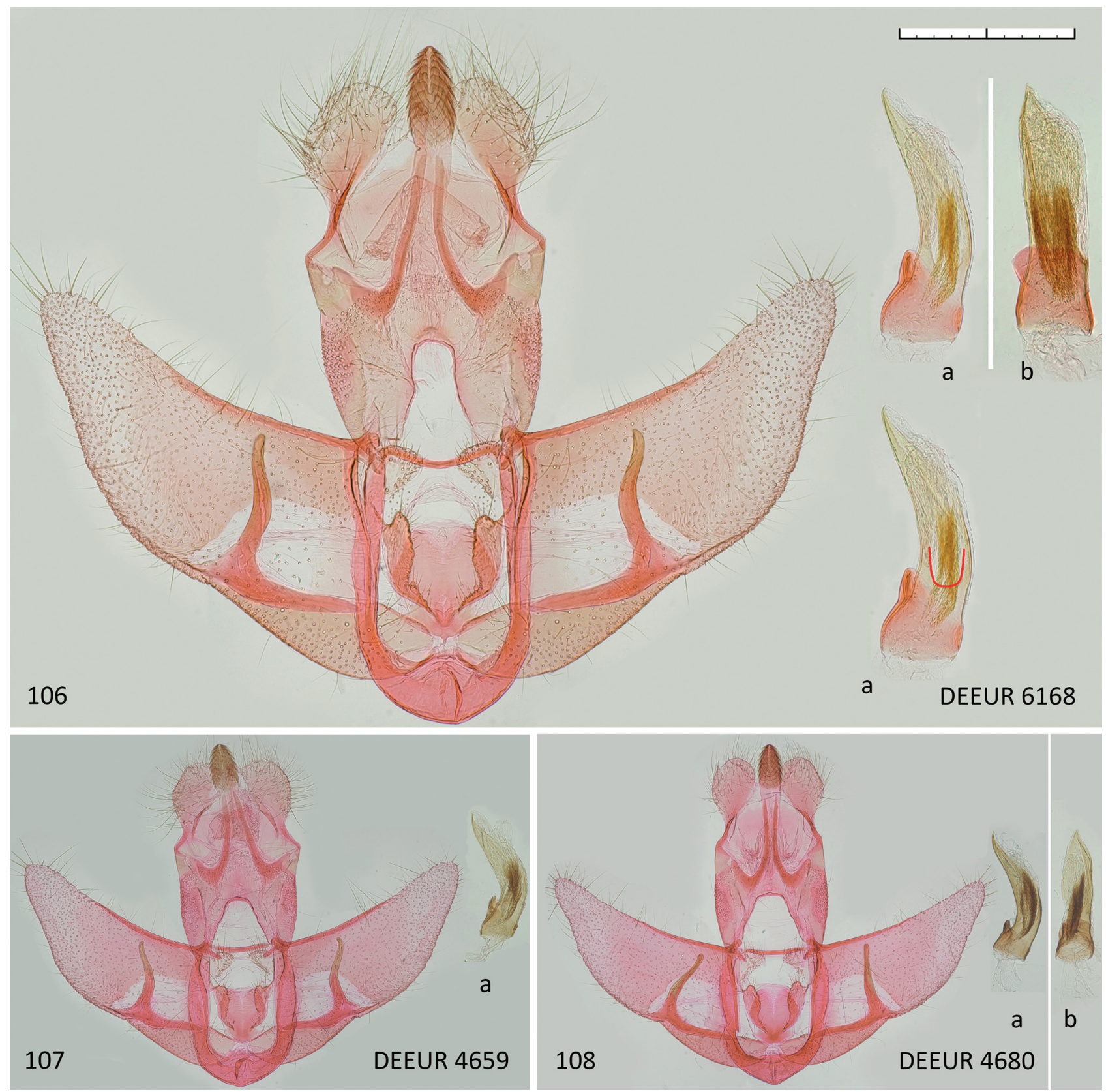

Figs 106-108. Male genitalia of Agonopterix ustjuzhanini sp. nov. 106 - holotype, Russia, Altai Mts., details in the text; 107-108 - paratypes, details in the text, valva-complex to show intraspecific variability, especially in shape of cuiller: 107 - Russia, Altai Mts., data as figs 102-105; 108 - Kazakhstan, Kokpek, details in the text; a - aedeagus in lateral view (basal edge of pale area highlighted red); $\mathrm{b}-$ aedeagus in ventral view. Scale bar $=1 \mathrm{~mm}$.

Variation. We examined one specimen with grey or brownish grey colour entirely replaced by warm yellowish brown (Fig. 101).

Male genitalia (Figs 106-108). Socii medium-sized, broadly elliptic, $0.4-0.5 \mathrm{~mm}$ wide and $0.6-0.7 \mathrm{~mm}$ long, uncus triangular, indistinct, gnathos elliptic, medium-sized, $0.25-0.30 \mathrm{~mm}$ wide and $0.45-0.55 \mathrm{~mm}$ long, overtopping socii in standard preparation by about third to half of its length. Transtilla narrow, not widened medially, transtilla lobes semi-elliptic, $0.3 \mathrm{~mm}$ wide and long, gap between them $0.15-0.20 \mathrm{~mm}$. Anellus medium-sized, round, length/ breadth $0.6 / 0.6 \mathrm{~mm}$, gap to transtilla $0.3-0.4 \mathrm{~mm}$, caudal margin with distinct V-shaped central incision filled with thin membrane, anellus lobes medium-sized, narrow elliptic, with distinct bulge towards transtilla which gives them semicordate appearance, length $0.5-0.6 \mathrm{~mm}$, width $0.15-0.20$ $\mathrm{mm}$. Valva about $2.7-3.0 \mathrm{~mm}$ long, $1.2-1.4 \mathrm{~mm}$ broad at base, tapering to about $1.0 \mathrm{~mm}$ at origin of cuiller, then widening a little before evenly tapering to its rounded tip. Cuiller rather thin, $0.1 \mathrm{~mm}$ diameter in basal half, tapering to $0.05-0.07 \mathrm{~mm}$ in distal half, slightly S-shaped (Fig. 107) or sometimes only slightly bent outward (Fig. 108), ending shortly (about $0.1 \mathrm{~mm}$ ) before costa, blunt. Aedeagus 1.3-1.4 $\mathrm{mm}$ long, bent $\left(40-60^{\circ}\right)$ in lateral view, diameter $0.3 \mathrm{~mm}$, sclerotised basal parts with total length of about $0.4 \mathrm{~mm}$, free section about $0.15 \mathrm{~mm}$, in lateral view (basal process and concave edge must be on left side!) with distinct, U-shaped area paler than the rest, exceeding end of free section of 


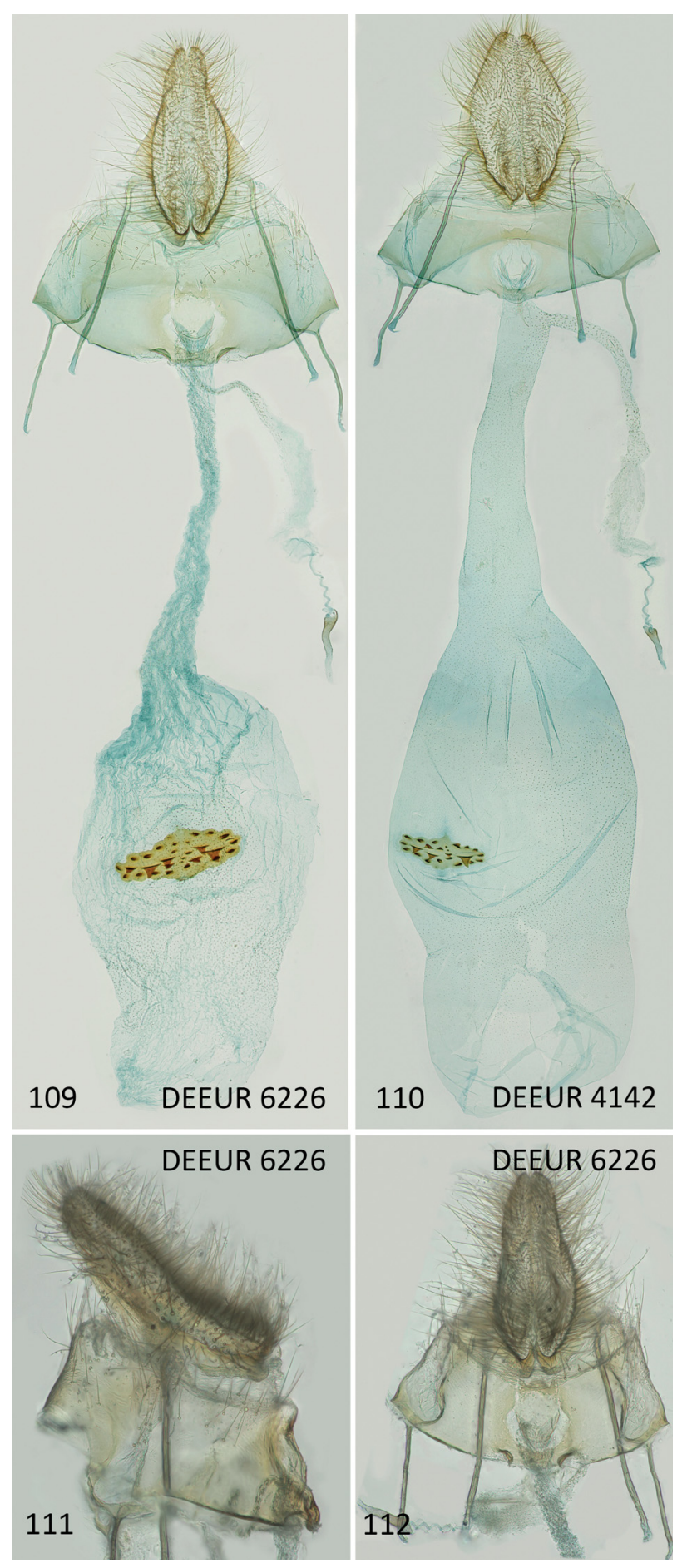

Figs 109-112. Female genitalia of Agonopterix ustjuzhanini sp. nov., details in the text. 109 - Russia, Altai Mts., Aktash; 110 - Kazakhstan, Kokpek; 111-112 - data as fig. 109, detail papillae anales and segment VIII, free floating (111 - lateral view, 112 - ventral view).

basal sclerotisation (Fig. 106, highlighted in the copy of aedeagus in lateral view, important feature in male genitalia to separate from similar species, details under diagnosis). In ventral view about as wide as in lateral view, but somewhat expanded at about $3 / 5$ from base before tapering to sharp tip, free part of basal sclerotisation about as broad as aedeagus and with convex ending. Vesica (uneverted) with numerous tiny cornuti in 2 or 3 not clearly separable groups of about $1 / 2$ of aedeagus length.
Female genitalia (Figs 109-112). Papilla analis about $1.5 \mathrm{~mm}$ long and $0.4 \mathrm{~mm}$ broad in lateral and $0.6 \mathrm{~mm}$ in ventral view (refers to unembedded genitalia), posterior apophysis $1.6 \mathrm{~mm}$. Sternite VIII $0.8 \mathrm{~mm}$ long, maximum width $2.3 \mathrm{~mm}$, anterior apophysis $0.6-0.7 \mathrm{~mm}$.

Distal edge of sternite VIII medially with U-shaped excavation of about two-thirds of ostium width, proximal edge of sternite VIII evenly concave, with $0.15-0.20 \mathrm{~mm}$ long fold on either side, distance between inner ends of folds $0.30-0.35 \mathrm{~mm}$, ostium slightly proximal to middle of sternite VIII, round with diameter of about $0.3 \mathrm{~mm}$, ductus bursae about 2.5-3.0 mm long, corpus bursae elliptic, 3.0-4.0 mm long and transverse diameter up to $2.0 \mathrm{~mm}$, signum medium-sized with width/length ratio of about $0.7-1.0 / 0.3-0.4$ $\mathrm{mm}$, about 15-20 small teeth at its margin and about 4-6 larger, triangular teeth along transverse axis. Origin of ductus spermathecae $0.2 \mathrm{~mm}$ from ostium and ending with about 4 turns, ductus and corpus bursae covered with numerous tiny dots, apart from this without specifically distinct constant structures. Details of ductus bursae reflect life history, especially whether the specimen has mated or not, rather than specific features, which makes a detailed description useless (compare Figs 109-110).

Differential diagnosis. Externally, the new species shares the basic wing patterns mainly with Agonopterix adspersella (Kollar, 1832) and A. thapsiella (Zeller, 1847), and other closely related species, namely A. leucadensis (Rebel, 1932), A. cervariella (Constant, 1884), A. olusatri Corley \& Buchner, 2019, and A. cadurciella (Chrétien, 1914). With wingspan up to $27.5 \mathrm{~mm}$ the average size exceeds all other species, but for determination this is of limited use because there is an overlap between 24 and $26 \mathrm{~mm}$ with other species; in addition, exceptionally small specimens can be found in every species. The new species is most similar to $A$. adspersella / A. thapsiella (these two species are treated as a species pair here, because without information about larval features and food plant it is not possible to determine every specimen of this pair to species level; it is not the intention of this paper to solve this problem, although some details are discussed further below). Reddish elements, especially in oblique dots and central dot with reddish brown instead of blackish scales, are often developed in A. adspersella / A. thapsiella but have not been found in A. ustjuzhanini. Besides this, many specimens of this very variable species pair are separable from $A$. ustjuzhanini only by dissection. In $A$. leucadensis, white scales in the central dot are usually completely absent, but they are rarely present as in $A$. ustjuzhanini, providing an overlap in external features in occasional specimens. However, with distribution of $A$. leucadensis restricted to Greece, as far as known, the risk of confusing these two species is low. In A. cervariella, the third segment of labial palp is pale flesh-red without black elements except for a few black scales at the very tip, and forewings show a flesh-red tinge, which helps to separate A. cervariella from all the other species mentioned here. In A. olusatri, the white scales in central dot are usually absent or only a few if present, and the pale colour of the basal field does not extend along costa, while in A. ustjuzhanini it tends to continue along the basal half of costa. Agonopterix 
cadurciella is comparatively easily separable externally by forewings with very pale ground colour, covered with diffuse, medium brown patches, best seen in Figs 113 and 115 , but also in this species intraspecific variability makes it impossible to determine every specimen based only on external appearance. One example is a specimen (Fig. 114) with brown areas very extended and the interspersed black scales more numerous than usual. Another is a specimen (Fig. 116) where features usually distinct for A. cadurciella are nearly absent, and only the fact that it was reared from Seseli cf. tortuosum L. indicated that it could be A. cadurciella, which was confirmed by dissection.

In male genitalia, the new species differs from all the compared species in distinctly narrower socii and anellus lobes. Similar shape of cuiller is found in A. cadurciella only, but in this species it is much longer and clearly exceeds the costa of valva. The extent of pale area on the left side of aedeagus is a good feature to distinguish the new species from $A$. adspersella / thapsiella, where it is much smaller, and from A. olusatri, where it is clearly larger. Agonopterix leucadensis is best distinguished by the shape of cuiller which is unique in this group by being sharply hooked at its tip, and A. cervariella by the shape of aedeagus in lateral view, which is also unique in this group by being remarkably narrow with a sharp angle in its middle and the free section of basal sclerotisation reaching this bend.

Diagnosis based on female genitalia is shown in Table 2. Molecular data. BIN BOLD: ADC2512 ( $\mathrm{n}=10,0$ public, 6 from Altai). The average intraspecific divergence of the barcode region is $0.32 \%$ (maximum $0.80 \%$ )

Etymology. The species name is dedicated to Petr Ustjuzhanin (Novosibirsk, Russia), an expert on Pterophoridae, who was helpful to the second author during his trips to Russia. Biology. Food plant unknown so far, but with all species of the $A$. adspersella group feeding on Apiaceae, it is likely the same with $A$. ustjuzhanini.

Distribution. Russia (Buryatia, the Altai Republic), Kazakhstan (Kokpek, Katutau Mts.).

Remarks. In the past, there was some confusion between related taxa of the $A$. adspersella group to which $A$. ustjuzhanini belongs. The "Agonopterix adspersella group" can be understood in different ways: as a group of very closely related species comprising $A$. adspersella, $A$. thapsiella and $A$. chironiella (Constant, 1893), but also as a broader group consisting of the species listed below. Specimens belonging to the first narrow group ( $A$. adspersella group sensu stricto) cannot always be determined to species level if no information about the preimaginal stages is available. Specimens of the broader group (A. adspersella group sensu lato) may be very similar and undeterminable externally, but with genitalia dissection or barcoding, a safe determination is possible. Anyway, during identification all the species of the broader group should be kept in mind, and we include them for comparison.

A detailed treatment of species not found in the Altai Mts. in a paper dealing with the fauna of this region may be puzzling. But the description of A. ustjuzhanini brought to light so many doubtful and incorrect information about the $A$. adspersella group in actual literature that it was impossible to present a sufficient differential diagnosis without a closer look at this group. Also, we realised that features so far used for determination show a geographical variation and therefore it is essential to expand the look on the whole range of these species, which in this case inevitably leads far away from the Altai Mts. Finally, essential features for species delimination are found in preimaginal stages, especially the colour of thoracic legs of mature larvae (Figs 142-145). Information about corresponding larval and imaginal features (both external and in genitalia) is insufficient, which makes it difficult to impossible to discern adult features which represent only intraspecific variability from features which are of diagnostic value, thus leaving a considerable number of adults that lack information about larval features undeterminable at the moment. An additional reason to present larval features is motivation to fill this gap in the future.

\section{Comments on the taxonomic position of problematic taxa from the Agonopterix adspersella group}

Agonopterix adspersella (Figs 117, 124, 131, 142) was described in 1832 by Vincenz Kollar from "Mödling und Baden", an area south of Vienna in Austria, characterised

Table 2. Differential diagnosis of species from the Agonopterix adspersella group based on female genitalia.

\begin{tabular}{|c|c|c|c|c|c|c|}
\hline Character & A. ustjuzhanini & $\begin{array}{l}\text { A. adspersella / } \\
\text { thapsiella / } \\
\text { chironiella }\end{array}$ & A. cadurciella & A. leucadensis & A. cervariella & A. olusatri \\
\hline $\begin{array}{l}\text { position of ostium } \\
\text { in sternite VIII }\end{array}$ & $\begin{array}{l}\text { slightly proximal } \\
\text { to the centre }\end{array}$ & distal to the centre & distal to the centre & distal to centre & in the centre & in the centre \\
\hline $\begin{array}{l}\text { structures in the } \\
\text { anterior edge of } \\
\text { sternite VIII }\end{array}$ & $\begin{array}{l}\text { a pair of folds with } \\
0.30-0.35 \mathrm{~mm} \\
\text { distance of inner } \\
\text { edges }\end{array}$ & $\begin{array}{l}\text { a pair of folds with } \\
0.15-0.20 \mathrm{~mm} \\
\text { distance of inner } \\
\text { edges }\end{array}$ & $\begin{array}{l}\text { no distinct folds, } \\
\text { but a trapezoid } \\
\text { excavation in the } \\
\text { middle }\end{array}$ & $\begin{array}{l}\text { no folds, slightly } \\
\text { concave in the } \\
\text { middle: sternite } \\
\text { VIII very long }\end{array}$ & $\begin{array}{l}\text { a pair of folds with } \\
0.25-0.30 \mathrm{~mm} \\
\text { distance of inner } \\
\text { edges }\end{array}$ & $\begin{array}{l}\text { a pair of folds with } \\
0.6 \mathrm{~mm} \text { distance of } \\
\text { inner edges }\end{array}$ \\
\hline $\begin{array}{l}\text { structures in the } \\
\text { caudal edge of } \\
\text { sternite VIII }\end{array}$ & $\begin{array}{l}\text { excavated in the } \\
\text { middle }\end{array}$ & $\begin{array}{l}\text { straight or slightly } \\
\text { bulged in the } \\
\text { middle }\end{array}$ & $\begin{array}{l}\text { straight or slightly } \\
\text { bulged in the } \\
\text { middle }\end{array}$ & $\begin{array}{l}\text { straight or slightly } \\
\text { bulged in the } \\
\text { middle }\end{array}$ & $\begin{array}{l}\text { straight or slightly } \\
\text { excavated in the } \\
\text { middle }\end{array}$ & $\begin{array}{l}\text { distinctly } \\
\text { excavated in the } \\
\text { middle }\end{array}$ \\
\hline $\begin{array}{l}\text { structures in ductus } \\
\text { bursae }\end{array}$ & $\begin{array}{l}\text { diagnostic features } \\
\text { absent }\end{array}$ & $\begin{array}{l}\text { zone of transverse } \\
\text { folds where it } \\
\text { meets corpus } \\
\text { bursae } \\
\text { (Figs } 11 \mathrm{c}, \mathrm{d})\end{array}$ & $\begin{array}{l}\text { fine irregular folds } \\
\text { in caudal half } \\
\text { (Fig. 11a), fine } \\
\text { longitudinal folds } \\
\text { in anterior half } \\
\text { (Fig. 11b) }\end{array}$ & $\begin{array}{l}\text { anterior } 1 / 4 \text { with } \\
\text { spiral ridges like } \\
\text { a thick rope (Fig. } \\
11 \mathrm{e} \text { ) }\end{array}$ & $\begin{array}{l}\text { caudal } 1 / 4 \text { with } \\
\text { spiral ridges like } \\
\text { a thick rope (Fig. } \\
\text { 11f) }\end{array}$ & $\begin{array}{l}\text { diagnostic features } \\
\text { absent }\end{array}$ \\
\hline
\end{tabular}



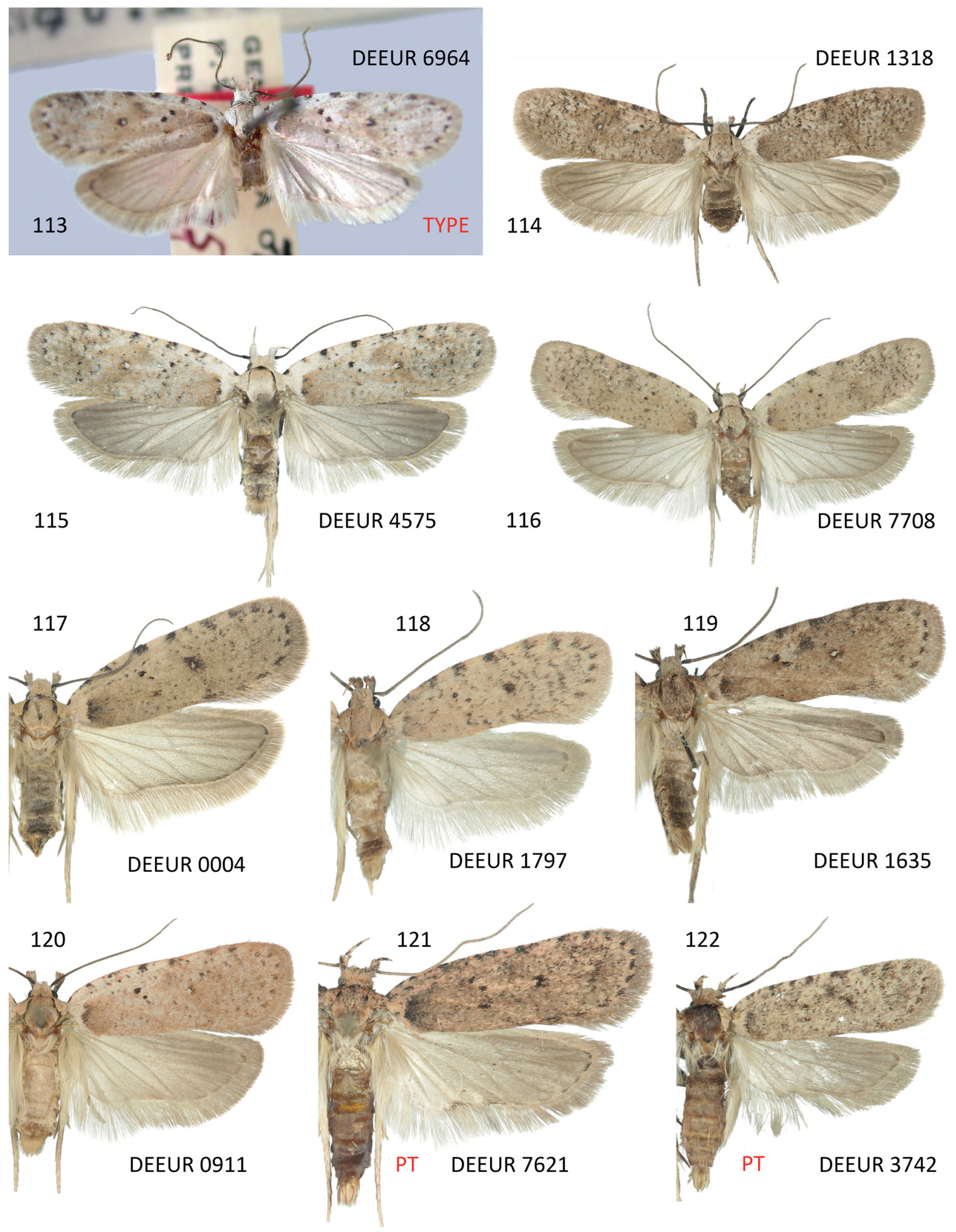

Figs 113-122. Comparison of species from the Agonopterix adspersella group based on external appearance. 113-116 - A. cadurciella (Chrétien, 1914): 113 - type specimen ex coll. Chrétien (MNHN); 114 - Hungary, Bucka hegy, 7.vi.2008, I. Richter leg. (RCIR); 115 - Croatia, Karkobag, 5.vi.2015, J. Junnilainen leg. (RCJJ); 116 - France, Alpes Maritimes, Fontan, Maurion, 12.vii.2013, larva from "fadenförmige Apiaceae" (cf. Seseli tortuosum), P. Sonderegger leg. (NMBE with code GBIFCH00723210). 117-A. adspersella (Kollar, 1832), Austria, Lower Austria, Scheiblingkirchen, 25.iv.-25.v.2008, e.1. Bupleurum falcatum, P. Buchner leg. (RCPB). 118 - A. leucadensis (Rebel, 1932), Greece, Peloponnes, Leonidio, 18.v.2009, T. Mayr leg. (RCTM). 119 - A. chironiella (Constant, 1893), Italy, Mt. Vulture, 16.vi.1967, e.1. Opopanax chironium, Hartig leg. (TLMF). 120 - A. cervariella (Constant, 1884), Italy, Trento Sopra Sasso, 5.vi.1949, e.1. Peucedanum cervaria, J. Klimesch leg. (ZSM). 121-122 - A. olusatri Corley \& Buchner, 2019, paratypes: 121 - Spain, Canary Islands, Lanzarote, El Bosquecillo, 6.xi.2018, C. Hviid \& B. Skule leg. (ZMUC); 122 - Malta North, Marfa Ridge, 9.iv.2004, B. Skule leg. (ZMUC). 

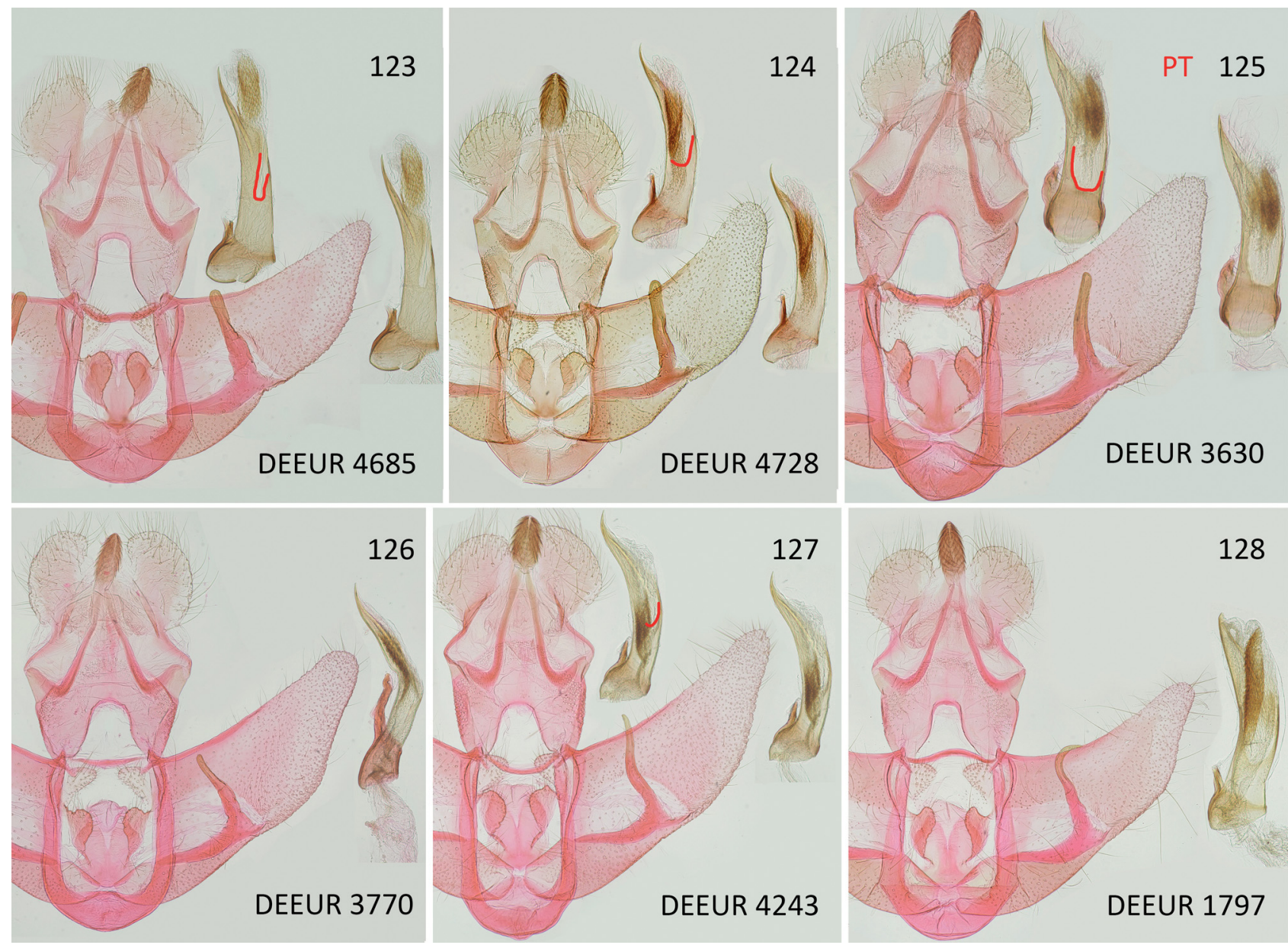

Figs 123-128. Comparison of species from the Agonopterix adspersella group based on male genitalia. 123 - A. thapsiella (Zeller, 1847), Greece, Crete, Ideon Andron, 23.vii.2011, T. Nupponen leg (RCKN); 124 - A. adspersella (Kollar, 1832), Italy, Abruzzo, Cocullo, 1.x.2014, T. Nupponen leg (RCKN); 125 - A. olusatri Corley \& Buchner, 2019, paratype, Greece, Crete, north of Lassithi, Agia Joannis, 19.v.2000, W. Ruckdeschel leg. (TLMF); 126 - A. cervariella (Constant, 1884), France, Cannes, without date, ex coll. C.S. Larsen (ZMUC); 127 - A. cadurciella (Chrétien, 1914), Hungary, without further data (NHMW); 128 - A. leucadensis (Rebel, 1932), data as fig. 118.

by limestone hills and xerothermic climate. No information is given about food plant and appearance of the larva.

In NHMW there are several specimens under $A$. adspersella, matching the original description and collected in the type area. One of them may be the type specimen, although it is not quite clear. It has four labels, first is "Podevin", a collector from 19th century whose collection includes many specimens from other lepidopterists, second is "coll. Zell.", third is "adspersella Koll., Type" handwritten by Rebel, fourth is "adspersella Präparat 1" handwritten by Josef Klimesch. There is no further label data, neither date nor place. Klimesch reared specimens from larvae collected in 1935 in subalpine areas of "Grosser Pyhrgas", Upper Austria, on Athamanta cretensis. To clarify whether these specimens belong to A. amanthicella (Heinemann, 1870), reared from "Bupleurum foliatum" [sic!] and Meum athamanticum Jacq. from the Bavarian Alps, or to $A$. adspersella (Kollar, 1832), he dissected the type specimen from NHMW. The investigation revealed complete agreement with the genitalia of $A$. adspersella, and the specimens reared from Athamanta cretensis and A. amanthicella were subsequently synonymised with $A$. adspersella (KLIMESCH 1942). In the type area, larvae of $A$. adspersella are most often found on Bupleurum falcatum L.; further food plants there are Laserpitium siler L. and Seseli libanotis (L.) W.D.J.Koch. With the first pair of thoracic legs black, they match the description of larvae of A. feruliphila.

Agonopterix thapsiella (Zeller, 1847) (Figs 123, 137, 144) was described by Philipp Christoph Zeller from Sicily; larvae were collected from Thapsia garganica and a detailed description of the larva was given already by Zeller. The most important detail here is as follows: "Vorderbeine gelblich, braunfleckig" [= thoracic legs yellowish, with brown dots].

Agonopterix feruliphila (Millière, 1866) was described by Pierre Millière from Hyères (France, Var); larvae were collected from Ferula nodiflora Pall. and a detailed description of the larva is given. The most important detail here is "Les pattes antérieures sont testacées avec le dernier article noir et luisant; les dix autres pattes sont unicolores et la couronne est jaunâtre" [= thoracic legs are yellowish brown with the last segment black and shiny; the other ten legs are unicolorous and the crown yellowish]. Agonopterix 


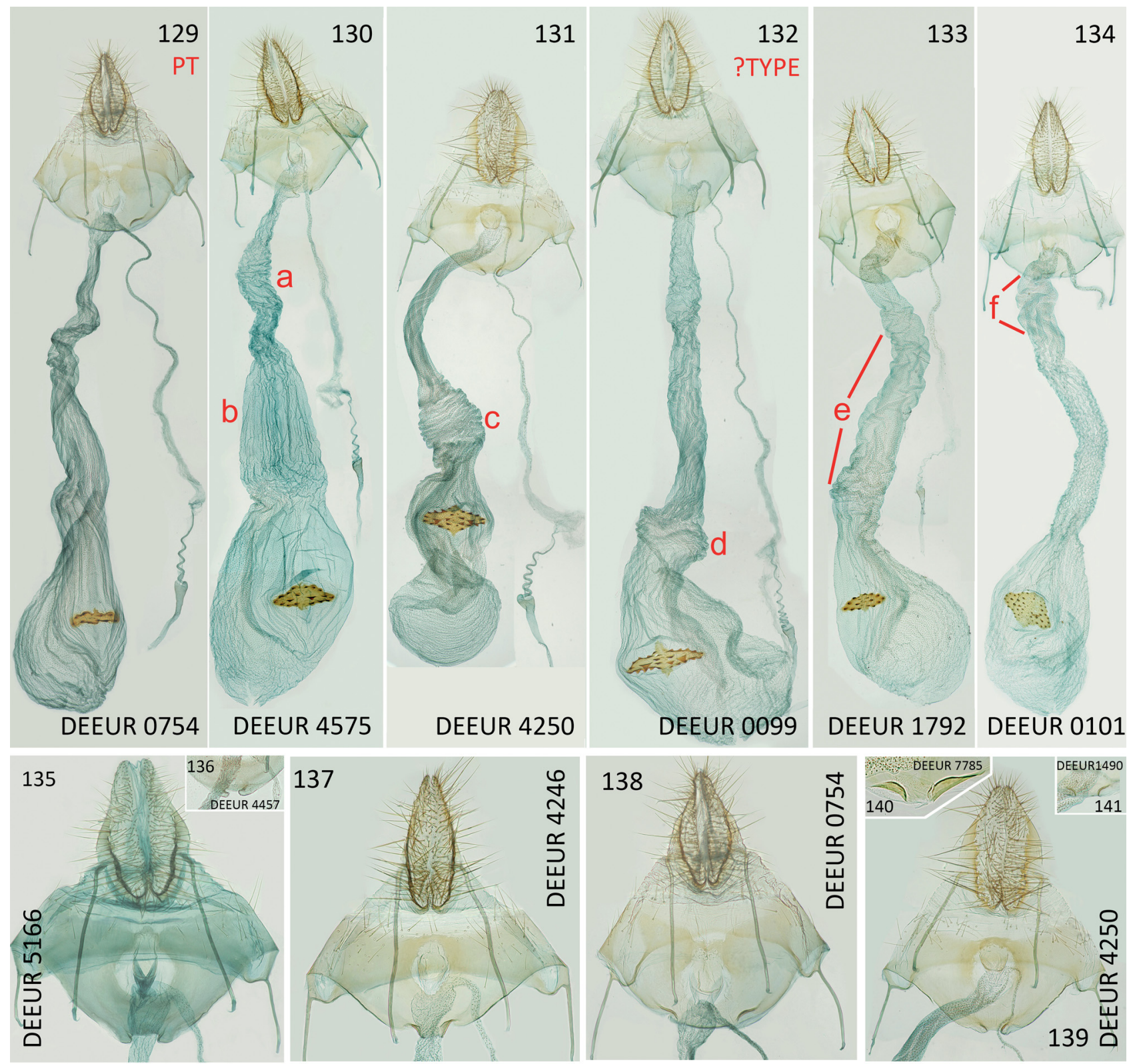

Figs 129-141. Comparison of species from the Agonopterix adspersella group based on female genitalia. 129-134 - general view: 129 - A. olusatri Corley \& Buchner, 2019, paratype, Spain, Malaga, Casares, 26.v.2011, P. Hale leg. (RCMC); 130 - A. cadurciella (Chrétien, 1914), Croatia, Karkobag, 5.vi.2015, J. Junnilainen leg. (RCJJ); 131 - A. adspersella (Kollar, 1832), Austria, Lower Austria, Gumpoldskirchen, 1.v.-21.vi.2012, e.1. Seseli libanotis, P. Buchner leg. (RCPB); 132 - A. chironiella (Constant, 1893), Gal. mer. [southern France], without date, ex coll. Constant (NHMW) [may belong to type series]; 133 - A. leucadensis (Rebel, 1932), data as fig. 118; 134 - A. cervariella (Constant, 1884), Austria, Vienna, Leopoldsberg, 22.vi.1927, e.1. Peucedanum cervaria, Preissecker leg (NHMW). 135-141 - details of papillae anales and segment VIII (inserted figs - detail of distal margin of sternite VIII)): 135-136 - A. cadurciella: 135 - France, St. Barnabe, 12.ix.1967, F. Dujardin leg. (TLMF); 136 - Italy, Gran Sasso, 15.vii.2010, P. Huemer leg. (TLMF); 137 - A. thapsiella (Zeller, 1847), Greece, Samos, Pyrgos, 10.v.2010, P. Sonderegger leg. (NMBE); 138 - A. olusatri, data as fig. 129; 139-141 - A. adspersella: 139 - data as fig. 131; 140 - Austria, Lower Austria, Scheiblingkirchen, e. 1. Bupleurum falcatum, 25.iv.-14.v.2008, P. Buchner leg. (RCPB); 141 - Austria, Lower Austria, Maiersdorf, e. 1. Laserpitium siler, 29.v.-24.vi.2011, P. Buchner leg. (RCPB).

feruliphila was synonymised with $A$. thapsiella by REBEL (1901). Investigation of larval features (RYMARCZYK et al. 2013) revealed that this conspecificity was incorrect. There are several differences in larvae reared from Thapsia garganica and those reared from Ferula nodiflora, most importantly in the colour of the first pair of thoracic legs, matching with the original descriptions of $A$. thapsiella and $A$. feruliphila. We fully agree with the conclusion that $A$. feruliphila is not a synonym of $A$. thapsiella. In the work of RyMARCZYK et al. (2013), genitalia of $A$. feruliphila and
A. thapsiella are also compared, and features for determination of not-reared specimens are proposed. We agree that some specimens can be determined as one or the other species without a doubt; however, there remain specimens where even dissection does not bring a clear result.

There is a wide field of open questions for the future. The range of food plants is not yet known, and there is also the possibility that larval features might be modified by different chemistry of food plant. Without a safe tool to identify each specimen it is impossible to discern spe- 

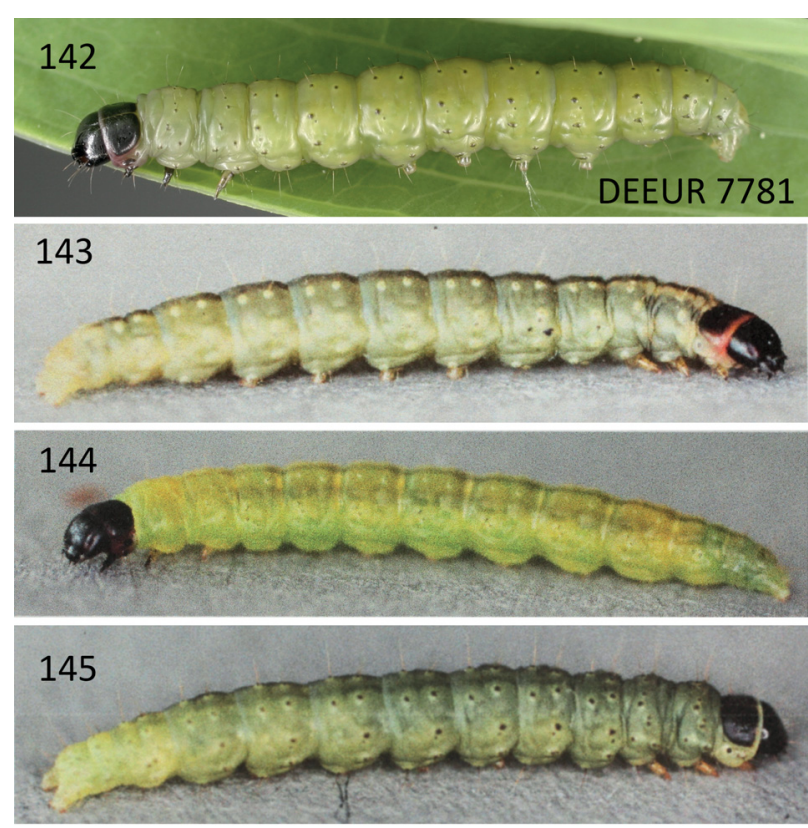

Figs 142-145. Comparison of larvae of the Agonopterix adspersella group s. str. based on food plant. 142 - Bupleurum falcatum as foodplant: A. adspersella, Lower Austria, Scheiblingkirchen, 25.iv.2008, (e.p. 6.v.2008), P. Buchner leg. (RCPB). 143-145 - Italy, Puglia, Gargano, 2.-10.iv.2016, P. Sonderegger leg. \& phot., reproduction from prints stored in NHBE: 143 - Thapsia garganica as food plant: A. thapsiella (Zeller, 1847); 144 - Scandix pecten-veneris as food plant: A. adspersella (Kollar, 1832); 145 -Opopanax chironium as food plant: A. chironiella (Constant, 1893).

cies-specific genitalia differences. Such an investigation must include the whole distribution range of $A$. adspersella / A. thapsiella, not only Europe, but also North Africa and the Asian part of its range. Until such investigations bring more clarity regarding this species pair, it is recommended to list doubtful specimens as A. adspersella / A. thapsiella. Agonopterix chironiella (Constant, 1893) (Figs 119, 132, 145) was described by Alexandre Constant from Alpes Maritimes (France); larvae were collected from Opopanax chironium W. D. J. Koch and a description of the larva is given, but without detailed information on the colour of thoracic legs. Imagines are not directly compared with other species, only the remark "J'estime qu'elle trouvera sa place naturelle prés de Depressaria applana" [= I think it will find its place near Depressaria applana - actually valid as $A$. heracliana (Linnaeus, 1758)], with an additional remark that the new species is distinct enough to exclude the risk of confusion. Agonopterix thapsiella is not mentioned at all. For a long time this species was only known from France and Italy. In 2019, it was found in Greece for the first time: "Peloponnes, Kalavryta, $800 \mathrm{~m}$, leg. larva 29.v.2019 from Opopanax chironium R. Seliger, e.p. 26.vi.2019 (RCRS, det. R. Seliger, conf. P. Buchner)". Although this species is externally distinct and usually safely discernable from $A$. thapsiella, larval and genital features (and also barcode) show it is very close to $A$. thapsiella. It must be kept in mind that worn out specimens may be inseparable from A. adspersella / A. thapsiella.

In the past, the name $A$. chironiella was used for an undescribed species, now valid as $A$. olusatri, so any determination or record of $A$. chironiella from outside of its known range may belong to $A$. olusatri. However, the unexpected discovery of $A$. chironiella in Greece shows it is likely to be more widespread.

Agonopterix cadurciella (Chrétien, 1914) (Figs 113-116, 127, 130, 135-136) was described by Pierre Chrétien from Causse de Gramat (France, Pyrenées). According to the description, larvae were collected from Hyoseris L. (Asteraceae) but it is likely that the food plant was misidentified: "Trois sujets obtenus en juillet de chenilles trouvées en juin, dans le Causse de Gramat, sur une Compositée défleurie, dont je n`ai pas gardé d`échantillon, mais qui m`a paru être un Hyoseris" [= Three moths obtained in July from caterpillars found in June, in the Causse de Gramat, on a withered plant, of which I did not keep a sample, but which appeared to be a Hyoseris.]. In our opinion Hyoseris (Asteraceae) is surely not the food plant. Also Hannemann (1958) had doubts about this Asteraceae association, because all species from the $A$. adspersella group feed on Apiaceae. Although A. cadurciella is distinct and usually determinable externally at first glance (comparison in Figs 113-116), its existence has been widely ignored. From all museums which were visited by the first author, beside MNHN, where the types are stored, only in TLMF a correctly identified specimen of $A$. cadurciella was found. In many other museums the specimens are either mixed with $A$. adspersella or with A. thapsiella or even with both (e.g. in NHMUK). So the misinterpretation of $A$. cadurciella as A. adspersella by RYMARCZYK et al. (2013) is understandable.

The specimens of $A$. adspersella, stored in NHMW and collected in its type area south of Vienna, clearly contradict the opinion of RYMARCZYK et al. (2013). There is an evidence for $A$. adspersella and A. cadurciella not being conspecific. In and around the type locality of $A$. adspersella there has never been found even a single specimen of $A$. cadurciella. The first author, who lives in this area and knows the microlepidoptera fauna very well, has never seen it there. Kollar described this species in 1832, so it is certainly possible that in nearly 200 years the fauna could have changed. Therefore, specimens of $A$. cadurciella were looked for in museum collections collected in Austria in the $19^{\text {th }}$ century. But although the majority of the large collections in Europe have been checked, no specimen of this species, collected in or near the type locality of $A$. adspersella or indeed anywhere in Austria could be found. On the other hand, the species with larva depicted as Fig. 142, reared from Bupleurum falcatum and corresponding in the black first pair of thoracic legs with A. feruliphila, is common in this area. This makes it most likely that Kollar, when describing $A$. adspersella, had in front of him specimens conspecific with the species which was described in 1866 by Millière as $A$. feruliphila, but not with the species which was described in 1914 by Chrétien as $A$. cadurciella.

In conclusion: $A$. feruliphila again becomes a synonym, but actually of $A$. adspersella, and not of $A$. thapsiella as was mentioned so far. This does not affect the specific difference between $A$. adspersella $(=$ A. feruliphila) and A. thapsiella, published by RYMARCZYK et al (2013) on the basis of differences in larval features. 


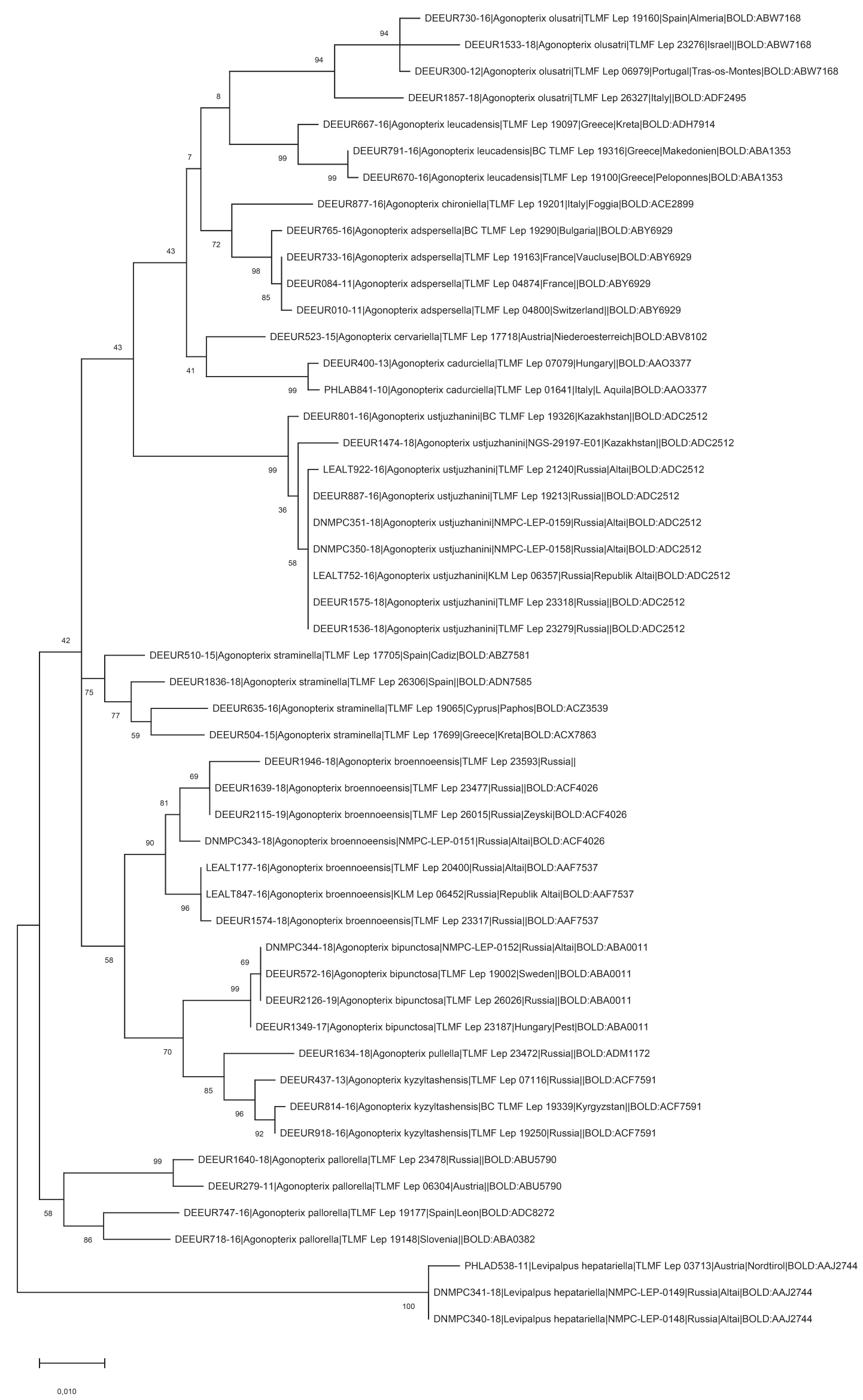

Fig. 146. Maximum likelihood tree of species from the Agonopterix adspersella group and the A. pallorella group with Levipalpus hepatariella (Lienig $\&$ Zeller, 1846) as an outgroup species (data from BOLD). 


\section{Checklist of taxa from the Agonopterix adspersella group}

Agonopterix adspersella (Kollar, 1832) (Haemylis); TL: Austria (near Vienna)

= amanthicella Heinemann, 1870 (Depressaria); TL: Europe (south)

= athamanticella Steudel \& Hofman, 1882 (?Agonopterix) (mis-spelling)

= sabulatella Turati, 1921 (Depressaria); TL: Italy (Rome: Monte Autore)

= karmeliella Amsel, 1935 (Depressaria); TL: "Palestine"

= rubripunctella Amsel, 1935 (Depressaria); TL: "Palestine"

= feruliphila Millière, 1866 (Depressaria) syn. nov.; TL: France

Agonopterix cadurciella (Chrétien, 1914) (Depressaria);

TL: France (Midi-Pyrénées: Causse de Gramat)

Agonopterix cervariella (Constant, 1884) (Depressaria);

TL: France (central)

Agonopterix chironiella (Constant, 1893) (Depressaria);

TL: France (Alpes Maritimes)

Agonopterix leucadensis (Rebel, 1932) (Depressaria);

TL: Greece

Agonopterix olusatri Corley \& Buchner, 2019; TL: Portugal

$=$ chironiella auct., nec. Constant (Agonopterix)

Agonopterix thapsiella (Zeller, 1847) (Depressaria); TL: Sicily

= linolotella Chrétien, 1929 (?Agonopterix); TL: France

In some internet sources Depressaria reichlini Heinemann, 1870 is erroneously listed as a synonym of $A$. adspersella, but it actually belongs to $D$. pimpinellae Zeller, 1839.

\section{Depressaria absynthiella Herrich-Schäffer, 1865}

Material examined. RUSSIA: Altai RepUblic: $45 \mathrm{~km} \mathrm{~N}$ of Ulagan vill., Chulyshman valley, $51^{\circ} 01^{\prime} 03^{\prime \prime} \mathrm{N}, 88^{\circ} 00^{\prime} 39^{\prime \prime} \mathrm{E}$, grassy steppe, rocks, 600 m, 27.-28.vi.2015, 4 \ठ 2 우우 (gen. prep. DEEUR 6170 P. Buchner), (Barcode TLMF Lep 23281), J. Šumpich leg. (NMPC).

Molecular data. BIN BOLD: ABA0596 $(\mathrm{n}=4,4$ public, 0 from Altai); BIN BOLD: ADM3466 $(\mathrm{n}=1,1$ public, 1 from Altai). The average intraspecific divergence of the barcode region between these clusters is $4.11 \%( \pm 1.15 \%)$ whereas only $0.48 \%$ (maximum $0.76 \%$ ) in the cluster with central-European specimens (BIN BOLD: ABA0596).

Distribution. From France to the Far East of Russia, but very scattered. Recorded also in the Canary Islands. In Russia very locally in south Siberia and Primorsky krai (Lvovsky 2006, 2008).

\section{Depressaria artemisiae Nickerl, 1864}

Material examined. RUSSIA: Altai Republic: Ust-Kan env. (6 km E), $50^{\circ} 56^{\prime} 05^{\prime \prime} \mathrm{N}, 84^{\circ} 51^{\prime} 17^{\prime \prime} \mathrm{E}$, grassy steppe, meadows, $1100 \mathrm{~m}$, 12.vii.2014, $1 \hat{\jmath}$ (Barcode NMPC-LEP-0168), J. Šumpich leg. (NMPC); Belyashi (Dzhazator) env. (25 km NW), confluence of Argut and Karagem rivers, $49^{\circ} 51^{\prime} 56^{\prime \prime} \mathrm{N}, 87^{\circ} 10^{\prime} 22^{\prime \prime} \mathrm{E}$, rocky steppe, $1400 \mathrm{~m}, 27 .-28 . v i i .2017,1$ ठ (Barcode NMPC-LEP-0295), J. Šumpich leg. (NMPC).

Molecular data. BIN BOLD: AAF8250 ( $\mathrm{n}=29,22$ public, 4 from Altai). The average intraspecific divergence of the barcode region is $0.90 \%$ (maximum $2.10 \%$ ). Two distinct clusters are developed, one of them comprises the Nearctic specimens and second one the Palaearctic ones where the Altaic specimens are assigned.

Distribution. Holarctic. In Russia widely distributed but local (Lvovsky 2006, 2008).

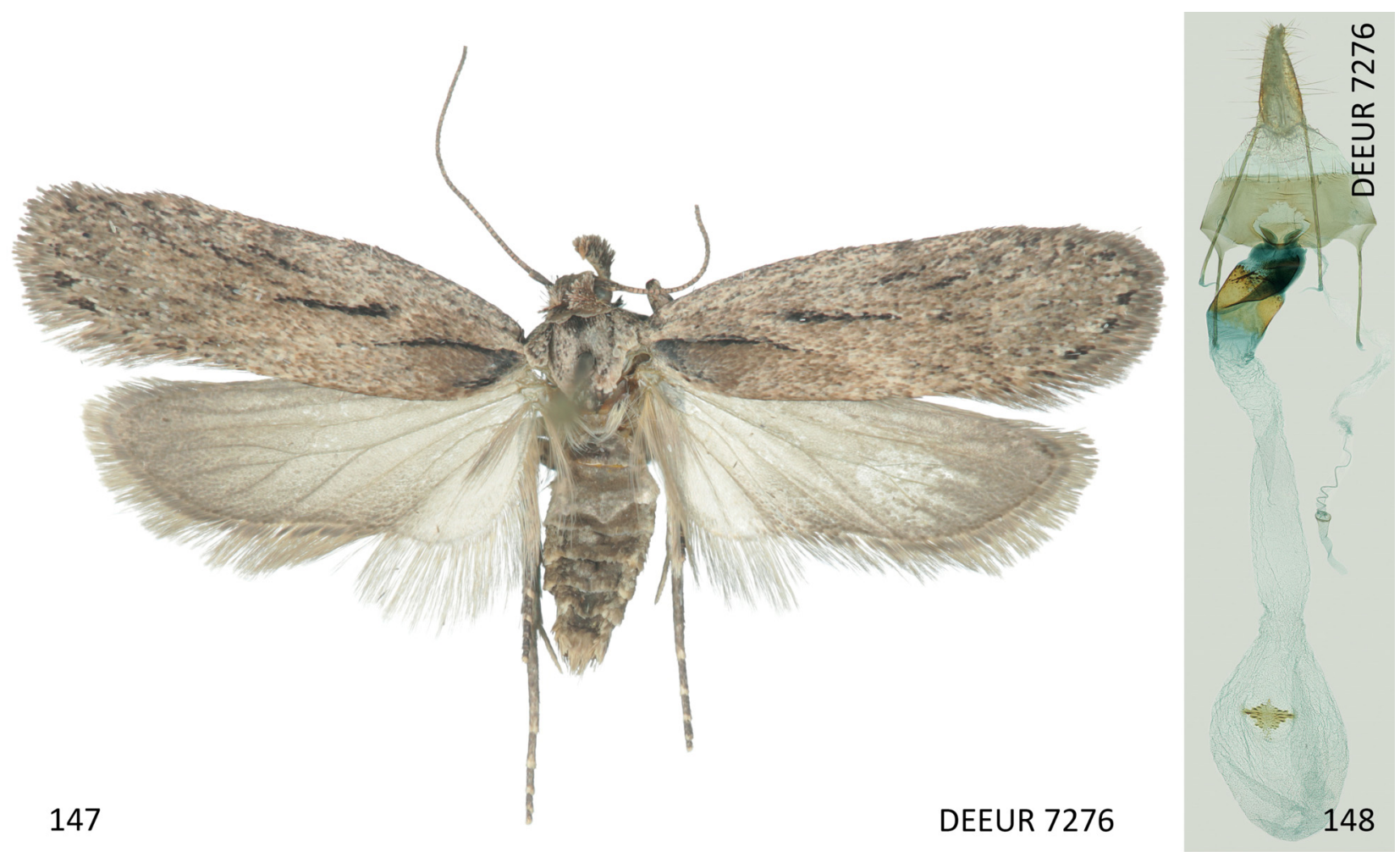

Figs 147-148. Depressaria atrostrigella Clarke, 1941, Russia, Altai Republic, Chulyshman valley, 27.-28.vi.2015, J. Šumpich leg. (NMPC): 147 habitus; 148 - female genitalia. 


\section{Depressaria atrostrigella Clarke, 1941 \\ (Figs 147-148)}

Material examined. RUSSIA: Altai RePUblic: Chulyshman valley, 45 $\mathrm{km} \mathrm{N}$ of Ulagan vill., $51^{\circ} 01^{\prime} 03^{\prime \prime} \mathrm{N}, 88^{\circ} 00^{\prime} 39^{\prime \prime} \mathrm{E}$, grassy steppe, rocks, 600 m, 27.-28.vi.2015, 2 우 (gen. prep. DEEUR 7276 P. Buchner, Barcode TLMF Lep 26020, gen. prep. DEEUR 7743), J. Šumpich leg. (NMPC).

Molecular data. BIN BOLD: ACR9498 $(n=5,3$ public, 2 from Altai). The average intraspecific divergence of the barcode region is $0.56 \%$ (maximum $0.81 \%$ ).

Distribution. Canada, U.S.A., Mongolia, Tajikistan, Russia. In Russia very locally in south Siberia (LvOvsKY 2006).

\section{Depressaria depressana (Fabricius, 1775)}

Material examined. RUSSiA: Altai Republic: Aktash vill., $50^{\circ} 19^{\prime} 12^{\prime \prime} \mathrm{N}, 87^{\circ} 36^{\prime} 00^{\prime \prime} \mathrm{E}$, grassy steppe, rocks, $1400 \mathrm{~m}, 21 . v i .2015,2$ 우, J. Šumpich leg. (NMPC); Kosh-Agach Distr., Chagan-Uzun env., Krasnaya Gorka hill, $50^{\circ} 05^{\prime} 00^{\prime \prime} \mathrm{N}, 88^{\circ} 25^{\prime} 15^{\prime \prime} \mathrm{E}$, rocky steppe, $1870 \mathrm{~m}$, 29.vi.2015, 2 우, DEEUR 7746 and 7747, J. Šumpich leg. (NMPC); Ust-Kan env. (6 km E), $50^{\circ} 56^{\prime} 05^{\prime \prime} \mathrm{N}, 84^{\circ} 51^{\prime} 17^{\prime \prime} \mathrm{E}$, grassy steppe, meadows, 1100 m, 12.vii.2014, 1 ภิ J. Šumpich leg. (NMPC); Shebalino Distr., Cherga vill. ( $8 \mathrm{~km} \mathrm{~W}), 51^{\circ} 34^{\prime} 04^{\prime \prime} \mathrm{N}, 85^{\circ} 28^{\prime} 33^{\prime \prime} \mathrm{E}$, rocky slopes, steppe,

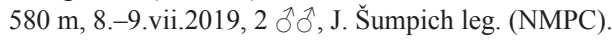

Molecular data. BIN BOLD: AAE7397 $(n=60,50$ public, 1 from Altai). The average intraspecific divergence of the barcode region is $0.14 \%$ (maximum $0.83 \%$ ). Distribution. Holarctic. In Russia widely distributed (Lvovsky 2006, 2008).

\section{Depressaria falkovitshi Lvovsky, 1990 (Figs 149-152)}

Material examined. RUSSIA: ALTAI REPUBLIC: Shebalino Distr., Cherga vill. (8 km W), $51^{\circ} 34^{\prime} 04^{\prime \prime} \mathrm{N}, 85^{\circ} 28^{\prime} 33^{\prime \prime} \mathrm{E}$, rocky slopes, steppe, $580 \mathrm{~m}$, 8.-9.vii.2019, 33 o 1 \%, J. Šumpich leg. (NMPC). Altai Region: Krasnostchekovo, Tigirek village, 10.vii.2014, 1 ð (DEEUR 6579, Barcode TLMF Lep 23510), S. Sinev leg. (ZIN).

Molecular data. BIN BOLD: ADM2807 ( $\mathrm{n}=3,0$ public, 1 from Altai) No intraspecific divergence of the barcode region was found. The closest related species is $D$. depressana (p-distance 5.2\%).

Distribution. Russia (from the Altai to the Far East), Kazakhstan (Lvovsky 2006). The first published records for the Altai Republic.

\section{Depressaria fuscovirgatella Hannemann, 1967 (Figs 153-156)}

Material examined. RUSSIA: Altai Republic: Chulyshman valley, $45 \mathrm{~km} \mathrm{~N}$ of Ulagan vill., $51^{\circ} 01^{\prime} 03^{\prime \prime} \mathrm{N}, 88^{\circ} 00^{\prime} 39^{\prime \prime} \mathrm{E}$, grassy steppe, rocks,
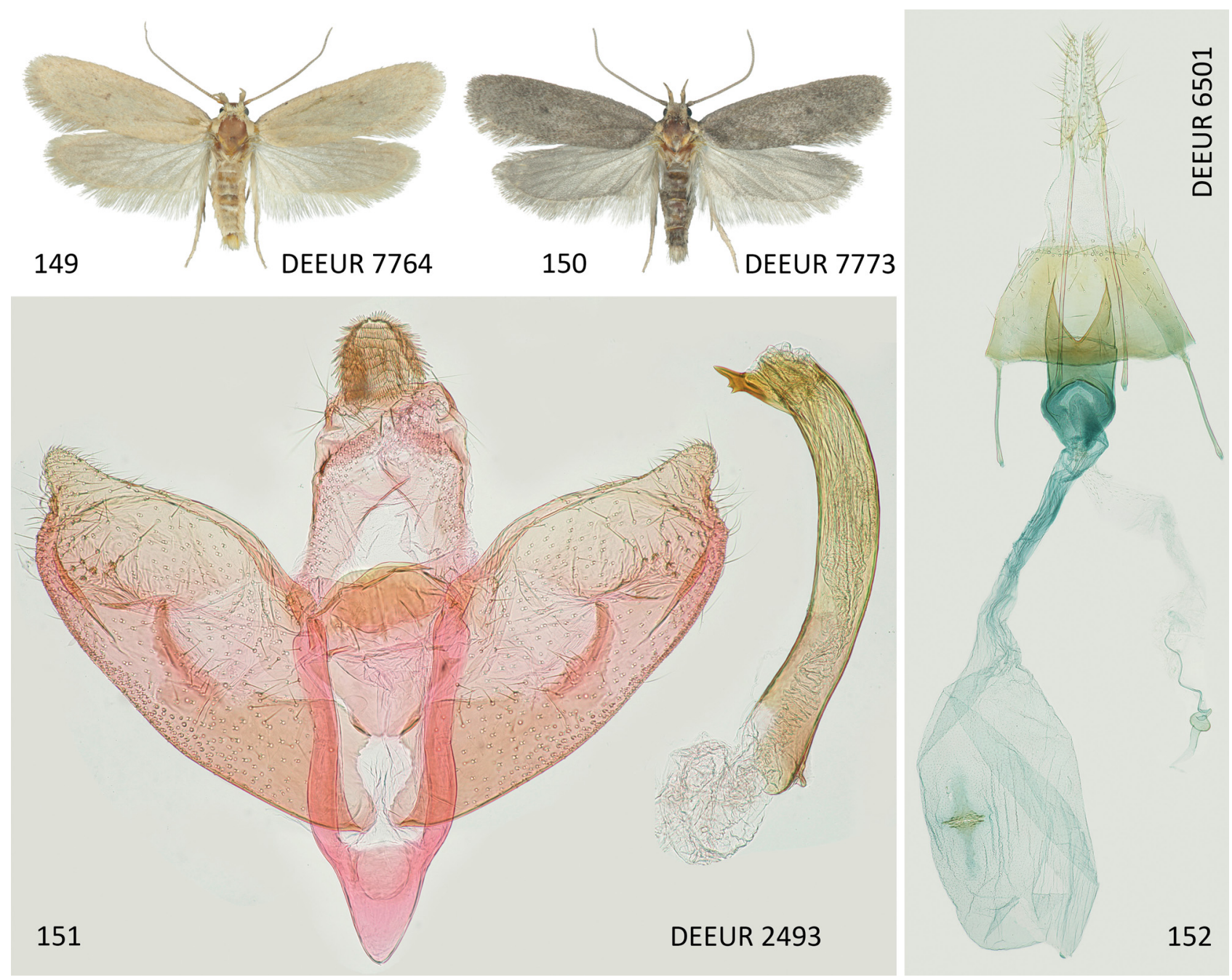

Figs 149-152. Depressaria falkovitshi Lvovsky, 1990. 149-150 - habitus, Russia, Altai Mts., Cherga (details in the text); 151 - male genitalia, Mongolia, Changai, without date, ex coll. C.S.Larsen (ZMUC); 152 - female genitalia, Russia, Buryatia, Barguzin valley, 3.vii.1996, Jalava \& Kullberg leg. (ZMUH). 

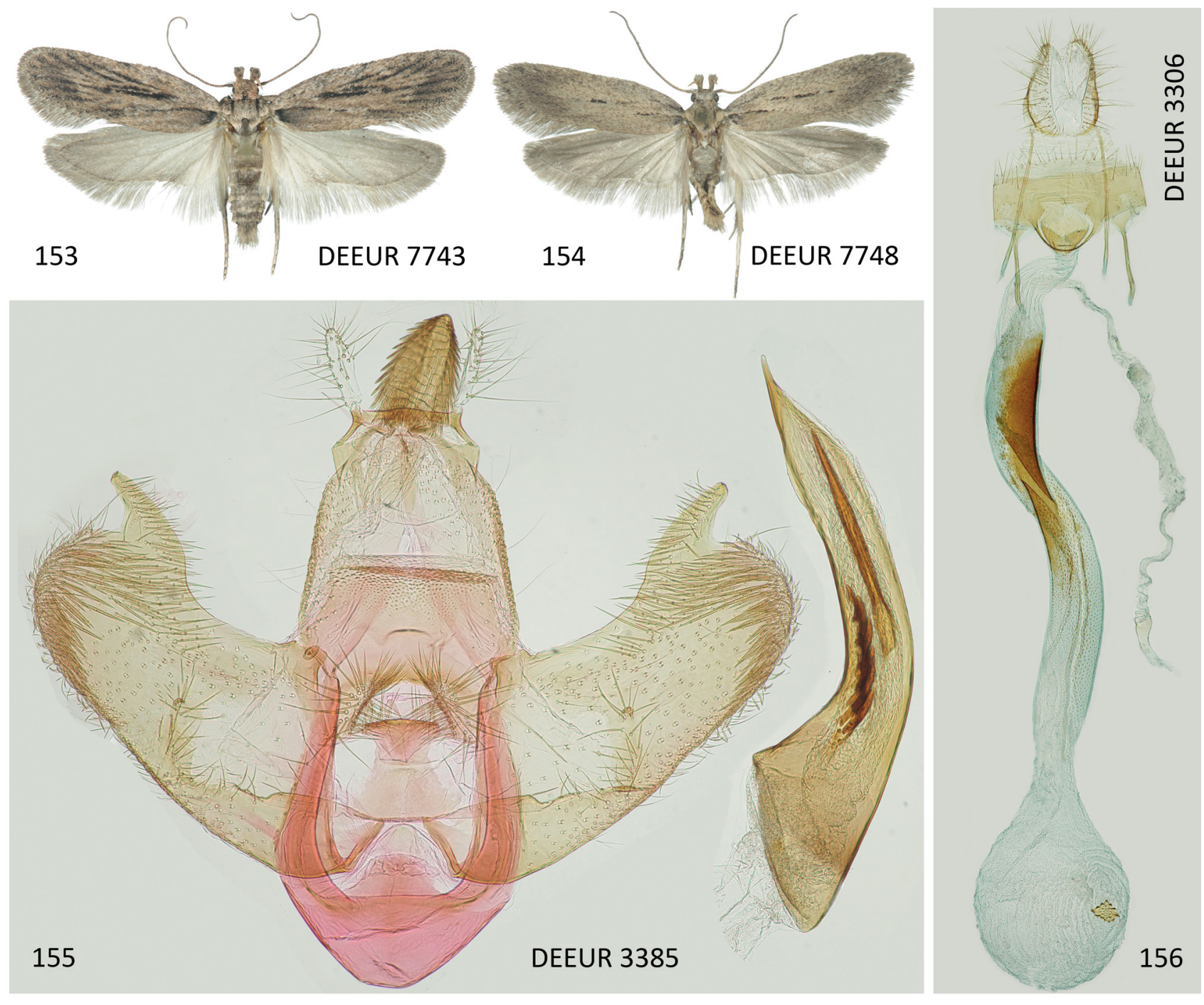

Figs 153-156. Depressaria fuscovirgatella Hannemann, 1967. 153-154 - habitus, Russia, Altai Mts. (details in the text); 155 - male genitalia, Turkey, Erzurum, Kop geçidi, 25.vii.1993, K. Larsen leg. (RCKL); 156 - female genitalia, Turkey, Sivas, Gökpinar, 1.viii.1997, K. Larsen leg. (RCKL).

600 m, 26.vi.-5.vii.2019, 3 के ô (gen. prep. DEEUR 7748 P. Buchner), J. Šumpich leg. (NMPC).

Molecular data. BIN BOLD: ACS6435 and ADC1617 ( $\mathrm{n}=6,2$ public, 1 from Altai). Sequences split into two clusters, maximum intraspecific divergence of the barcode region is $6.08 \%$.

Distribution. Russia, Kazakhstan, Armenia, Turkmenistan, Iran, Afghanistan, Mongolia (Lvovsky 2006), and Turkey (BuCHNER 2017). The first records for the Altai Republic.

\section{Depressaria libanotidella Schläger, 1848 \\ (Figs 157-165)}

Material examined. RUSSIA: Altai Republic: Kosh-Agach Distr.,

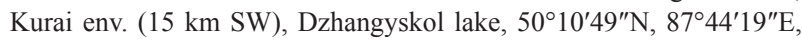
coniferous forest/steppe, $1830 \mathrm{~m}, 24 .-25 . v i .2015,1$ \& (gen. prep. DEEUR 7672 P. Buchner), (Barcode NMPC-LEP-0161), J. Šumpich leg. (NMPC); $45 \mathrm{~km}$ N of Ulagan vill., Chulyshman valley, $51^{\circ} 01^{\prime} 03^{\prime \prime} \mathrm{N}, 88^{\circ} 00^{\prime} 39^{\prime \prime} \mathrm{E}$, grassy steppe, rocks, $600 \mathrm{~m}, 27 .-28 . v i .2015,1$ ㅇ (gen. prep. DEEUR 7665 P. Buchner), (Barcode NMPC-LEP-0162), J. Šumpich leg. (NMPC).

Molecular data. BIN BOLD: ADR8049 $(\mathrm{n}=2,2$ public, 2 from Altai, with divergence of $0.16 \%$ ). The nearest neighbour with $1.83 \%$ p-distance is D. libanotidella from
Europe in a cluster with BIN BOLD AAF8171 ( $\mathrm{n}=17)$. Depressaria libanotidella $(\mathrm{n}=2)$ is also present in a separated cluster with BIN BOLD ABY4795, together with D. bantiella (Rocci, 1934) $(\mathrm{n}=4)$, D. platytaeniella Hannemann, $1977(\mathrm{n}=3)$, D. velox Staudinger, $1859(\mathrm{n}=9)$, and 1 with genitalia closest to D. bantiella, but without final determination. Distance of BIN BOLD ADR8049 to ABY4795 is $3.36 \%$, AAF8171 to ABY4795 3.29\%. The barcode situation is reminiscent of that in the Agonopterix putridella group.

\section{Depressaria paraleucocephala sp. nov.} (Figs 166-173, 180)

Type material. Holotype: $\widehat{\partial}$ (NMPC), Russia: Altai Republic: Chulyshman valley, $45 \mathrm{~km} \mathrm{~N}$ of Ulagan vill., $51^{\circ} 01^{\prime} 03^{\prime \prime} \mathrm{N} ; 88^{\circ} 00^{\prime} 39^{\prime \prime} \mathrm{E}$, grassy steppe, rocks, 600 m, 27.-28.vi.2015 (Barcode TLMF Lep 23280), Jan Sumpich leg. PARATYPES: 10 ô 7 우 9 (NMPC): the same data as holotype

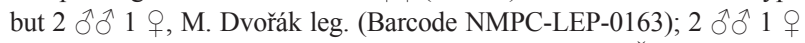
(NMPC), the same data as holotype but 26.-27.vi.2019, J. Šumpich leg.; 1 $\widehat{I}$ (NMPC), the same data as holotype but 4.-5.vii.2019, J. Šumpich leg.; Belyashi (Dzhazator) env. (25 km NW), confluence of Argut and Karagem rivers, $49^{\circ} 51^{\prime} 56^{\prime \prime} \mathrm{N}, 87^{\circ} 10^{\prime} 22^{\prime \prime} \mathrm{E}$, rocky steppe, $1400 \mathrm{~m}, 27$.-28.vii.2017, 1 + (Barcode NMPC-LEP-0164), J. Šumpich leg. (NMPC). 

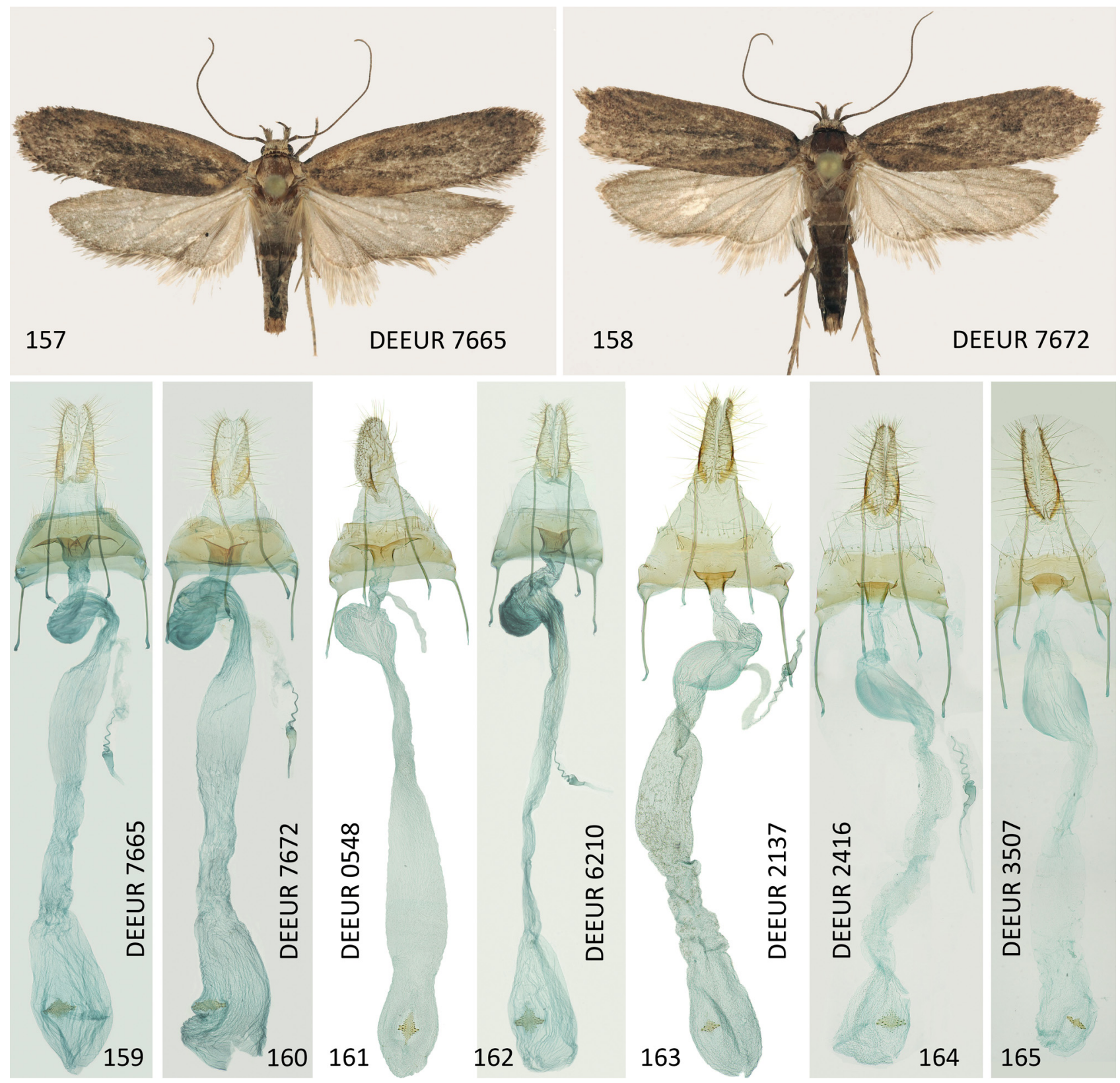

Figs 157-165. Depressaria libanotidella group. 157-162 - Depressaria libanotidella Schläger, 1848: 157-158 - habitus, Russia, Altai Mts. (details in the text): 157 - Chulyshman; 158 - Dzhangyskol; 159-162 - female genitalia: 159 - data as fig. 157; 160 - data as fig. 158; 161 - Switzerland, Jura, Soulce, 1.ix.2008, e.1. Seseli libanotis, P. Sonderegger leg. (NMBE); 162 - Italy, Ortler, Passo di Stelvio, 18.-19.vi.2004, J. Skyva leg. (NMPC). $163-164$ - D. bantiella (Rocci, 1934): 163 - Montenegro, Humsko Blato, 15.vii.-5.viii.2014, e.1. Apiaceae sp., F. Graf leg. (RCFG); 164 - Greece, Troodos Mts., Olympus, 23.-28.vi.1997, D. Nilsson, A. Madsen, M. Fibiger \& P. Svendsen leg. (ZMUC). 165 - D. velox Staudinger, 1859, Bulgaria, Slavyanka Mts. Livade, 15.vi.2010, B. Zlatkov \& O. Sivilov leg. (RCBZ).

Description. Adult (Figs 166-172). Wingspan 20-25 mm. Head with raised whitish to pale yellowish scales on neck and crown, mixed with medium brown or medium reddish scales in different proportions; face of the same colours. Labial palp segment 3 with $3 / 5$ length of segment 2; segment 2 with broad scales, protruding on ventral and adpressed on lateral and dorsal sides, outer side with dark brown scales at base and with mix of whitish, reddish and medium brown scales on upper part, forming distinct contrast on outer side at $1 / 3$ to $1 / 2$, inner side whitish, ventral side medium brown; segment 3 slender with adpressed, medium brown to reddish brown scales, blackish ring in distal half, not reaching tip (Figs 170-172). Antenna dark brown. Colour of thorax similar to head, but with darker median line, especially in anterior half, in general forming distinct contrast against dark brown tegulae and forewings. Forewing dark brown or dark reddish brown, in some specimens less dark near costa, with about 7-8 black vein-associated streaks, more distinct in distal half, whitish scales scattered throughout forewing in low but variable number, in larger number at $1 / 3$ in some specimens, forming diffuse longitudinal streak; at $1 / 2$ distinct round white spot with diameter of about $0.5 \mathrm{~mm}$; angled transverse line with tip at about $4 / 5$, common feature in genus Depressaria, is present and fairly distinct, paler than ground colour; interneural dots blackish, distinct, in some specimens nearly confluent and forming interrupted dark 

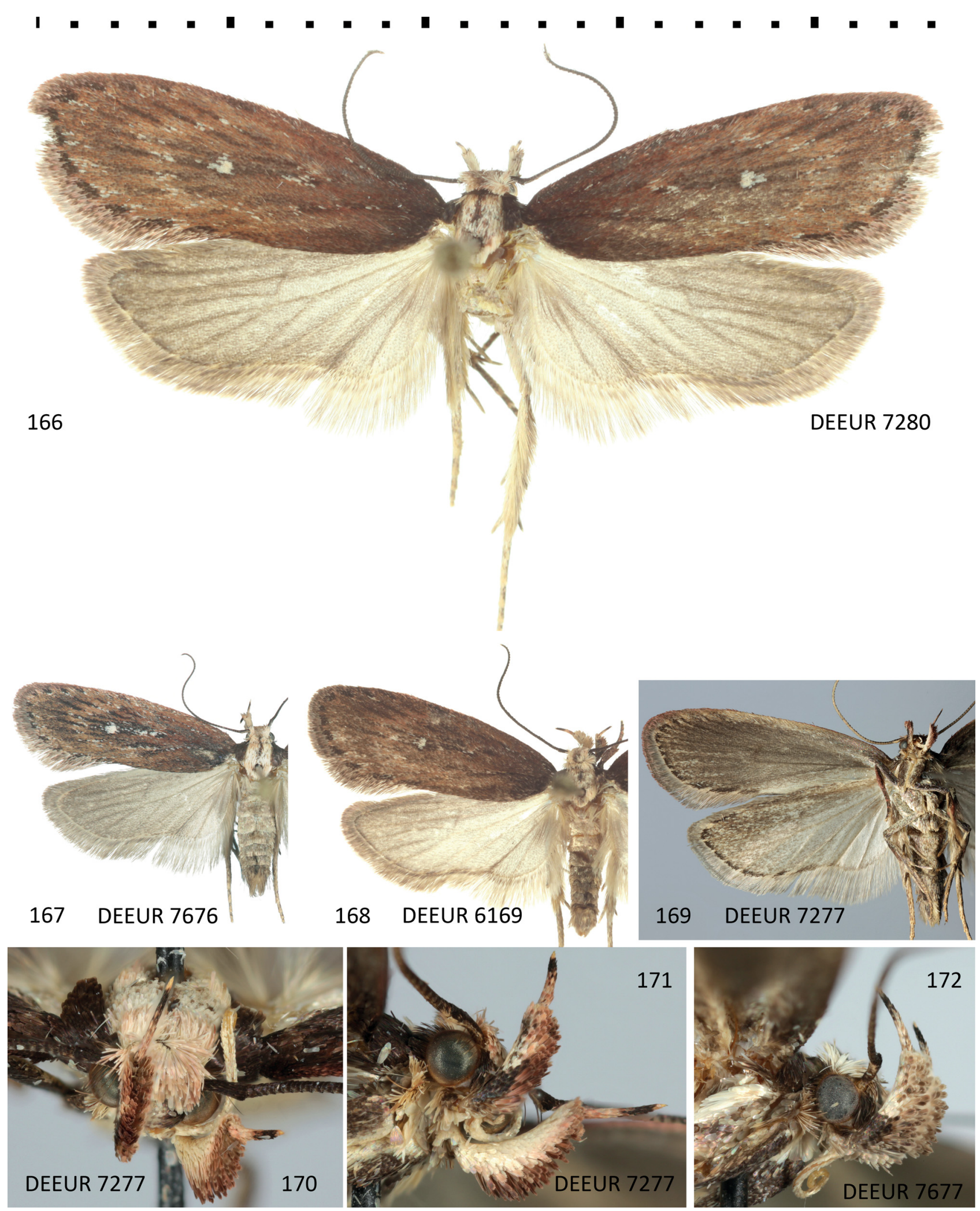

Figs 166-172. Depressaria paraleucocephala sp. nov. 166 - holotype; 167-172 - paratypes (Chulyshman): 167-168 - dorsal view; 169 - ventral view; 170-172 - head and labial palpi.

line; basal row of fringe scales dark brown, distal row paler, medium greyish brown; underside uniformly grey, only at costa paler and with nearly confluent dark interneural dots. Hindwing grey, becoming darker posteriorly, with narrow blackish line at fringe-base; fringe similar to ground colour, but with distinct darker band at basal 1/3; underside similar to upper side, only in distal 1/3 more mottled (Fig. 169). Legs without distinct patterns, predominantly dark grey, but tibia and tarsus of hindlegs paler, with mix of brown and yellowish brown scales. Abdomen without patterns, predominantly light grey on upper side and dark grey on underside.

No sex associated differences could be found. 


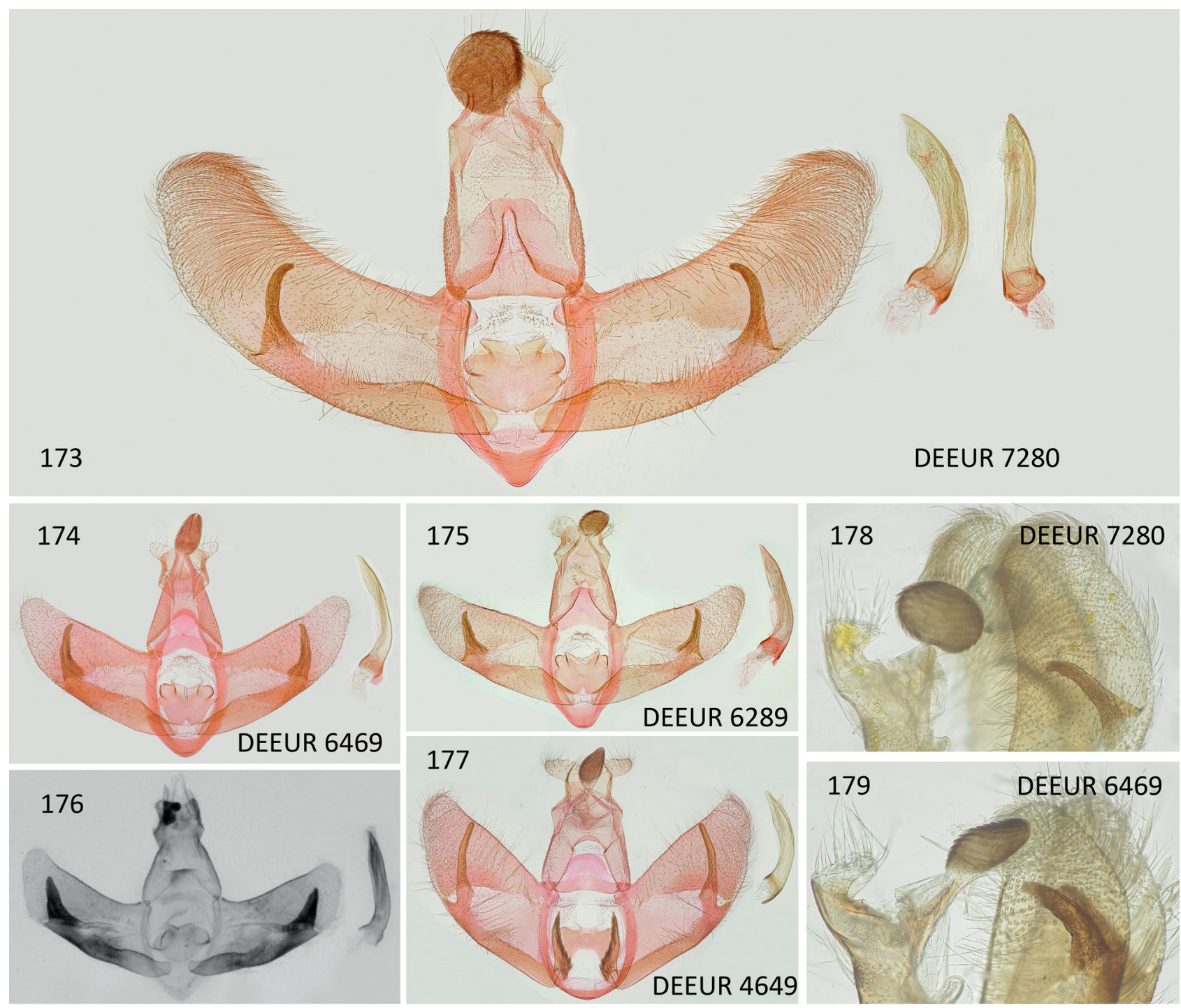

Figs 173-179. Male genitalia of Depressaria paraleucocephala sp. nov. and related taxa. 173 - D. paraleucocephala, holotype. 174-175 - D. leucocephala Snellen, 1884: 174 - Russia, Orenburg Oblast, Donskoe, 6 km W Mt. Verbljushka, 17.viii.2006, K. Nupponen leg. (RCKN); 175 - Russia, Primorsky Krai, Ussuri, Kazakevich, without further data (MGAB). 176 - D. alienella Busck, 1904, USA, Colorado, viii.1891, genitalia slide JFCG4753, without further data (NHMUK). 177 - D. emeritella Stainton, 1849, Kazakhstan, Emba, 10.x.2013, K. Nupponen leg. (RCKN). 178-179 - detail of gnathos in free floating position: $178-$ D. paraleucocephala sp. nov., holotype; $179-$ D. leucocephala, data as fig. 174.

Variation. Number of whitish scales and distinctness of forewing patterns vary to some extent as shown by examples in Fig. 167 for rich and in Fig. 168 for poor contrast.

Male genitalia (Figs 173, 178). Uncompressed gnathos broad elliptic in lateral view (Fig. 178), $0.5 \mathrm{~mm}$ long and $0.7 \mathrm{~mm}$ wide (may appear globose in standard preparation), socii triangular, length of each about half of longest gnathos diameter. Tegumen slightly tapering from $1.1 \mathrm{~mm}$ width at base to $0.9 \mathrm{~mm}$ before bulging at posterior end, length $1.4 \mathrm{~mm}$. Valva about $3.0 \mathrm{~mm}$ long and $1.0 \mathrm{~mm}$ wide, evenly curved and almost parallel-sided up to rounded end. Clavus absent, sacculus broadest at about $1 / 10$ from valva base with about $1 / 3$ of valva width, from here gradually tapering, ending at $3 / 5$ of valva length in stout cuiller, which is covered with short adpressed spinulae and directed towards costa, bent inwards slightly at base and ending in more strongly bent tip at about $4 / 5$ of valva width. Anellus broad elliptic, evenly rounded at anterior margin, posterior margin with pair of triangular processes diverging about $120^{\circ}$, lateral margin with semicircular bulge just anterior to triangular process on either side. Transtilla with transverse length of about $1.0 \mathrm{~mm}$, gradually expanding towards middle where it reaches width of about $0.3 \mathrm{~mm}$. Aedeagus rather stout, $1.5 \mathrm{~mm}$ long and $0.20-0.25 \mathrm{~mm}$ wide, almost parallel-sided except for slightly swollen base and oblique tip, evenly curved in lateral view with bend of about $80^{\circ}$ from base to tip on convex side, at this side basal part with $0.1 \mathrm{~mm}$ long, narrow triangular process, cornuti absent.

Female genitalia (Fig. 180). Papilla analis about 1.2 $\mathrm{mm}$ long, elliptical in lateral view with maximum width of $0.75 \mathrm{~mm}$, posterior apophysis $1.6 \mathrm{~mm}$ long. Length of sternite VIII $1.1 \mathrm{~mm}$ laterally and $0.6 \mathrm{~mm}$ centrally, maximum width $2.0 \mathrm{~mm}$ in standard preparation, anterior apophysis $0.6 \mathrm{~mm}$ long; proximal edge of sternite VIII 


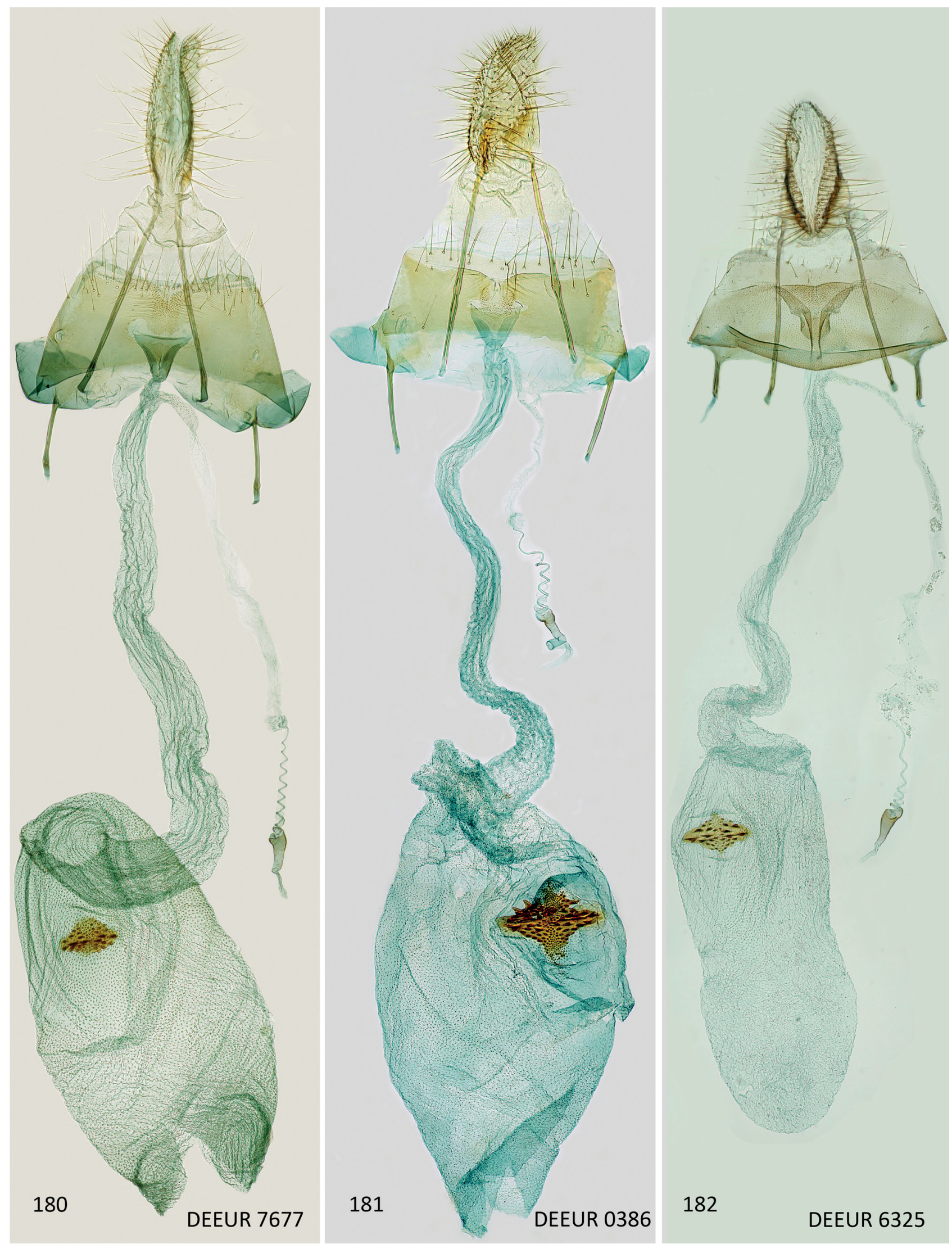

Figs 180-182. Female genitalia of Depressaria paraleucocephala sp. nov. and related taxa. 180 - D. paraleucocephala, paratype (Chulyshman); $181-$ D. leucocephala Snellen, 1884, Italy, South Tyrol, Laas, end of vi.1977, e.1. Artemisia vulgaris, K. Burmann leg. (TLMF); 182 - D. emeritella Stainton, 1849, Romania, Sarerdö Szatmar, 14.ix.1992, without further data (MGAB). 

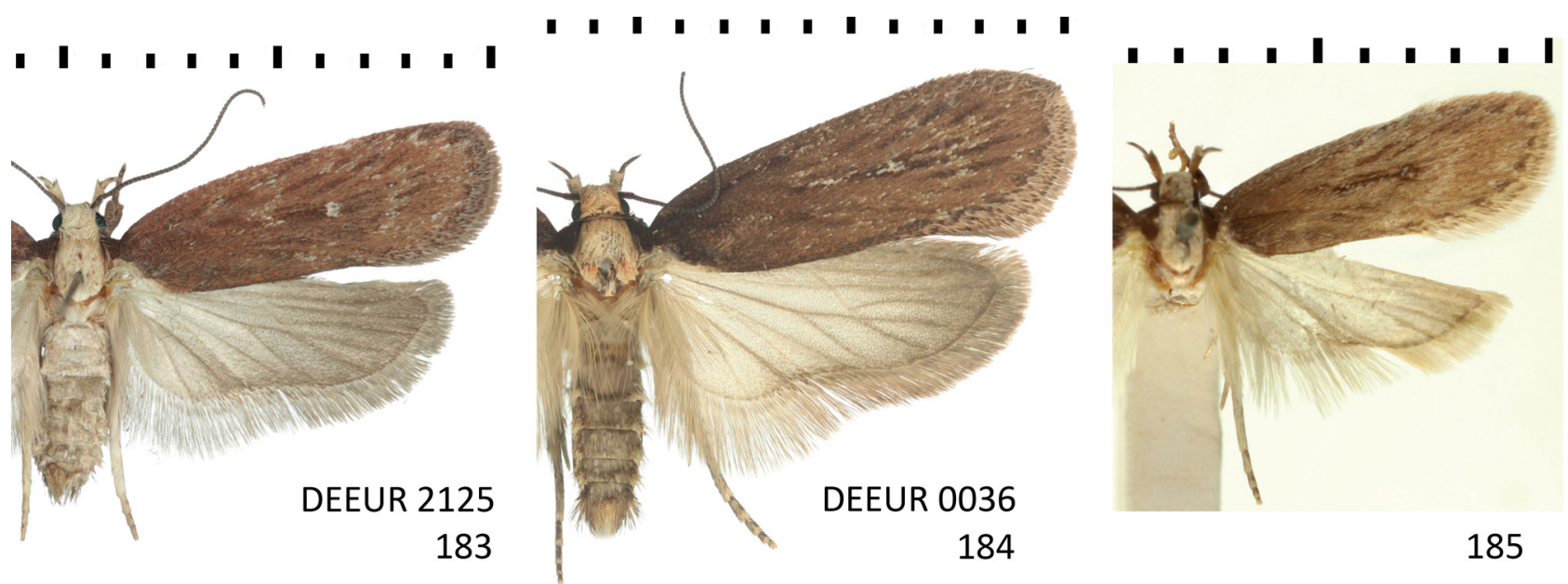

183
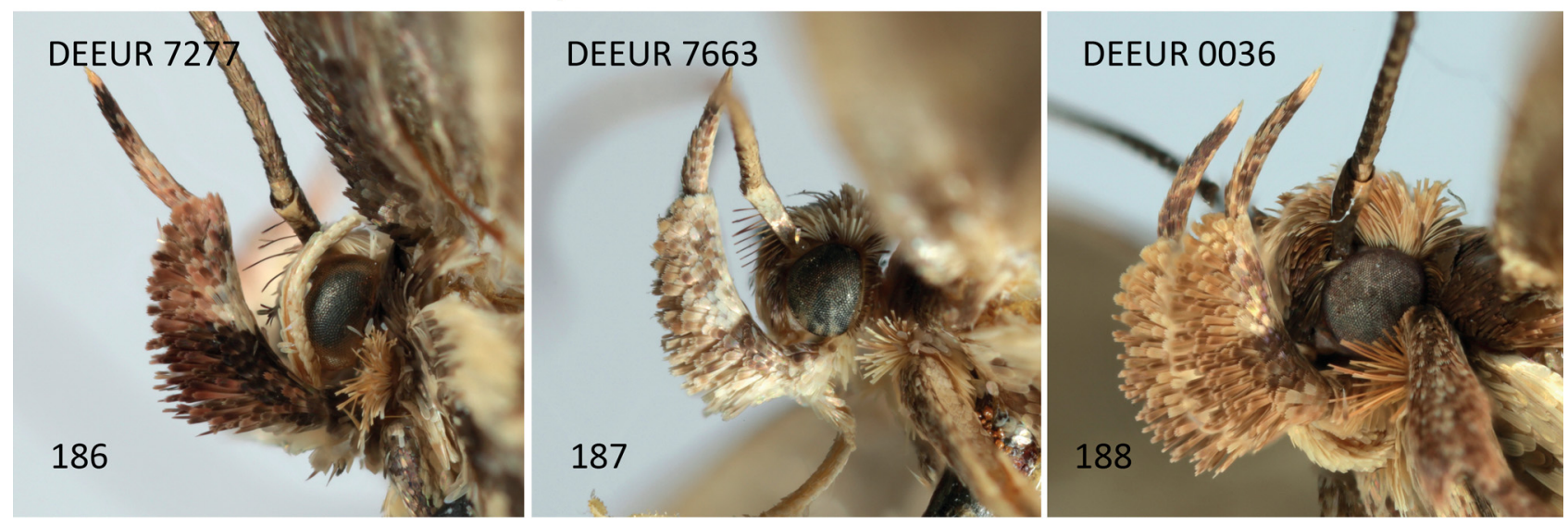

Figs 183-188. Habitus of Depressaria species related to D. paraleucocephala sp. nov. 183 - D. leucocephala Snellen, 1884, Italy. South Tyrol, Laas, end of vi.1976, e.1. Artemisia vulgaris, K. Burmann leg. (TLMF); 184 - D. emeritella Stainton, 1849, Austria, Schwarzau am Steinfeld, 9.vi.-16.vii.2009, e.1. Tanacetum vulgare, P. Buchner leg. (RCPB); 185 - D. alienella Busck, 1904, USA, Oregon, Josephine Co., Rouge River, vi.1872, e.1. Artemisia sp., NHMUK010891375, T. Walsingham leg. (NHMUK). 186-188 - detail of labial palpi: 186 - D. paraleucocephala sp. nov., paratype (Chulyshman); 187 - D. leucocephala, Russia, Primorsky krai, Slavyanki Ryasaiovka, 7.viii.1983, A. Lvovsky leg. (ZMHB); 188 - D. emeritella, data as fig. 184.

concave, ostium dumbbell-shaped, $0.6 \mathrm{~mm}$ wide, $0.25 \mathrm{~mm}$ long at sides but $0.1 \mathrm{~mm}$ long in centre, located in middle of sternite VIII. Between centre of ostium and posterior edge of sternite VIII small area covered with tiny spinulae. Antrum triangular, $0.4 \mathrm{~mm}$ wide and $0.3 \mathrm{~mm}$ long, exceeding anterior margin of sternite VIII. Segment VIII with intersegmental skin somewhat thickened antero-laterally, not forming lobes characteristic for e.g. D. douglasella Stainton, 1849, but reminiscent of this structure. Ductus bursae about $4 \mathrm{~mm}$ long, diameter $0.3 \mathrm{~mm}$ near antrum, slightly widening in its course to $0.5 \mathrm{~mm}$, with irregular, predominantly longitudinal folds throughout its whole length, predominantly straight throughout most of its course, but with semicircular loop before meeting corpus bursae. Corpus bursae with elliptic outline, about $3.0 \mathrm{~mm}$ long and $1.5 \mathrm{~mm}$ wide, signum at end of distal $1 / 3$, oval, $0.3 \mathrm{~mm}$ long and $0.4 \mathrm{~mm}$ wide, with numerous teeth of different sizes, largest along transverse axis; ductus spermathecae with about 8 turns.

Differential diagnosis. Very similar to D. leucocephala Snellen, 1884 (Fig. 183) and D. emeritella Stainton, 1849 (Fig. 184), which correspond in whitish to pale brownish thorax, contrasting against dark tegulae and forewings. Depressaria alienella Busck, 1904 (Fig. 185) also belongs to this group and we mention this North American species here because it is the nearest neighbour in the DNA-barcode. Externally the most distinct difference is the dark longitudinal stripe in the middle of thorax, not present in the compared species, and often also the larger and therefore much more prominent white central dot in $D$. paraleucocephala, but the latter feature may be indistinct in some specimens. Additionally, the dark area at base of the outer side of the second labial palp segment and the black ring of its third segment tend to be larger and clearer than in D. leucocephala. In D. emeritella, the dark colour on the inner side of the third labial segment tends to extend to its base, and $D$. alienella is distinctly smaller. In cases of doubt dissection of genitalia is necessary.

The species D. sibirella Lvovsky, 1981, D. spectrocentra Meyrick, 1935, and D. filipjevi Lvovsky, 1981, which are close in DNA-barcoding, are excluded from a detailed comparison here, because they do not have a pale thorax contrasting against dark tegulae and forewings, and in male genitalia these three species differ from $D$. paraleucocephala in the presence of a clavus.

In male genitalia, $D$. emeritella is very distinct by the presence of clavus, absence of semicircular bulges of anellus and much longer cuiller (Fig. 177). Genitalia of D. leucocephala (Figs 175, 179) are more similar, the differences are best compared in Table 3. Male genitalia 
Table 3. Comparison of Depressaria leucocephala Snellen, 1884 and D. paraleucocephala sp. nov. based on male genitalia.

\begin{tabular}{lll}
\hline Character & D. leucocephala & D. paraleucocephala \\
\hline gnathos & longer than broad & globose to slightly broader than long \\
\hline anellus & semicircular bulges directed obliquely upward & semicircular bulges directed sideways \\
\hline cuiller & $\begin{array}{l}\text { rather broad at base, tapering towards the tip, rather straight, } \\
\text { only bent inwards close to the tip }\end{array}$ & $\begin{array}{l}\text { rather broad at base, tapering in basal 1/3, then with about the } \\
\text { same width towards the tip, bent over all its length, although } \\
\text { more strongly towards the tip }\end{array}$ \\
\hline shape of valva & parallel-sided only in basal half, tapering in distal half & parallel-sided to the broadly rounded tip \\
\hline aedeagus & distinctly bent only in basal half in lateral view & equally bent over the whole length in lateral view \\
\hline
\end{tabular}

of $D$. alienella are similar to those of $D$. leucocephala, but cuiller is even shorter, straight and stouter, so this feature is sufficient to separate this species from $D$. paraleucocephala (in the slide gnathos may be damaged, cf. Fig. 176).

Female genitalia of D. paraleucocephala (Fig. 180) are most similar to those of $D$. leucocephala (Fig. 181), but differ in several details (comparison given in brackets): proximal edge of sternite VIII distinctly concave (vs. moderately concave), medio-ventral length $0.6 \mathrm{~mm}$ (vs. $0.4 \mathrm{~mm}$ ), ostium dumbbell-shaped (vs. not widened laterally), ductus spermathecae with about 8 turns (vs. 6 turns) and signum small, $0.3 \times 0.4 \mathrm{~mm}$ (vs. $0.6 \times 0.8 \mathrm{~mm}$ ).
Depressaria emeritella (Fig. 182) differs clearly in field of microtrichia much larger, nearly covering the whole sternite VIII and antrum opening in a wide funnel and reaching the caudal edge of sternite VIII.

Molecular data. BIN BOLD: ADM4194 ( $\mathrm{n}=3,3$ public, 3 from Altai). The average intraspecific divergence of the barcode region is $0.21 \%$ (maximum $0.32 \%$ ). The nearest neighbour is the North American species D. alienella with $3.38 \%$ p-distance, the nearest Palaearctic species is $D$. sibirella with $3.52 \%$ p-distance, followed by D. spectrocentra (4.13\%), D. filipjevi (4.25\%), and D. leucocephala $(4.29 \%)$.

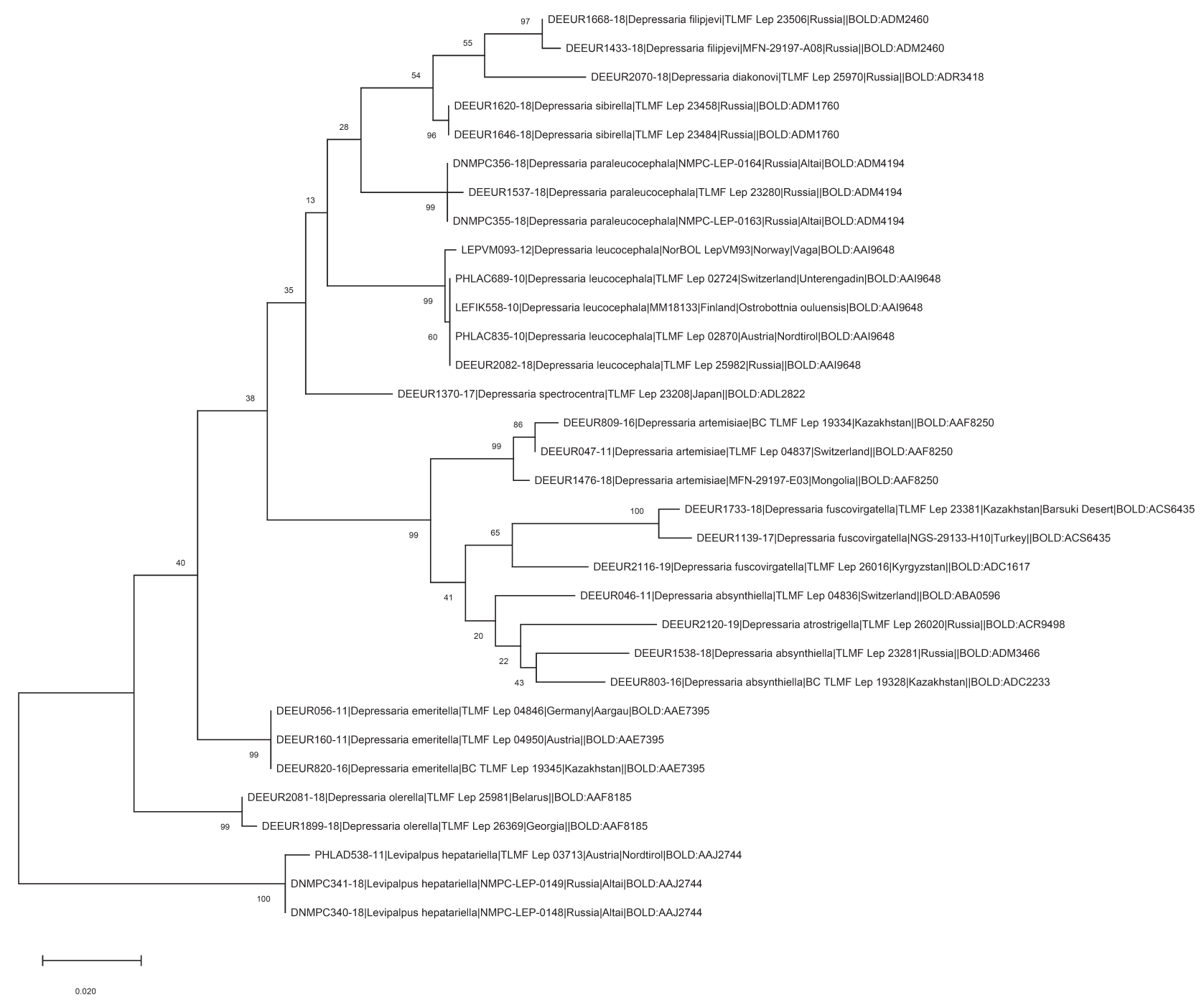

Fig. 189. Maximum likelihood tree of Depressaria paraleucocephala sp. nov. and related taxa with Levipalpus hepatariella (Lienig \& Zeller, 1846) as an outgroup species (data from BOLD). 
Etymology. The species name paraleucocephala recognises the high similarity with $D$. leucocephala; adjective. Biology. Unknown. The closest related species feed on Asteraceae (Artemisia L., Achillea L.) as far as known, so D. paraleucocephala can be expected to feed on Asteraceae too.

Distribution. Russia (the Altai Republic).

Remark. Because D. paraleucocephala can be easily confused with $D$. leucocephala we examined also some Russian material identified as D. leucocephala (incl. specimens from the Far East), but we can confirm their correct identification. At present it seems that $D$. paraleucocephala may be endemic to the Altai Mountains.

\section{Depressaria sibirella Lvovsky, 1981 (Figs 190-192)}

Material examined. RUSSiA: Altai Republic: Aktash vill., $50^{\circ} 19^{\prime} 12^{\prime \prime} \mathrm{N}, 87^{\circ} 36^{\prime} 00^{\prime \prime} \mathrm{E}$, grassy steppe, rocks, $1400 \mathrm{~m}, 21 . v i .2015,1 \mathrm{o}^{3}$ (Barcode NMPC-LEP-0167), J. Šumpich leg. (NMPC).

Molecular data. BIN BOLD: ADM1760 ( $\mathrm{n}=3,3$ public, 3 from Altai). No intraspecific divergence of the barcode region is presented.

Distribution. Russia (from Tyumen to Amur Region) (Lvovsky 1981, 2006, 2008). The first record for the Altai Republic.

\section{Comments on Depressaria altaica and $D$. schaidurovi}

\section{Depressaria altaica Zeller, 1854}

(Figs 193-198)

Type material examined. LECTOTYPE: $\precsim$ (ZMHB), KAZAKHSTAN: labeled "Altai", [A. Kindermann leg., ex. coll. J. Lederer].

Additional material examined. RUSSIA: ORENBURSKAYA OBLAST: Schibendy valley, $20 \mathrm{~km} \mathrm{~S}$ of Pokrovka, 1.v.2003, 1 (gen. prep. DEEUR 4603 P. Buchner), (Barcode KN00082), K. Nupponen leg. (RCKN); the same locality but 28.ix.2005, 1 oै (gen. prep. DEEUR 6465 P. Buchner), (Barcode TLMF-Lep-26340 [failed]), K. Nupponen leg. (RCKN).

Molecular data. Only one successfully barcoded specimen of $D$. altaica is stored in the BOLD (sample ID KN00082) (Figs 195-196) but we do not have access to its complete data or its BIN. However, the owner of this record, Kari Nupponen, has provided us with the sequence for comparison with related taxa, and as a result, $8.9 \%$ p-distance between $D$. altaica and D. schaidurovi can be presented.

Distribution. Kazakhstan (Altai) (ZELLER 1854, LEDERER 1855), Tajikistan (Lvovsky 1981), Russia (South Ural). New species for Russia.

Remark. Philipp Christoph Zeller described D. altaica based on material collected by Albert Kindermann in Western Altai (SE Kazakhstan) during his expedition along the Irtysh River between Ust-Kamenogorsk and
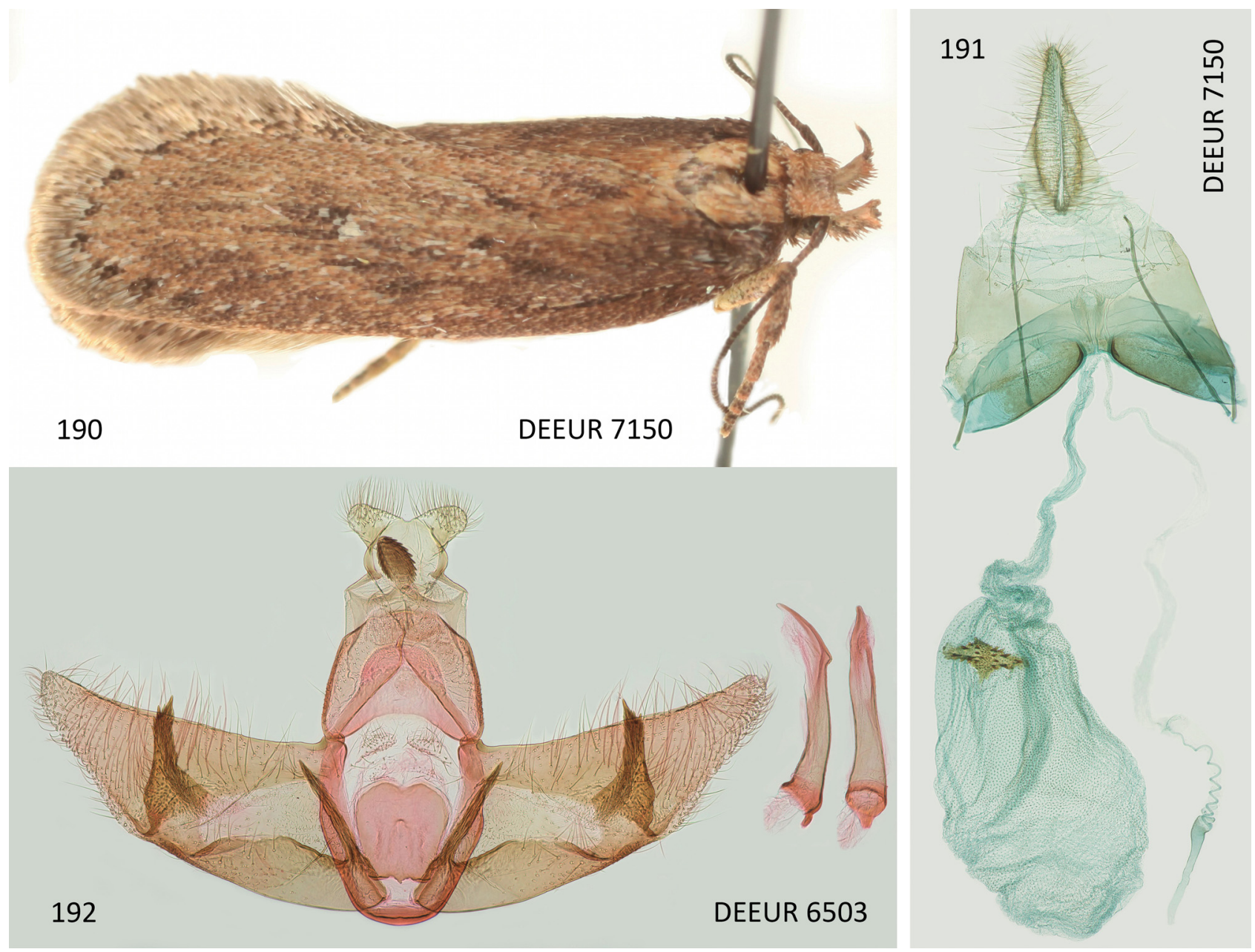

Figs 190-192. Depressaria sibirella Lvovsky, 1981. 190 - habitus, Russia, Altai Mts., Ongudaiski, Talda, 6.viii.2000, A. Bidzilya leg. (ZIN); 191 - female genitalia, data as fig. 190; 192 - male genitalia, Russia, Buryatia, 35 km SW Ulan Ude, 26.iv.1998, Kullberg leg. (ZMUH). 

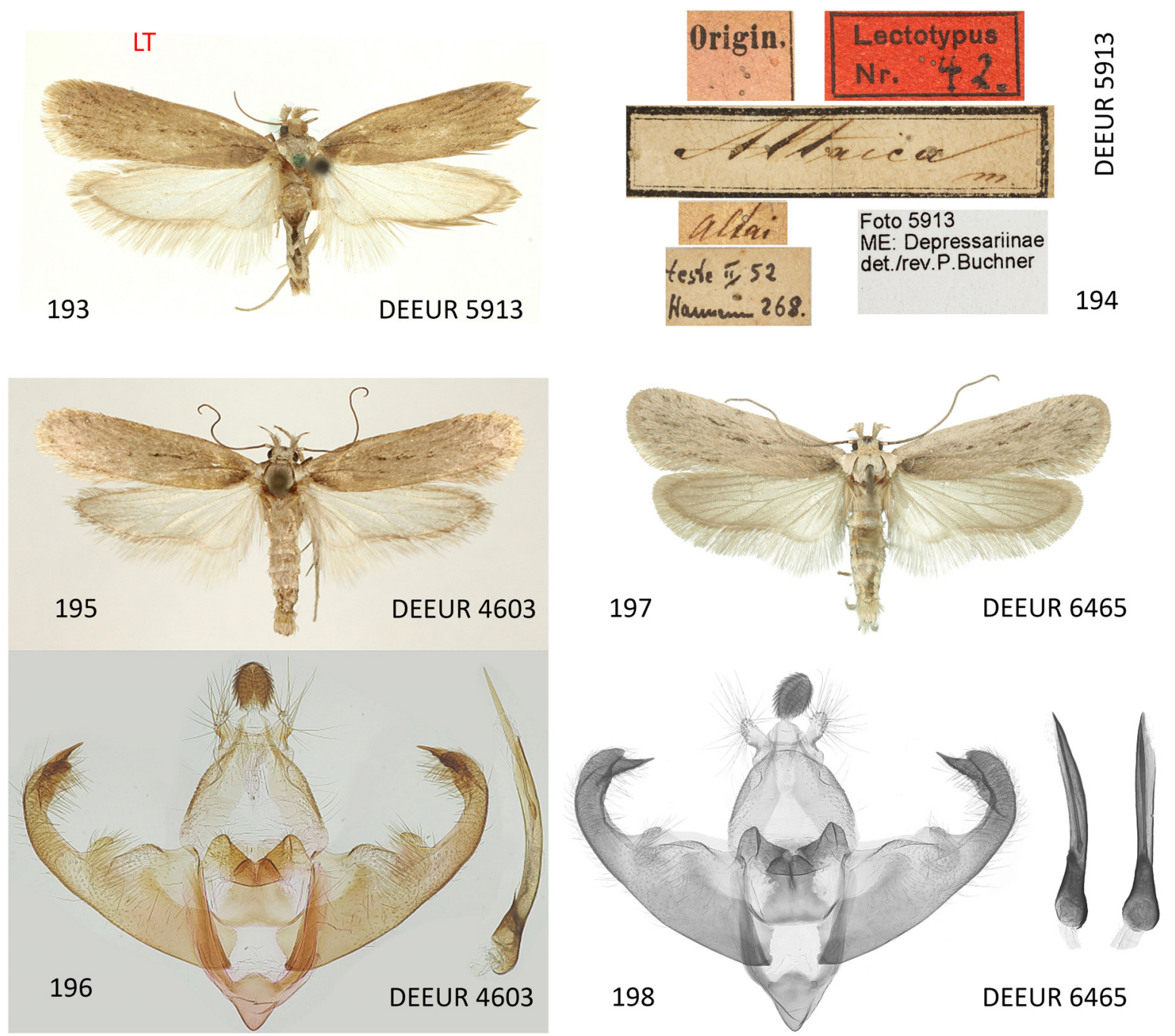

Figs 193-198. Depressaria altaica Zeller, 1854. 193-194 - lectotype: 193 - specimen; 194 - labels. 195-198 - Russia, S Ural. 195, 198 - habitus; 196, 198 - male genitalia.
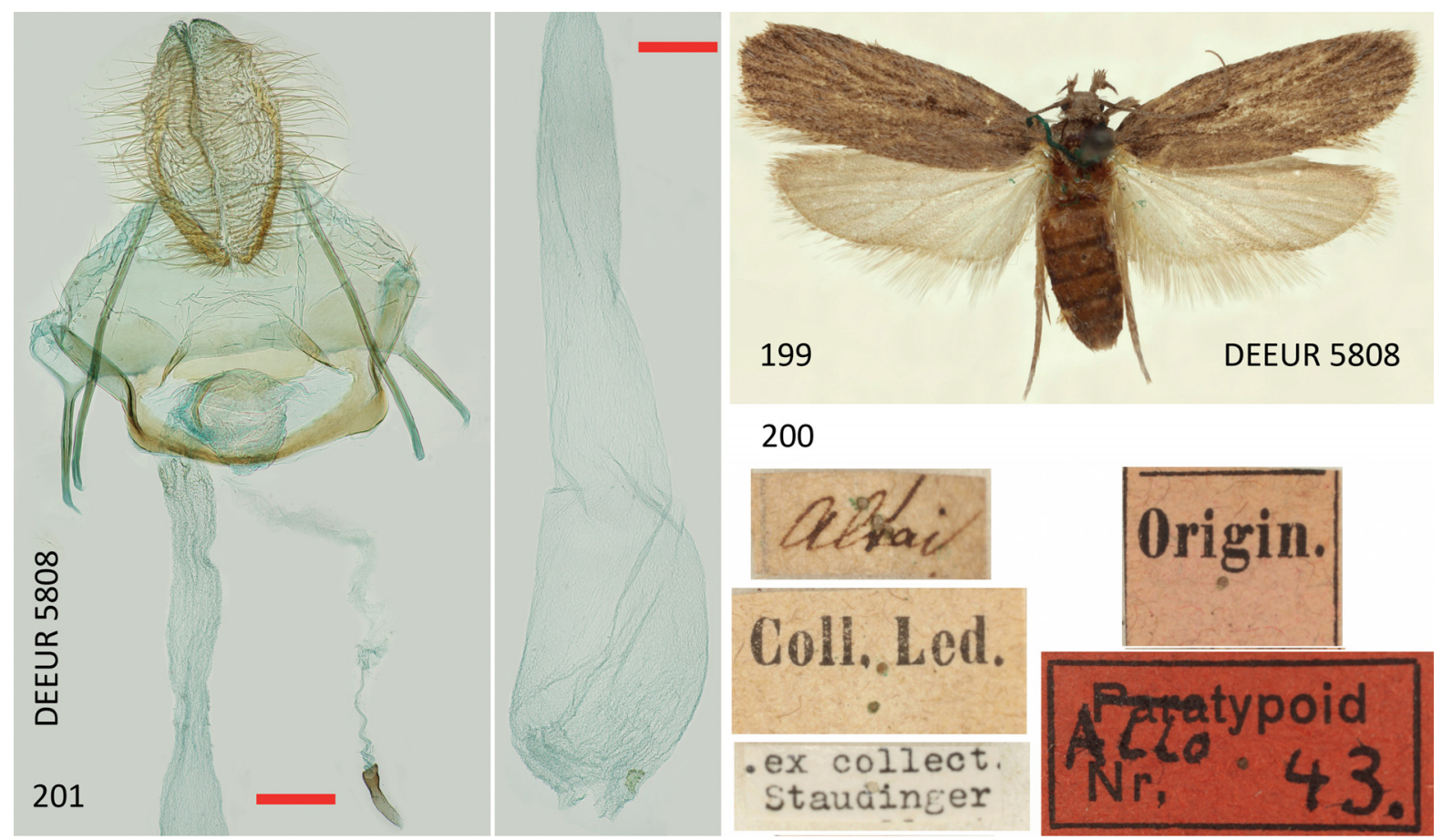

200

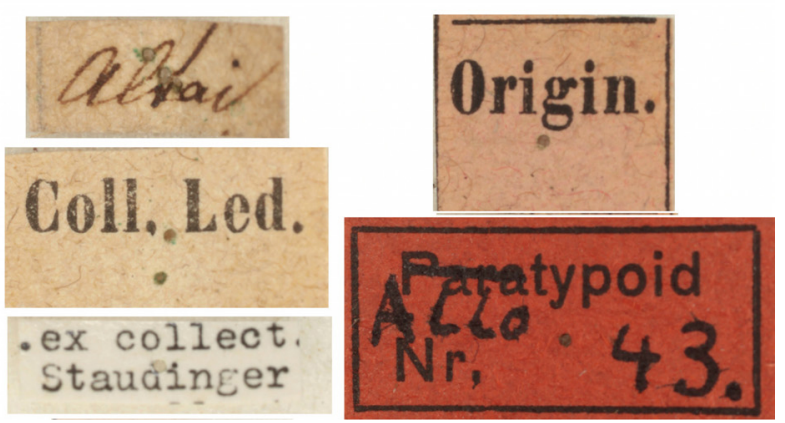

Figs 199-201. Depressaria schaidurovi Lvovsky, 1981, paralectotype of D. altaica, Kazakhstan, Altai Mts., without further collecting data (ZMHB); 199 - imago; 200 - labels; 201 - female genitalia. 
Table 4. An updated checklist of Depressariidae recorded in the Altai Republic with references to the first records. The classification and nomenclature follow Lvovsky (2008). New species for Russia are marked with an asterisk (*). Species endemic for the Russian Altai Mountains are marked with an exclamation mark (!).

\begin{tabular}{|c|c|}
\hline Species & References \\
\hline $\begin{array}{l}\text { Levipalpus hepatariella (Lienig \& Zeller, } \\
1846 \text { ) }\end{array}$ & HuEMER et al. (2017) \\
\hline Exaeretia allisella Stainton, 1849 & this paper \\
\hline Exaeretia indubitatella (Hannemann, 1971) & LVOVSKY (2013) \\
\hline Exaeretia lepidella (Christoph, 1872) & LVOVSKY (2008) \\
\hline $\begin{array}{l}\text { Exaeretia lvovskyi Buchner, Junnilainen \& } \\
\text { Nupponen, } 2019\end{array}$ & BUCHNER et al. (2019) \\
\hline Exaeretia mongolicella (Christoph, 1882) & LVOVSKY (2008) \\
\hline Exaeretia nebulosella (Caradja, 1920) & Huemer et al. (2017) \\
\hline Agonopterix abditella Hannemann, 1959 & Huemer et al. (2017) \\
\hline Agonopterix agyrella (Rebel, 1917)2) & LVOVSKY (2008) \\
\hline Agonopterix alstromeriana (Clerck, 1759) & LVOVSKY (2008) \\
\hline Agonopterix angelicella (Hübner, [1813]) & LVOVSKY (2008) \\
\hline Agonopterix anticella (Erschoff, 1877) & this paper \\
\hline $\begin{array}{l}\text { Agonopterix arenella ([Denis \& Schiffer- } \\
\text { müller], 1775) }\end{array}$ & LVOVsKY (2008) \\
\hline Agonopterix bipunctosa (Curtis, 1850) & this paper \\
\hline Agonopterix broennoeensis (Strand, 1920) & Huemer et al. (2017) \\
\hline Agonopterix conterminella (Zeller, 1839) & LvovsKy (2008) \\
\hline $\begin{array}{l}\text { Agonopterix kaekeritziana (Linnaeus, } \\
\text { 1767) }\end{array}$ & HUEMER et al. (2017) \\
\hline *Agonopterix kyzyltashensis sp. nov. & this paper \\
\hline
\end{tabular}

\begin{tabular}{|c|c|}
\hline Species & References \\
\hline Agonopterix pallorella (Zeller, 1839) & LvovsKy (2008) \\
\hline $\begin{array}{l}\text { Agonopterix putridella (Denis \& Schiffer- } \\
\text { müller, 1775) }\end{array}$ & this paper \\
\hline Agonopterix rimulella (Caradja, 1920) ${ }^{1)}$ & this paper \\
\hline Agonopterix sinevi Lvovsky, 1984 & LVOVSKY (2008) \\
\hline *Agonopterix ustjuzhanini sp. nov. ${ }^{3)}$ & this paper \\
\hline Depressaria hystricella Möschler, 1860 & LvovsKy (2008) \\
\hline $\begin{array}{l}\text { Depressaria absynthiella Herrich-Schäffer, } \\
1865\end{array}$ & LVOVSKY (2008) \\
\hline Depressaria artemisiae Nickerl, 1864 & LVOVSKY (2008) \\
\hline Depressaria atrostrigella Clarke, 1941 & LVOVSKY (2006) \\
\hline Depressaria badiella (Hübner, 1796) & LvovsKy (2008) \\
\hline Depressaria depressana (Fabricius, 1775) & LvovsKy (2008) \\
\hline Depressaria filipjevi Lvovsky, 1981 & LVOVSKY (2008) \\
\hline Depressaria falkovitshi Lvovsky, 1990 & this paper \\
\hline $\begin{array}{l}\text { Depressaria fuscovirgatella Hannemann, } \\
1967\end{array}$ & this paper \\
\hline Depressaria libanotidella Schläger, 1848 & this paper \\
\hline Depressaria nemolella Svensson, 1982 & HUEMER et al. (2017) \\
\hline $\begin{array}{l}\text { *!Depressaria paraleucocephala } \\
\text { sp. nov. }\end{array}$ & this paper \\
\hline Depressaria sibirella Lvovsky, 1981 & this paper \\
\hline
\end{tabular}

Notes. ${ }^{1)}$ in Huemer et al. (2017) as Depressaria sp.; ${ }^{2)}$ in HuEmer et al. (2017) as Agonopterix sp. 1; ${ }^{3)}$ in HuEmer et al. (2017) as Agonopterix sp. 2.

Ust-Bukhtarminsk (LEDERER 1855, cf. also VOLYNKIN \& YAKOVLEV 2015). Type series according to the original description contains two males and one female, and Zeller explicitly presents their deposition in the "Mus[eum]. Lederer" (ZELLER 1854), which means that the type material stayed deposited in Julius Lederer's collection at that time. At present, Lederer's collection is part of Microlepidoptera collection in ZMHB, and two types of $D$. altaica were found there: one male designated as lectotype by J. Hannemann (Hannemann 1953) (Fig. 193) and one female labeled by Hannemann as "allotypoid" (Figs 199-201); the third type is most probably lost. Both types have a locality label only with the name "Altai", handwritten by Lederer (Fig. 194) (the handwriting was compared with labels below Lederer's types, cf. also VolYNKIn \& YAKOvLEv 2015). This locality was published by ZeLLer (1854), and later incorrectly assigned to the Russian Altai (LvOvSKY 1981).

The lectotype was dissected by Hannemann and the drawing of its genitalia was published under the number "Lectotypus Nr. 42" (Hannemann 1953). The female was found undissected by the first author of this paper; subsequently it was dissected (Figs 199-201) and also barcoded (sample ID MFN-29197-H10). Surprisingly the result did not correspond with genetical data of the male collected in southern Ural (Fig. 195, material cited above) while its genitalia (Figs 196) fully fit the lectotype. Genitalia of the female paralectotype ("Allotypoid 43") correspond with Depressaria schaidurovi Lvovsky, 1981 according to the characters on female genitalia published by Lvovsky (2004).

Therefore, the type series of $D$. altaica consists of two different species, both undescribed before 1854. Hannemann's designation of the male as the lectotype defined the present concept of $D$. altaica Zeller, 1854. It belongs to the $D$. discipunctella / D. veneficella species group according to the male genitalia and genetical data, female of this species remains unknown. The female paralectotype belongs to D. schaidurovi described by LvovsKY (1981).

\section{Depressaria schaidurovi Lvovsky, 1981 (Figs 199-201)}

Material examined. KAZAKHSTAN: Altai, without date, 1 (Barcode MFN-29197-H10), A. Kindermann leg., ex. coll. J. Lederer [labeled as “Allotypoid 43", actually paralectotype of D. altaica] (ZMHB); 1 , , Altai, without date, ex coll. P. C. Zeller, ex coll. T. Walsingham (B.M. 1910427) [stored as unidentified specimen with code NHMUK010219624] (NHMUK).

Molecular data. BIN BOLD was not assigned $(n=2,0$ public, 0 from Altai). The specimen was processed with the NGS-protocol.

Distribution. Kazakhstan (Lvovsky 1981, 1984).

Remark. Depressaria schaidurovi was described on the basis of one male collected near Almaty (previously Alma-Ata) in Kazakhstan (Lvovsky 1981). Later, the female genitalia were figured by Lvovsky (2004), based on a specimen also found in SE Kazakhstan. Depressaria 

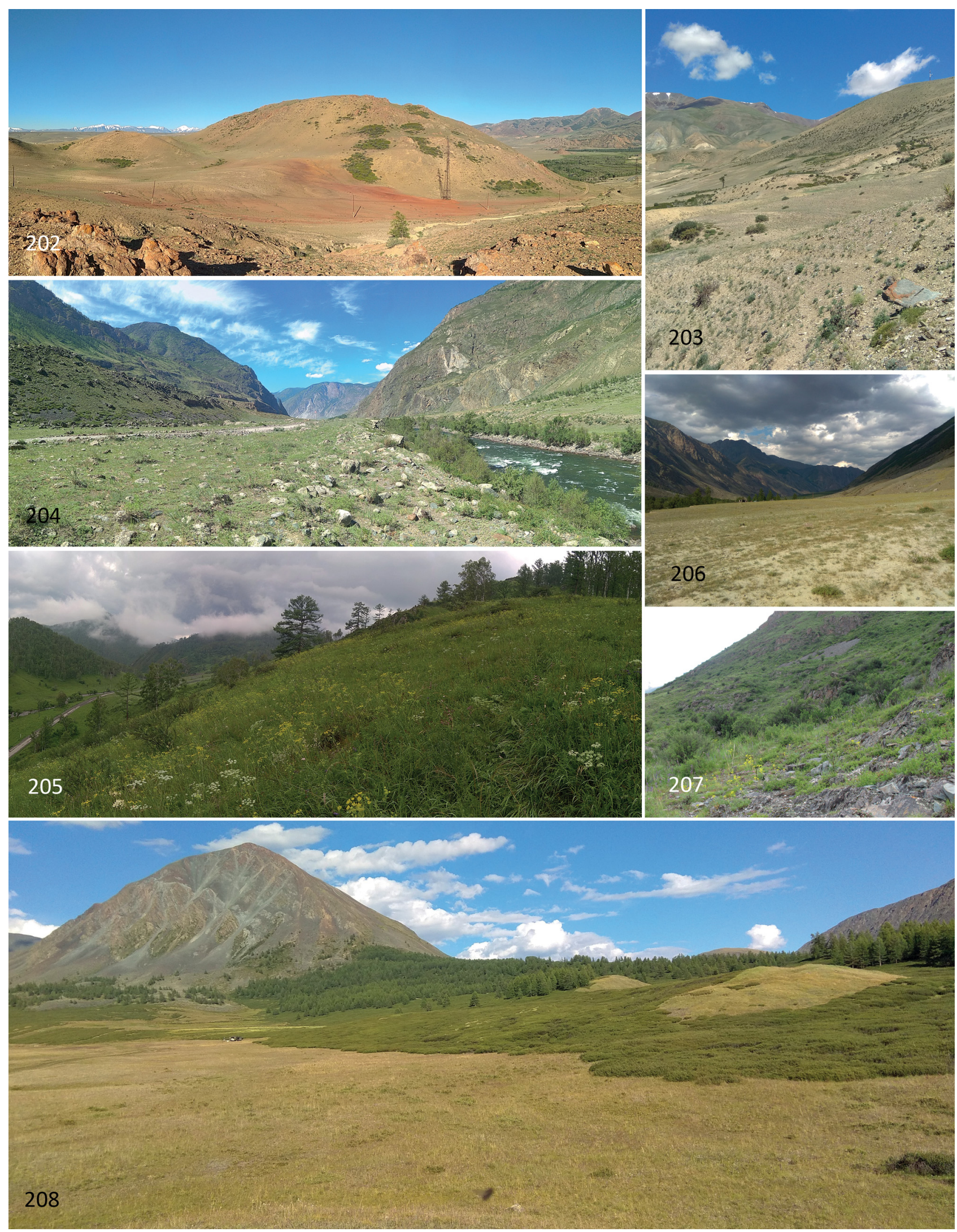

Figs 202-208. Habitats of the newly described species, Russia, Altai Mts. 202-203 - Krasnaya Gorka near Chagan Uzun, habitat of Agonopterix kyzyltashensis sp. nov.: 204 - Chulyshman valley, habitat of A. ustjuzhanini sp. nov. and Depressaria paraleucocephala sp. nov.; 205 - Cherga, habitat of A. ustjuzhanini sp. nov.; 206 - steppe near the confluence of Argut and Karagem rivers, habitat of Depressaria paraleucocephala sp. nov.; 207 - rocky steppe near Aktash vill., habitat of A. ustjuzhanini sp. nov.; 208 - mountain steppe near Dzhazator, habitat of A. ustjuzhanini sp. nov. 
schaidurovi is closely related to D. ruticola Christoph, 1873 based on genitalia, which is supported by molecular data, but there is no closer relationship to the D. discipunctella / D. veneficella species group.

\section{Acknowledgements}

The authors are very indebted to Jitka Ansari (London, United Kingdom) and Martin Corley (Faringdon, UK) for improvements and corrections of English. We also thank both reviewers, Martin Corley and Sergey Sinev, for their valuable comments. Ivo Dvořák (Jihlava, Czech Republic), Marek Dvořák (Smrčná, Czech Republic), Peter Huemer (Innsbruck, Austria), Christian Wieser (Klagenfurt, Austria), and Kari Nupponen (Espoo, Finland) are thanked for providing study material. Moreover, Kari Nupponen kindly provided the barcode data of Depressaria altaica for our comparison with $D$. schaidurovi. The first author is simultanously indebted to all private collectors and curators of the named institutions for the possibility to study the collections under their care. Jan Sumpich is very grateful to Petr Kment for significant support in context of DNA barcoding of moths. We also thank Dominik Vondráček (Prague, Czech Republic) who helped us with the barcoding and adjustment of the final text devoted to genetical data. The work of Jan Šmpich was financially supported by the Ministry of Culture of the Czech Republic (DKRVO 2019-2023/5.I.b, National Museum, 00023272).

\section{References}

BIDZILYA O. V., BUDASHKIN YU. I., KLYUCHKO Z. F. \& KOSTJUK I. YU. 2002: A contribution to the knowledge of the Lepidoptera fauna of the Ukok plateau in south-eastern Altai, Russia. Entomofauna, Zeitschrift für Entomologie 23: 201-220.

BUCHNER P. 2017: Faunistic records of Depressariidae (Lepidoptera, Gelechioidea) from Turkey - a result of studies for "Microlepidoptera of Europe: Depressariinae". CESA News 134: 1-34.

BUCHNER P., JUNNILAINEN J. \& NUPPONEN K. 2019: Agonopterix sideensis from Turkey and Exaeretia lvovskyi from Russia, two new species of Depressariidae (Lepidoptera) from the Palaearctic region, and the transfer of Exaeretia montuosella (Hannemann, 1976) into the genus Agonopterix Hübner, [1825]. Centre for Entomological Studies Ankara Miscellaneous Papers 178: 1-26.

EDGAR R. C. 2004: MUSCLE: multiple sequence alignment with high accuracy and high throughput. Nucleic Acids Research 32(5): 1792-1797.

HANNEMANN H. J. 1953: Natürliche Gruppierung der europäischen Arten der Gattung Depressaria s. 1. (Lep. Oecophoridae). Mitteilungen aus den Zoologischen Museum in Berlin 29(2): 269-373.

HANNEMANN H. J. 1958: Die Eingruppierung weiterer Depressarien nach dem Bau ihrer Kopulationsorgane, Teil 2 (Lep. Oecophoridae). Deutsche Entomologische Zeitschrift, Neue Folge 5: 456-465.

HANNEMANN H. J. 1990: Neue Depressarien (Lep. Oecophoridae). Deutsche Entomologische Zeitschrift, Neue Folge 37: 137-144.

HEIKKILÄ M., MUTANEN M., KEKKONEN M. \& KAILA L. 2014: Morphology reinforces proposed molecular phylogenetic affinities: a revised classification for Gelechioidea (Lepidoptera). Cladistics 30: $563-589$.

HUEMER P., WIESER C., WIESMAIR B., SINEV S. YU., WIESER C. \& YAKOVLEV R. V. 2017: Schmetterlinge (Lepidoptera) des AltaiGebirges (Südsibirien, Russland) - Eindrücke einer internationalen Expedition im Spätsommer 2016. Carinthia II 207/127: 527-564.

KLIMESCH J. 1942: Über einige Microlepidopteren der alpinen Fels- und Schuttflora. Tafel XII. Zeitschrift des Wiener Entomologen Vereins 27: $145-157$.
KUMAR S., STECHER G., LI M., KNYAZ C. \& TAMURA K. 2018: MEGA X: Molecular Evolutionary Genetics Analysis across computing platforms. Molecular Biology and Evolution 35: 1547-1549.

LANDRY J.-F., NAZARI V., WAARD J. R. DE, MUTANEN M., LOPEZ-VAARMONDE C., HUEMER P. \& HEBERT P. D. N. 2013: Shared but overlooked: 30 species of Holarctic Microlepidoptera revealed by DNA barcodes and morphology. Zootaxa 3794(1): 1-93.

LEDERER J. 1855: Weiterer Beitrag zur Schmetterlings-Fauna des Altaigebirges in Sibirien. Verhandlungen des Zoologisch-Botanischen Vereins in Wien 5: 97-120.

LIU S. \& WANG S. 2010: One new species and three newly recorded species of the genus Exaeretia Stainton, 1849 (Lepidoptera: Elachistidae: Depressariinae) from China. Zootaxa 2444: 45-50.

LVOVSKY A. L. 1981: New species of the broad-winged moths of the genus Depressaria Hw. (Lepidoptera, Oecophoridae) of the fauna of the USSR. Trudy Zoologicheskogo Instituta Asiatskoy Chasti SSSR 103: 73-83 (in Russian).

LVOVSKY A. L. 1984: New species of the broad-winged moths (Lepidoptera, Oecophoridae) of the fauna of the USSR. Proceedings of the Zoological Institute of the USSR Academy of Sciences 122: 87-93 (in Russian)

LVOVSKY A. L. 2001: A review of the flat moths of the genus Agonoperix Hbn. (Lepidoptera, Depressariidae) from the fauna of Russia. Proceedings of the Zoological Institute of the Russian Academy of Sciences 291: 47-100 (in Russian, English summary).

LVOVSKY A. L. 2004: A review of the flat-moth genus Depressaria Haworth, 1811 (Lepidoptera, Depressariidae) of the fauna of Russia and neighbouring countries. II. Entomologicheskoe Obozrenie 83: 190-213 (in Russian).

LVOVSKY A. L. 2006: Check-list of the broad-winged and flat moths (Lepidoptera: Oecophoridae, Chimabachidae, Amphisbatidae, Depressariidae) of the fauna of Russia and adjacent countries. Proceedings of the Zoological Institute Russian Academy of Sciences 307: 1-119 (in Russian).

LVOVSKY A. L. 2008: Depressariidae. Pp. 53-57. In: SINEV S. Yu. (ed.): Catalogue of the Lepidoptera of Russia. KMK Scientific Press Ltd., St. Petersburg, Moscow, 421 pp (in Russian).

LVOVSKY A. L. 2013: A review of flat moths of the genus Exaeretia Stainton, 1849 (Lepidoptera, Depressariidae) of the fauna of Russia and neighbouring countries. Entomologicheskoe Obozrenie 92: 780-801 (in Russian).

LVOVSKY A. L. \& STANESCU M. 2019: Taxonomic notes on five species of the family Depressariidae (Lepidoptera: Gelechioidea), described by Aristide Caradja from the Russian Far East. Zoosystematica Rossica 28(1): 251-257.

MUTANEN M., HAUSMANN A., HEBERT P. D. N., LANDRY J.-F., WAARD J. R. DE \& HUEMER P. 2012: Allopatry as a Gordian knot for taxonomists: Patterns of DNA barcode divergence in Arctic-Alpine Lepidoptera. PLOS ONE 7(10)(e47214): 1-9.

RATNASINGHAM S. \& HEBERT P. D. N. 2007: BOLD: The Barcode of Life Data System (http: //www.barcodinglife.org). Molecular Ecology Notes 7: 355-364.

RATNASINGHAM S. \& HEBERT P. D. N. 2013: A DNA-based registry for all animal species: the Barcode Index Number (BIN) system. PLoS ONE 8(8)(e66213): 1-16.

REBEL H. 1901: Catalog der Lepidopteren des palaearctischen Faunengebietes. II. Theil: Famil. Pyralidae-Micropterygidae. R. Friedländer \& Sohn, Berlin, 368 pp.

ROBINSON G. S. 1976: The Preparation of slides of Lepidoptera genitalia with special reference to the Microlepidoptera. Entomologist's Gazette 27: 127-132.

RYMARCZYK F., DUTHEIL M. \& NEL J. 2013: Agonopterix feruliphila (Millière, 1866), stat. rest., Agonopterix silerella (Stainton, 1865) en France et description de deux nouvelles espèces, Agonopterix orophilella $\mathrm{sp}$. nov. et $\mathrm{A}$. centaureivora sp. nov. $2 \mathrm{e}$ contribution à la connaissance des Depressarinae de France (Lep. Elachistidae: Depressariinae). Oreina 21: 13-24.

SINEV S. Yu., BARYSHNIKOVA S. V., LVOVSKY A. L., ANIKIN V. V. \& ZOLOTUHIN V. V. 2017: Volga-Ural Microlepidoptera described by E. Eversmann. Proceedings of the Museum Witt Munich 7: $374-379$. 
SOHN J.-C., REGIER J. C., MITTER C., ADAMSKI D., LANDRY J.-F., HEIKKILÄ M., PARK K., HARRISON T., MITTER K. T., ZWICK A., KAWAHARA A. Y., CHO S., CUMMINGS M. P. \& SCHMITZ P. 2016: Phylogeny and feeding trait evolution of the mega-diverse Gelechioidea (Lepidoptera: Obtectomera): New insight from 19 nuclear genes. Systematic Entomology 41(1): 1-21.

TAMURA K. 1992: Estimation of the number of nucleotide substitutions when there are strong transition-transversion and $\mathrm{G}+\mathrm{C}$-content biases. Molecular Biology and Evolution 9: 678-687.
VOLYNKIN A. V. \& YAKOVLEV R. V. 2015: Correct authorship of taxa of Lepidoptera, described in publications by Julius Lederer in 1853 and 1855 from Western Altai (Insecta: Lepidoptera). SHILAP Revista de Lepidopterologia 43: 673-681.

ZELLER P. C. 1854: Die Depressarien und einige nahe stehenden Gattungen. Linnaea Entomologica: Zeitschrift Herausgegeben von dem Entomologischen Vereine in Stettin 9: 189-403. 